\title{
THE LONDON MOSQUE FUND
}

\section{A Meeting of the Executive Committee of the London Mosque Fund was held at the Gaxton Hall on 13 December 19 IO $^{2}$}

\section{Present:}

The Chairman [Syed Ameer Ali*]

Sir Theodore Morison K.C.I.E.*3

Khalil Khalid Bey*

Hon A.M. Jeevanjee*

Mr C.A. Latif*

Mr A.S.M. Anik*

Mr M.T. Kaderbhoy*

I. The Chairman proposed that His Excellency the Persian Minister ${ }^{4}$ be invited to be a Member of the Executive Committee

The Motion was carried unanimously.

2. The Draft of the circular letter proposed to be issued by the Chairman to prominent people in Turkey, Persia, India and British Possessions generally was read and was carried with one amendment proposed by Khalil Khalid Bey, Esq, and seconded by Sir Theodore Morison, to the effect that the words "steps have already been taken

${ }^{\text {I}}$ Caxton Hall, located on the corner of Caxton Street and Palmer Street, London SWI, was a venue often used by Muslim groups in London for formal gatherings. Designed by Lee and Smith between I878 and I882, it is today listed at Grade II, primarily for its historical associations. Originally built as Westminster Town Hall, it was then used as a registry office until I979. Its historical associations include the Suffragette movement, speeches delivered by Churchill during the Second World War, and various society weddings.

${ }^{2}$ On 9 November I9Io a public meeting was called by Syed Ameer Ali at the Ritz Hotel in London to discuss the feasibility of constructing a mosque and an Islamic cultural centre in London. Sir Sultan Mohammad Shah Aga Khan took the chair. It was resolved to establish a fund with the purpose of implementing such a project. Sir Ernest Hotson (Hon. Secretary of the LMF) refers to this meeting in his address at the inauguration of the East London Mosque and Islamic Culture Centre on i August 194I. See BL, IOR, L/P\&J/I2/468.

${ }^{3}$ These minutes were recorded at the second meeting of the Executive Committee of the LMF, held on I3 $_{3}$ December I9Io under the chairmanship of Sir Theodore Morison.

${ }^{4}$ Official of the Persian Embassy in London. Probably Mirza Mehdi Khan Mushir-ulMulk (see n. 5). 
to draw attention to the scheme in Constantinople" be inserted in the Draft.

The Chairman was authorized to issue the circular letter under his own signature.

\section{A meeting of the Executive Committee of the London Mosque Fund was held on Monday 20 March 191 I, at 17 Hobart Place}

Present:

The Rt Hon Syed Ameer Ali (Chairman)

His Excellency the Persian Minister ${ }^{5}$

Sir William Bull, M.P.*

Mirza Abbas Ali Baig Esq.*

Mundji Fikri Bey*

Major Syed Hassan Bilgrami*

Mr C.A. Latif

Reouf Ahmed Bey

Mr A.S.M. Anik

Mirza Abdul Ghuffar Khan ${ }^{6}$

Md. Ali Chewky Bey

Mr M.T. Kaderbhoy

The Minutes of the last meeting were read and confirmed.

The Accounts were submitted, examined and passed.

Sir William Bull suggested that an enquiry might be made from the Russian Embassy as to the exact area of the mosque at St. Petersburg. $\mathrm{He}$ also suggested inviting Sir Lawrence Gomme* and Sir Edwin Cornwall* to join the General Committee. It was agreed.

The Chairman brought to the notice of the Committee that a site in Westminster was offered to the Committee for purchase but it was considered as rather too early to go into the matter.

The site proposed by Mr Latif was also considered.

${ }^{5}$ The Persian Minister in London was Mirza Mehdi Khan Mushir-ul-Mulk. See Sir Denis Wright, 'The Iran Society: the first sixty five years: I935-2000', http:/ /www.iransociety.org/ sixtyfive_I.htm (accessed 25 November 2009).

${ }^{6}$ Mirza Abdul Ghuffar Khan was the Persian Consul in London. 
Sir William Bull said it would not be a capital site. The site must be in the centre of the Empire.

The County Council would be sympathetic as regards the site near the Kingsway and that a site might be had on the River.

Several other sites were suggested but it was finally resolved that when the Project has made further advance a small Committee should be appointed to go into the question thoroughly as the Mosque was being built for all times and it must be commensurate with the dignity of Islam.

The drafting of the other letters and appeals was left in the hands of the Chairman and Mr Baig.

The letter received from the Bank of England was read by the Chairman.

The Draft rules of procedure for carrying on the work by the Executive Committee were adopted.

The question of the appointment of Trustees was considered - The Chairman said the Ottoman Empire ought to be represented by her Consul-General for the time being. The proposal was unanimously adopted.

His Excellency the Persian Minister proposed His Excellency Sadighus-Saltanah* to represent Persia on the Board of Trustees. It was unanimously adopted.

The Chairman proposed Mr Abbas Ali Baig as one of the Trustees for India. It was unanimously adopted.

Mr Abbas Ali Baig proposed The Right Hon Syed Ameer Ali as another Trustee for India. It was unanimously adopted.

The Chairman proposed His Highness the Aga Khan, ${ }^{* 7}$ Lord Ampthill* and Lord Rothschild* as the remaining Trustees. The resolution was unanimously adopted.

It was further resolved that should Lord Rothschild not accept the office, Sir Ernest Cassel ${ }^{8}$ be approached.

It was resolved that at least two thirds of the Trustees must be Mohammadans.

\footnotetext{
${ }^{7}$ Sir Sultan Mahomed Shah Aga Khan.

${ }^{8}$ The well-known banker, born of Jewish parents, who acted as financial advisor to King Edward VII.
} 
Finally the Committee adopted the following names for the office of Trustees:

I. His Highness the Aga Khan

2. The Rt Hon Lord Ampthill

3. The Rt Hon Lord Rothschild

4. The Rt Hon Syed Ameer Ali

5. Mirza Abbas Ali Baig

6. Mundji Fikri Bey (Imperial Ottoman Consul-General)

7. His Excellency Sadigh-us-Saltanah ${ }^{* 9}$

The Secretary to the Board of Trustees to be Mr C.A. Latif

The committee authorized $\mathrm{Mr}$ Ameer Ali to invite Lord Rothschild and Lord Ampthill to accept the Trusteeship of the Fund.

It was resolved that the signatures of two Trustees countersigned by the Secretary should be sufficient on Cheques.

Mr Shairani* ${ }^{* 10}$ be made a Joint-Secretary assistant of the Mosque Committee.

That Mr Ameer Ali and Mr Abbas Ali be authorized to draw out an appeal to the nobles and notables of the Moslem world for Funds.

Employment of a clerk on Io/- [shillings] a week was sanctioned for the work of the Mosque Committee.

Confirmed: Ameer Ali Chairman 24 April I9I I

\section{A meeting of the Executive Committee of the London Mosque Fund was held at 17 Hobart Place, SW on Friday 7 April rgI I}

Present:

The Right Hon Syed Ameer Ali (in the Chair)

Sir William Bull, M.P.

Mr M. Abbas Ali Baig

Mirza Abdul Ghuffar Khan

M.A. Chewky Bey

\footnotetext{
${ }^{9}$ Mirza Abdul Ali Khan.

${ }^{\text {Io }}$ Hafi Mahmud Khan Shairani.
} 
Mr C.A. Latif

Major Syed Hassan Bilgrami

Mr A.S.M. Anik

Mr M.T. Kaderbhoy

The question of obtaining the gracious assent of His Majesty the King to give his name as Patron of the London Mosque Fund was discussed.

Resolved that the kind offer of Sir William Bull to informally sound the Secretary of State for India" whether his Lordship could see his way to advise His Majesty to that effect, be accepted.

Confirmed: Ameer Ali Chairman 24 April IgI I

\section{Rules of the Executive Committee}

I. At meetings of the Executive Committee the quorum shall consist of five members including the office bearers.

2. Meetings of the Executive Committee shall be convened at the discretion of the Chairman whenever there is any matter of sufficient importance for collective discussion and consideration.

3. Other matters, such as the election of members of the Executive Committee may be dealt with by correspondence.

4. The Executive Committee delegate to the Chairman full power and discretion to elect members on the General Committee, persons living outside London, and report the same at the next meeting of the Executive Committee.

5. All disbursements connected with the printing, typing and postage of letters shall be made by the Treasurer under the direction of the Chairman and the accounts of such disbursements shall be submitted by the Treasurer every three months to the Committee for being passed.

6. Save and except monies received by the Treasurer for preliminary expenses, he shall deposit forthwith on receipt in the Bank of England in the name of the Trustees of the London Mosque Fund, and any [sic] contributions or donation received by him for and on behalf of the Fund. The Treasurer shall be at liberty to keep monies received by him for preliminary expenses on his own responsibility at any Bank

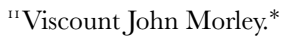


approved by him and to draw cheques thereon for disbursements connected with the carrying into execution of the Mosque Project.

7. All funds contributed towards the erection, maintenance and permanent endowment of the London Mosque, and any institutions annexed thereto, such as Library and Lecture rooms shall be vested in Trustees of whom at least two-thirds shall be Mussulmans.

Such Trustees shall be nominated at the meeting of the Executive Committee and reported at the next meeting of the General Committee.

\section{A meeting of the Executive Committee of the London Mosque Fund was held on Monday 4 December IgI I at: I7 Hobart Place, Grosvenor Gardens, SW at $4 \cdot 30 \mathrm{pm}$}

\section{Present:}

The Rt Hon Syed Ameer Ali

Sir Theodore Morison

M. Abbas Ali Baig, Esq

Mr W Bullock* (representing Sir William Bull)

Professor T.W. Arnold* (Sec.)

Mr A.S.M. Anik (Treas.)

The minutes of the last meeting were read and confirmed.

The Chairman placed before the Committee a letter received from Her Highness the Begum of Bhopal ${ }^{*_{22}}$ regarding the promised donation of $\mathcal{E}_{7}$, o0o towards the Mosque Fund.

The money was to be paid in instalments after the Delhi Durbar ${ }^{13}$ on the following two conditions:

(a) That sufficient money should be forthcoming for a hostel for students - attached to the Mosque with arrangements for Mohammedan diet.

(b) That all the money required for the mosque be forthcoming.

It was decided after some discussion that the secretary Professor Arnold should draft an answer accepting the conditions with

\footnotetext{
${ }^{12}$ Sultan Kaikhusrau Jahan Begum.

'3This Durbar (Persian term meaning 'royal court'), attended by King-Emperor George $\mathrm{V}$, was held in Delhi (India) in December I9I I to celebrate his coronation.
} 
reservations, and hoping that Her Highness would send the first instalment at her very early convenience.

The letter to be signed by the Chairman

Confirmed: Ameer Ali i7 April igi2

\section{A meeting of the Executive Committee of the London Mosque Fund was held on Monday 24 April igi I at the Rooms of the Royal Asiatic Society, 22 Albemarle Street W.}

Present:

The Rt. Hon. Sayed Ameer Ali (Chairman)

Mirza Abdul Ghuffar Khan

Reouf Ahmed Bey

Mohammed Ali Chewky Bey

Mr C.A. Latif

Prof. T.W. Arnold

Mr A.S.M. Anik

The minutes of the meeting of 20 March last and 7 April instant were read and confirmed.

The Chairman mentioned to the Committee the circumstances connected with Sir William Bull's approach to Lord Morley and its result.

It was proposed by Mirza Abdul Ghuffar that the subject should be treated as absolutely confidential so that it may not appear that the British Government was lacking in sympathy. ${ }^{14}$

Resolved that the best thanks of the Committee be conveyed to Sir William Bull for his kind trouble in the matter.

Resolved further that the Committee formally appeal for the patronage of His Imperial Majesty the Sultan.*

Mr Reouf Ahmed Bey kindly undertook to obtain His Majesty's gracious permission.

\footnotetext{
${ }^{14}$ This refers to the request that Lord Morley was asked to make for patronage by the King of the LMF.
} 
The Chairman stated that His Imperial Majesty the Shah* had already telegraphed through his Foreign Minister, that he had been graciously pleased to extend his patronage to the Fund.

The letter from the Persian Minister at Paris was read and the suggestion contained therein that an Advisory Committee - Comité d'Etude - should be formed, was considered.

It was resolved that the suggestion be adopted.

The following gentlemen were appointed to form members of the subCommittee to consider the question of a site and the models upon which the Mosque is to be built:

Mr Abdul Ghuffar Khan

Syed Mohd. Ali Chewky Bey

Professor Arnold

Mr Latif

The Chairman read the names of the gentlemen who had expressed their assent to join the General Committee.

The Chairman read the letters from Mr W. W. Barnes in reply to his letter inviting him to join the General Committee and asking for names and titles of the Sultans of the Malay Peninsula. ${ }^{15}$

The Chairman placed before the Committee the telegram of Halil Halid Bey. ${ }^{16}$

After some discussion it was resolved that the Secretary (Mr Latif) should write to $\mathrm{Mr}$ Halid that his telegram addressed to the Chairman saying that he had formed local committees in Egypt and that he was trying to do the same in Turkey, was considered by the Committee and that he was directed to request Mr Halid to place the secretary in communication with the secretaries of the committees which he had formed, and to inform them that all monies collected on behalf of the London Mosque Fund, should be remitted as soon as collected to the Bank of England, and that the names of the members of the different committees should be furnished to the secretary.

\footnotetext{
${ }^{15}$ The Malay Peninsula comprised the four Federated Malay States of Selangor, Perak, Negeri Sembilan, and Pahang, established by the British government in 1895, and the five Unfederated Malay States of Johor, Kedah, Kelantan, Perlis, and Terengganu, which came under British protection from 1909 under the Treaty of Bangkok.

${ }^{16}$ Khalil Khalid Bey, first mentioned in the Minutes on p. 81.
} 
The secretary was also requested to inform him that the trustees were appointed at a regularly convened meeting of the Executive Committee.

The Chairman brought before the Committee the letter written to him by Mr Anik (the Treasurer).

At the meeting held on 20 March it was proposed by Sir William Bull that Mr Latif as secretary should countersign the cheques and that Mr Anik should draw only cheques for preliminary expenses.

Mr Anik is of opinion that that makes his position on the Fund anomalous and that he would rather resign - he has all the settling of small accounts, everything is to be done by him. But his name is not to appear in the General Fund - he is, and has been, of great assistance to the committee.

Resolved that the Bank of England be informed that at a meeting of the Executive Committee held on 24 April at 22 Albemarle Street, it was decided that in addition to the counter-signature of the secretary there should be on the cheques drawn for and on behalf of the Fund, the counter-signature of the Honorary treasurer also, and that in the absence of one or other of them from England, one counter-signature should be sufficient.

Professor Arnold promised to give the full titles and designations of:

The Ameer of Afghanistan ${ }^{* 17}$

The Sultan of Zanzibar ${ }^{18}$

The Sultan of Lahej

And the names and titles of the Sultans of the Straits Settlements. ${ }^{19}$

Decided that in the appeals to the Princes the paper should have the heading - The London Mosque Fund - the names of Their Imperial Majesties the Sultan and the Shah, the Hon Presidents, the Presidents, the Chairman, the Treasurer and the Secretaries.

Resolved that Mr Shairani be appointed one of the assistant secretaries and be included in the Executive Committee.

\footnotetext{
${ }^{17}$ Habibullah Khan.

${ }^{18}$ Sultan Sayyid Khalifa bin Harub Al-Busaid became the 9th Sultan of Zanzibar (r. I9I II960) on the abdication due to illness of his brother-in-law Sayyid Ali bin Hamud Al-Busaid (r. I9O2-I9II).

${ }^{19}$ The name 'Straits Settlements' was given to the Crown Colony formed by the British possessions on or adjacent to the mainland of the Malay Peninsula. The Sultans were Muslims.
} 
Proposed by Mr Reouf Ahmed Bey that the number of the Executive Committee be limited to eighteen.

Considered desirable that all communications to the press be made by the Chairman.

Confirmed: Ameer Ali 8 May ı́ı I

\section{A Meeting of the Executive Committee of the London Mosque Fund was held on Monday 8 May I9I I at the Rooms of the Royal Asiatic Society, 22 Albermarle Street, at 3.30 p.m}

Present:

The Rt Hon Syed Ameer Ali (in the Chair)

Sir Theodore Morison

M. Abbas Ali Baig

Mirza Abdul Ghuffar Khan

Mohammed Ali Chewky Bey

Mundji Fikri Bey

Prof T.W. Arnold

Mr G.A. Latif

Mr A.S.M. Anik

Mr Khaderbhoy

Mr Shairani

The minutes of the last meeting were read and confirmed.

A message was received from Sir William Bull expressing his regret at not being able to be present.

The letter from the Chief Cashier of the Bank of England was placed before the Committee. The suggested form of resolution was considered and approved.

It was unanimously decided that the resolution passed at the meeting of the Executive Committee on 24 April be cancelled and the following substituted:

At a meeting of the Executive Committee of the London Mosque Fund held at 22 Albermarle Street, on Monday 8 May, it was resolved:

"That whenever possible, cheques drawn upon the account of 'The Rt Hon Lord Ampthill and Others' shall be countersigned by 
the Honorary Treasurer (Abdeali S. M. Anik Esq) as well as by the Honorary Secretary (C. Abdul Latif Esq), and, to provide for the absence of either of them from London, it was further resolved that the Bank of England be authorised to accept at any time the counter-signature of either the Honorary Secretary or the Honorary Treasurer alone".

The Chairman placed before the Committee a letter received from Mr Reouf Ahmed Bey, requesting that he might be authorized (so as to prevent possible misunderstanding) to form local committees in Constantinople.

The Chairman proposed that as Mr Reouf Ahmed Bey was a responsible and reliable person they should give him that authority.

Mundji Fikri Bey informed the Committee that a central committee had already been formed in Constantinople, and that possibly there was no necessity to charge Mr Reouf Ahmed Bey with the authority.

He also reported that Halil Halid Bey had been attacking him personally in reference to the Mosque Fund - It seemed to him most inconsistent, as they were working in the project as a body and not individually.

After some discussion it was unanimously approved that the Committee should authorize Mr Reouf Ahmed Bey to take such steps in conjunction with the Central Committee in Constantinople as may be deemed expedient to form local committees in the Provinces in Turkey.

The Committee also took note of the suggestion of Mr Reouf Ahmed Bey regarding communication to the newspapers that collections should be sent to the Bank of England.

Mundji Fikri Bey informed the Committee that the Central Committee at Constantinople had been formed to receive, in the first place, all contributions from the Provinces, and to send them direct to the Bank of England.

The Committee decided to request $\mathrm{Mr}$ Reouf Ahmed Bey to place himself in communication with the Central Committee at Constantinople formed under the Presidency of the Prince Imperial the Heir Apparent, ${ }^{20}$ and to act in co-operation with it.

\footnotetext{
${ }^{20}$ Mehmed VI Wahid ed-din (I86I-I926) succeeded Mehmed V Reshad as the 36 th and final Sultan of the Ottoman Empire, reigning from I9I8 to 1922.
} 
It was approved that Mr Chewky Bey should act as Secretary to the advisory sub-committee.

It was mentioned by the Chairman that the Shah had at once telegraphed his willingness to become a patron of the Fund.

The question of an appeal to the Amir ${ }^{21}$ was then discussed. The sense of the Committee was that an appeal should be made to His Majesty the Amir. There was some discussion as to whether he should be asked to extend his patronage along with their Imperial Majesties the Sultan and the Shah.

It was unanimously agreed that that should be deferred.

Decided that it was best not to attach to the Mosque the name of any individual donor.

The Chairman stated that Sir Frank Swettenham* had kindly assented to join the General Committee.

Mr W.W. Barnes the Colonial Secretary at Hong Kong also assented to become a member of the Committee.

Confirmed: Ameer Ali 2i July igi i.

\section{A meeting of the Executive Committee of the London Mosque Fund was held on Thursday 20 July IgII at 3 pm at 36 Queen's Gate Terrace S.W.}

Present:

The Rt Hon Syed Ammer Ali (in the Chair)

Sir William Bull MP

Mirza Abdul Ghuffar Khan

M Abbas Ali Baig

Halil Halid Bey

Professor Arnold

Mr Latif

Mr Anik

Mr Khaderbhoy

\footnotetext{
${ }^{21}$ Probably Habibullah Khan (I872-I9I9), the ruler (Amir, literally leader/commander/ ruler in Arabic) of Afghanistan from Igor until his assassination in I9I9.
} 
The minutes of the last meeting were read and confirmed.

The accounts up to date were submitted:

The Net Balance at Bank of England

The Net Balance at London, S. Western Bank

Total expenditure up to date

$\begin{array}{rrr}\underset{\mathrm{L}}{\mathrm{I} 2 \mathrm{I}} & \mathrm{s} & \mathrm{d} \\ 44 & \mathrm{I} & 5 \\ 60 & 7 & 6 \\ & 7 & 6\end{array}$

The accounts were unanimously passed.

The Chairman mentioned under the express condition that the matter should be kept strictly confidential and not to be published until sanction was received from Her Highness, that Her Highness the Begum of Bhopal had promised the sum of $\mathcal{E}_{7}$,0oo towards the Fund.

The Chairman informed the Committee that Mr Saiduddin of the Transvaal had written to him to say that collections were being made and that it was proposed to send I/5 of the total to the Mosque Fund and two thirds to the University Scheme and that they hoped to raise Ei,ooo.

Appeals had been sent to the Malayan Sultans signed both by $\mathrm{H} \mathrm{H}$ the Aga Khan and the Chairman, through Sir Frank Swettenham. The proposal of the Chairman that he should write to Mr Noordin asking him to visit and interest the Malayan Chiefs and magnates was unanimously approved.

Appeals had been sent to His Majesty the Amir and Their Highnesses the Sultan of Zanzibar, the Bey of Tunis ${ }^{22}$ and to Syed Khalifa of Zanzibar.

The Chairman mentioned that Raja Tassaduq Rasul* had remembered the appeal most sympathetically and had asked how much was required for carrying out the Project into execution. The Chairman suggested asking him for Rs. 50,000 - Sir Theodore Morison thought Rs. I00,000 would be better.

It was mentioned by the Chairman that $\mathrm{H} \mathrm{H}$ the Begum's great desire was to have a hostel annexed to the Mosque for the lodgement of students, and that His Highness the Aga Khan and he had accepted Her Highness' suggestion provided sufficient funds were forthcoming.

\footnotetext{
${ }^{22}$ Muhammad V an-Nasir (I855-I922) ruled Tunisia between I9o6 and I922.
} 
It was considered advisable to begin to ask for definite sums in the appeals.

Decided to ask Rs. 25,00o from the Divan of Palanpur ${ }^{23}$ and the same sum from Wazir Baharuddin Bhai.

Proposed by Mr Baig that the following gentlemen should be written to:

[in pencil] list to be inserted

The Chairman mentioned the receipt of a letter from the High Priest of the [illegible $]^{24}$ promising all the support and help in his power in furtherance of the Project but not desiring to appear on the Committee.

He had been asked again and it was mentioned to him that His Highness the Sheikh-ul-Islam ${ }^{25}$ and Their Holinesses the Chief Mujtahid of Ndjef and the Chief Mujtahid of Tehran had joined the Committee. ${ }^{26}$

Mr Halil Halid then laid the report of the work he had done in Egypt and Turkey before the Committee.

In the first place he reminded the Committee that at a meeting held at Caxton Hall on the i3 December i9io previous to his departure he had mentioned his intention of going to Egypt and Turkey for six weeks in order to work for the Fund there.

In Egypt he soon managed to interest and encourage the people by means of the Press. After which a local committee under the presidency of the late Riaz Pasha was formed with Mohamed Bey Salim as its secretary and himself as corresponding member.

It was decided both in Egypt and Turkey that no officials should become members of the committee. The following are the members of the committee in Egypt:

\footnotetext{
${ }^{23}$ Ruler of the princely state of Palanpur in western India.

${ }^{24}$ The writing in the Minutes here is not clear but it may well be a reference to the High Priest of the Bohras, a Muslim sect to be found in western India.

${ }^{25}$ The highest-ranking Muslim scholar officially appointed by the Caliph; the office of Sheikh-ul-Islam carried the authority to make binding religious pronouncements. For instance, on I4 November I9I4 during the First World War, Mustafa Hayri declared jihad against the Allies, calling on all Muslims to take up arms against them.

${ }^{26}$ The equivalent of the Sunni office of Sheikh-ul-Islam in the Shia tradition is the Mujtahid, among whom that of Ndjef (in Iraq) and that of Tehran (in Iran) traditionally assumed much authority.
} 
[no names provided in the Minutes]

After a period of five weeks they were able to hold a large meeting he himself giving lectures at various places on the Mosque and its great need. The collections at the time amounted to $£ 620$. Before he left Egypt the sum had increase by $£ 300$.

It had been strongly urged that an Egyptian should be placed on the London Committee.

In Turkey the work was considerably more difficult as the people there were not easily moved or persuaded. He therefore set about to obtain the assent of all the members of the Senate and to obtain an interview with $\mathrm{H} \mathrm{H}$ the Imperial Heir Apparent whom he begged to become the President of the Committee which they were about to form and he promised to do his best for them.

Mr Halil Halid mentioned that both in Egypt and Turkey the people wished to hold the contributions until the Project was fairly advanced, when they would communicate and then send the result to one of the papers that it might fully take up and explain the matter. The Syrians had taken up the matter and they were going to form local committees in Beirut. ${ }^{27}$ The progress was slow but the Project would be taken up later.

The Committee considered Mr Halil Halid's work satisfactory and a vote of thanks was accorded to him.

The Chairman wished to suggest the desirability of asking the secretaries of the different committees to communicate with the secretaries here so that there might be no disunity amongst the parties. It was proposed that their names should be handed to the secretaries here so that communication might be continued whilst Mr H Halid was away. During his absence he would be kept informed of all the proceedings.

Sir William Bull considered that the more the various parties were in touch with each other the better it would be for the prosecution of the work.

In reply to Sir William Bull's question as to his plans Mr Halil Halid said he would be going to Constantinople again but would be in touch with this country.

\footnotetext{
${ }^{27}$ Beirut was then part of Greater Syria, under Ottoman control. Lebanon eventually achieved independence in 1943.
} 
Sir William Bull considered that as $£$ I5, Ooo were now promised to the Fund the Egyptian committee ought to have no hesitation in making over the contributions collected by them. It was merely necessary to assure them of the extent of the progress.

Regarding the amount now at the Ottoman Bank Mr Halil Halid said the sum was $\mathcal{E}_{200^{28}}$ and that although he had written about its being transferred to the Bank of England he had heard that nothing could be done until October.

Sir Theodore Morison suggested that the Committee should mention to Mr Halil Halid that he should when he is there - and feels that the opportune time has arrived - inform the local committee that the money should be transferred as soon as possible to the proper Bank of the Fund. Sir Theodore Morison considered that Mr Halil Halid was a better judge of the people he had to deal with and would know exactly when to place the matter before them.

Mr Halil Halid said the people found it difficult to send small sums to the Bank in England.

Mr Abbas Ali Baig suggested that the money might be sent to the Ottoman Bank as a channel as it was a step which would console the people - eventually the monies would have to come to the Bank of England.

Sir William Bull asked in whose name the sum of $£ 200$ was - which is at the Ottoman Bank. Mr Halil Halid said the sum was in his name. The remainder being at the disposal of the committee at Constantinople. Mr Halil Halid thought it was in a bank.

The Committee thought it undesirable and most unsafe to keep the collections scattered in so many places.

Mr Halil Halid considered it too soon to communicate with the committees with reference to the money.

It was decided that the name of the secretary in Egypt should be ascertained from Mr Halil Halid and that he should be written to at once, but they should wait with regard to Constantinople.

Secretary of Mosque Fund

Mohammad Bey Salim

\footnotetext{
${ }^{28}$ There is a note in the margin of the Minutes about this, but its contents are illegible.
} 
I9 Shariah Banlak

Cairo

Confirmed: Ameer Ali Chairman 2i Sept rgi I

\section{A meeting of the Executive Committee of the London} Mosque Fund was held on Thursday 2 I September IgI I at $3.30 \mathrm{pm}$ at the Gaxton Hall Westminster SW

\section{Present:}

The Rt Hon Syed Ameer Ali (Chair)

His Excellency the Persian Minister

Sir William Bull

Mirza Abdul Ghuffar Khan

Reouf Ahmed Bey

Mohammed Ali Chewky Bey

Mr G. A. Latif

Mr A. S. M. Anik

The minutes of the last meeting were read and confirmed.

The Treasurer submitted the accounts:

The total amount up to date

Total expenditure

Amount in Bank of England

Amount in London South Western Bank

\begin{tabular}{|c|c|}
\hline E44273- & $9^{-}$ \\
\hline $\mathcal{E} \quad 75^{-}$ & $9^{-}$ \\
\hline $\mathrm{E}_{4} \mathrm{O} 67^{-}$ & $\mathrm{I}^{-}$ \\
\hline
\end{tabular}

The Treasurer pointed out that the money was lying idle at the Bank.

Sir William Bull considered it advisable that a portion of the money say $\mathcal{E}_{3}, 000$ should be placed on Deposit at once. He knew that the Bank of England accepted Deposits but he was not sure on what principle it was done.

It was resolved that a letter should be drafted by the Chairman in consultation with the Secretary and the Treasurer and sent to the Chief Cashier of the Bank of England to enquire on what principle the Bank received money on deposit and whether a separate deposit form for every succeeding deposit was used or whether the prior deposit was called in and a fresh receipt issued. 
The Chairman then brought to the notice of the Committee that with the exception of $f_{\mathrm{I}}, \mathrm{Ooo}$ no money had been received from Turkey whilst Persia had in comparison responded admirably.

India had it was true not done much but the hearts of the people waiting for the Durbar ${ }^{29}$ had not yet been touched. It was desirable therefore, and necessary to take some step with regard to Turkey. It was understood that a central committee existed in Constantinople but so far it had made no communication to this committee and except for the information given by Mr Halil Halid nothing was known.

The Secretary in Egypt he understood had been written to on two occasions but no reply had been received.

Mr Reouf Ahmed Bey said that $£ 5$ oo had been collected by the newspaper the "Sabah" "30 in Constantinople.

Mr Halil Halid said that that sum had been collected and that $£ 200$ was at the chief office of the Ottoman Bank in Constantinople in the name of the London Mosque Fund.

The "Sabah" held the remainder.

Mr Halil having given the address of the secretary in Constantinople, it was resolved that he should be written to at once on the subject and asked to place the London Committee in communication with the Central Fund.

The Chairman mentioned that local committees had been formed at all centres in Persia by high dignitaries who were in communication with the London Committee and he suggested that the same procedure should be adopted in Turkey and Egypt.

Reouf Ahmed Bey said that he would be going to Constantinople soon and would be glad to do all in his power in promoting the formation of local committees in the European Provinces.

Mr Halil Halid gave the following names of some of the members of the Turkish committee:

His Excellency Prince Said Pacha

His Excellency Ghazi Makhtar Bey (Vice President Senate)

His Excellency Sheriff Haider Bey (Senator)

Rafi Pacha

\footnotetext{
${ }^{29}$ Another reference to the I9I I Delhi Durbar.

${ }^{30}$ Peyam-Sabah (Morning Newes) was a mainstream, Constantinople-based, Ottoman-Turkish, daily newspaper.
} 
Riza Sulh Bey (Deputy for Beyrut)

Mufti Bey (Deputy for [illegible], Secretary of Committee)

The Chairman proposed the following gentlemen as members of the General Committee:

Tomail Abaza Pacha and Sounour Bey (Advocate at Cairo)

Approved by the Committee and duly elected.

The Chairman read a letter from Mr B.L Moseley referring to the membership and co-operation of Tomail Abaza Pacha and himself enclosing a cutting from the Egyptian Gazette (I9 August I9II) ${ }^{31}$ in which a statement made to a representative of the "Near East" ${ }^{2}$ by Halil Halid Bey was reproduced.

It was resolved that a letter should be written at once to the secretary of the Egyptian committee welcoming their valuable help as a subcommittee of the London Mosque Fund and telling them that in our judgement it was considered best that all funds collected on behalf of the London Mosque Project should be sent as soon as collected to the proper Bank of the Fund, the Bank of England.

The Chairman requested the sanction of the Committee for the purpose of having the English appeal to the Princes put into Arabic. Mirza Abdul Ghuffar Khan undertook the task.

With reference to the disbursements in Turkey and Egypt by Mr Halil Halid, the Committee considered that they had no right to dispose of money which had been given towards another object.

A letter received from Alladin Devjibhai of Bhavnagar, ${ }^{33}$ was read. The sense of the meeting was that the Chairman should reply to the letter personally.

A letter from Mr Zuhudurz Rahim Kalid was considered and the authority therein desired was sanctioned. A letter in reply was to be sent by the Chairman.

\footnotetext{
${ }^{31}$ The Egyptian Gazette, the Middle East's oldest English-language newspaper, first appeared on 26 January i88o. Founded by five Britons, it was produced in Alexandria as a fourpage weekly tabloid. See http://213.I58.I62.45/ egyptian/index.php?action=about_us (accessed Io January 20II). Its I9I issues are available at the British Library's Newspaper and Periodicals section, located at Colindale, London.

${ }^{32}$ Past issues of The Near East from I908 to 1925 are available at the British Library's Newspaper and Periodicals section, located at Colindale, London.

${ }^{33}$ The city of Bhavnagar, founded in $1723 \mathrm{CE}$, was the capital of Bhavnagar State, which was the first princely state to merge with independent India in 1948 .
} 
Mirza Abdul Ghuffar Khan undertook to write the letter to the Amir of Afghanistan asking him to become the Patron of the Fund.

Resolved by the Committee that the name of Mr M.T. Kaderbhoy be removed from the Executive Committee of the London Mosque Fund..$^{34}$

\section{A meeting of the Executive Committee of the London Mosque Fund was held on Monday 6 November rgi i at 17 Hobart Place, Grosvenor Gardens, W at 5 pm}

Present:

The Rt Hon Syed Ameer Ali

Mohammed Ali Chewky Bey

M. Abbas Ali Baig Esq

A.S.M. Anik Esq

Sir William Bull's representative

Sir William Bull expressed his regret at being unable to be present

The minutes were read and confirmed.

Mr Anik submitted the accounts which were duly passed. The total of donations from the 9 November igro to 3I October was $£ 4443^{-I} 4^{-2}$.

Expenditure of $\AA^{8} 5^{-8-2 .}$

The question of investing part of the money was discussed. After some consideration the following resolutions were unanimously passed:

I. Resolved that out of the sum of $£ 4273^{-12-2}$ standing to the credit of the Trustees of the London Mosque Fund in the Bank of England a sum of $£ 4000$ be invested forthwith in the $3 \frac{1}{2}$ Gold Loan of the Government of India, subject to the sanction of the Trustees.

\footnotetext{
${ }^{34}$ Most probably because Kaderbhoy had returned to India; it seems that he was still active in Muslim politics and in the All-India Muslim League - for instance, he was present at a meeting of its leaders at the law chambers of Muhammad Ali Jinnah (later first Governor-General of Pakistan) in Bombay on i9 March I9I4. See http://www.nihcr. edu.pk/Downloads/Chronology.pdf (accessed 27 November 2009).
} 
2. Resolved further that the Chairman be requested to communicate the resolution to the Trustees and obtain from them the necessary sanction.

Confirmed: Ameer $\mathrm{Ali}_{4}$ December igI I

\section{A meeting of the Executive Committee of the London Mosque Fund was held on Monday 4 December IgI I at: I7 Hobart Place, Grosvenor Gardens, S.W at $4 \cdot 3^{\circ} \mathbf{~ p m}$}

Present:

The Rt Hon Syed Ameer Ali

Sir Theodore Morison

M. Abbas Ali Baig, Esq

Mr W. Bullock (representing Sir William Bull)

Professor T.W. Arnold (Sec.)

Mr A.S.M. Anik (Treas.)

The minutes of the last meeting were read and confirmed.

The Chairman placed before the Committee a letter received from Her Highness the Begum of Bhopal regarding the promised donation of $£ 7,000$ towards the Mosque Fund.

The money was to be paid in instalments after the Delhi Durbar on the following two conditions:

(a) That sufficient money should be forthcoming for a hostel for students - attached to the Mosque with arrangements for Mohammedan diet.

(b) That all the money required for the mosque be forthcoming.

It was decided after some discussion that the secretary Professor Arnold should draft an answer accepting the conditions with reservations, and hoping that Her Highness would send the first instalment at her very early convenience.

The letter to be signed by the Chairman.

Confirmed: Ameer Ali I7 April ıgı2 


\section{A meeting of the Executive Committee of the London Mosque Fund was held on Wednesday April 17 I912 at 3.30 pm at 22 Albermarle Street SW}

\section{Present:}

The Right Hon Ameer Ali

Sir William Bull

Mr M. Abbas Ali Baig

Syed Mohd. Chewky Bey

Mr Bullock

The minutes of the previous meeting were read and confirmed.

A letter from Her Highness the Begum of Bhopal dated 8 February was read and discussed..$^{35}$

Mr Baig was requested to prepare a draft reply to be approved and signed by the Chairman.

Mr Baig gave a resume of the history of the Woking Mosque Endowment Fund ${ }^{36}$ and mentioned that with the consent of Mr Ameer Ali and Mr Arnold they with himself had been appointed Trustees of the Fund and it merely remained for the Committee to decide whether to take over the mosque or not.

Mr Baig stated further that the draft of agreement together with Title Deeds was at the Treasury Office. If the Committee agreed to take it over Mr Baig proposed that Mr Leitner ${ }^{37}$ should be asked to join the Committee.

The Ghairman proposed that the Committee should take over the Mosque and Institute. Unanimously approved.

Sir William Bull suggested that Trustees should arrange to entrust the Title-Deeds and Agreement to some Bank.

Mr Baig proposed that a tin safety box be purchased and that on it be put the names of the three Trustees and the words "Woking

\footnotetext{
${ }^{35}$ This letter is not available with the Minutes.

${ }^{36}$ The Woking Mosque Endowment Fund was set up by Gottleib Wilhelm Leitner.* For more details of developments at Woking, see M.P. Salamat, A Miracle at Woking: a history of the Shahjahan Mosque (Andover, 2008). See also http://www.wokingmuslim.org/ pers/dr_leitner.htm (accessed 27 November 2009).

${ }^{37}$ The reference here is to G.W. Leitner's only son, Henry (I869-I945).
} 
Endowment Trust" and that the same should be reported at the following meeting. Unanimously approved.

Mr Anik was asked to accept the Treasurership which he kindly consented to do.

Mr Leitner was unanimously elected a member of the Executive Committee.

Read and confirmed: Ameer Ali chairman

\section{A meeting of the Executive Committee of the London Mosque Fund was held on Tuesday I6 July IgI 2 at 3 pm at 2 I Gromwell Road, South Kensington}

\section{Present:}

The Rt Hon Ameer Ali

Professor T.W. Arnold

Mr A.S.M. Anik

Mr Shairani

The minutes of the last meeting were read and confirmed.

The Chairman proposed that Prof Arnold should be asked to undertake the office of Secretary to the Woking Endowment Trust. Unanimously carried.

Prof Arnold as Secretary of the Mosque Fund was requested to enquire from Mr Baig if the deeds of the Trust had been endorsed over by Mr Leitner to the Trustees and what steps still remained to be taken by the Mosque Fund Committee. Also to enquire whether it was not necessary to put someone in charge of the Mosque at Woking.

The President suggested that perhaps a number of gentlemen from the Mosque Committee might be able to visit the spot and decide what was to be done.

The Honorary Treasurer Mr Anik submitted his accounts:

Total amount received $\quad £ 4969-7-9$

Balance $\quad £ 4870-17-8$

Invested $\quad £ 4000$ 


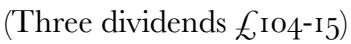

Balance at date:

$$
\text { £955-9-9 }
$$

It was decided that the sum of $£ 7$ oo out of the Balance should be invested.

Mr Anik was requested to enquire from Mr Hayes if he would undertake to audit the Mosque Fund Accounts.

Confirmed: Ameer Ali Chairman

\section{A meeting of the Executive Committee of the London Mosque Fund was held at 4I Sloane Street SW on Wednesday 30 April rgi3 at 5 pm}

Present:

The Rt Hon Ameer Ali (in the chair)

Mr Abdul Ghufar Khan

Professor T.W. Arnold

Mr C.A. Latif

Mr A.S.M. Anik

The minutes of the previous meeting were read and confirmed.

Woking Mosque: Mr Arnold reported in this connection that as desired he had made the necessary enquiries from Mr Baig who had informed him that no documents had so far been made over but that the matter was still in the hands of the lawyers.

The Treasurer then submitted the Financial Report up to date. This was approved..$^{3}$

The Committee confirmed the investment made by the Treasurer according to the decision arrived at by them at a previous meeting.

It was proposed that in view of the small sum necessary for every day expenses the sum of $£ 300$ out of the $£ 4$ I 7 standing to the credit of the current cash account should be invested.

\footnotetext{
$3^{8}$ No details of finances are included here in the Minutes.
} 
This was unanimously approved and $\mathrm{Mr}$ Anik was requested to take the matter in hand and he agreed to do so.

Circular letter: The President proposed that a circular letter should be issued explaining why no meetings had been held and no progress made. Professor Arnold undertook to draft the letter which was to be sent to the Trustees and all large subscribers.

Letter from the Begum

On the motion of the President seconded by Mr Abdul Ghaffar Khan it was resolved that Mr Arnold as secretary be requested to communicate with $\mathrm{H}$. H. the Begum in regard to her donation.

A letter was placed before the members from a Mr Michelle containing a request for information regarding the Mosque Fund Project. It was resolved that a copy of the circular letter be sent to him.

Confirmed: Ameer Ali ig November 1912

\section{A meeting of the Executive Committee of the London Mosque Fund was held on 19 November IgI3 at the India Office, Whitehall SW}

Present:

The Rt Hon Syed Ameer Ali (in the chair)

Mr C.A. Latif

Mr A.S.M. Anik

Mr Abdul Ghufar Khan

Mr Abbas Ali Baig

Mr T.W. Arnold (Secretary)

Mr Anik reported that $£ 300$ had been invested as decided at the last meeting and Mr Arnold reported the issue of letters to H.H. the Begum of Bhopal and other subscribers and to the Trustees setting forth the progress of the Fund.

The Secretary of the Trustees of the Mosque at Woking reported the transactions of a meeting of the Trustees on 20 October as follows:

(i) consideration of a letter dated io October I9I3 from the Treasury solicitor regarding the deed of transfer and the funds now in the possession of Mr Leitner; 
(ii) resolution that the Mosque should be insured as soon as funds are available;

(iii) sanction of the provisional arrangement made by Mr Abbas Ali Baig for the supervision and maintenance of the Mosque by Khwaja Kamaluddin*39 who was asked to insure the Mosque and the Memorial House, for the present, for fiooo;

(iv) resolution that Mr Anik be asked to act as Treasurer of the Trust Funds and Mr Arnold as Secretary of the Board of trustees.

Mr Anik laid before the meeting a statement of the accounts of the London Mosque Fund up to the 15 December I9I 3 and pointed out that the balance in hand in the banks including securities was $£ 5206$ -

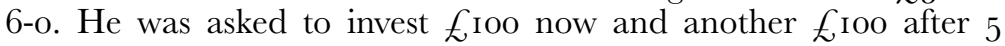
January I9I4.

Confirmed: Ameer Ali 22 January I9I4

\section{A meeting of the Executive Committee of the London Mosque Fund was held on 22 January 1914 at I4I Sloane Street, SW at 5 pm}

Present:

The Rt Hon Ameer Ali (in the Chair)

His Excellency Mundji Fikri Bey

Mr Mirza Abdul Ghaffar Khan

Mr Abbas Ali Baig

Mr G.A. Latif

Mr A.S.M. Anik

Prof T.W. Arnold

Mr Anik reported that he had invested $f_{\mathrm{I}} \mathrm{IO}$ as decided at the last meeting.

Letters from Khuwaja Kamaluddin and Mr Abdul Haq (Secretary of the Islamic Society ${ }^{40}$ ) were read, asking for a grant of money for the

\footnotetext{
${ }^{39}$ Khwaja Kamal-ud-Din wrote a large number of books on Islam (and religion more generally), which were published from Woking. Throughout his time in England he worked energetically to institutionalize Islam by mobilizing material and human resources. More specifically, he was committed to establishing a mosque in London, and in the meantime temporarily rented premises in which he regularly led congregational prayers.

${ }^{40}$ Anjuman-i-Islam (see The Times, 29 January I896 and I7 November I897) was a precursor of the Islamic Society; at the Eid celebration held at Caxton Hall under the auspices of the
} 
payment of the rent of a building in London for the purposes of a Mosque.

The Chairman explained that a grant could be made from the Mosque Fund without reference to the Trustees. Proposed by $\mathrm{Mr}$ Abbas Ali Baig and seconded by Moh Latif that this committee do recommend to the Trustees to sanction a grant of $\oint_{1}$, 20 a year out of the income of the Trust Fund in deposit with the Bank of England to the credit of the Trustees of the London Mosque Fund. The motion was carried.

Proposed by Mr Ameer Ali and seconded by His Excellency Mundji Fikri Bey that the administration of this grant be entrusted to a committee composed of $\mathrm{Mr}$ Abbas Ali Baig, Mr Anik and Khawaja Kamaluddin for renting a building or room or rooms for the performance of the Muslim prayers and for expenses incidental thereto; and that this committee submit an annual report as to how the money has been expended. The motion was carried.

$\mathrm{Mr}$ Arnold reported that a cheque for $£ 492$ was received from $\mathrm{Mr}$ Leitner's solicitors by the Woking Mosque Trustees who authorised Mr Anik their Treasurer to invest $£ 490$ in India Stock (gold) $3 \%$ per cent, and Mr Anik reported that the investment had been effected and that the Mosque and Memorial House had been insured for $\mathcal{E}_{\mathrm{I}, \mathrm{ooo}}$

Confirmed: Ameer Ali ig March IgI4

\section{A meeting of the Executive Committee of the London Mosque Fund was held on I9 March Igr4 at 3 pm at 4 I Sloane Street SW}

Present:

The Rt Hon Ameer Ali (in the chair)

Mr Abbas Ali Baig

Mr C.A Latif

Mr Willoughby Bullock (representing Sir William Bull)

Pan-Islamic Society (The Times, 22 December I903), an appeal was made for funds to be collected for the building of a mosque in London. There were further newspaper reports of gatherings organized by the Pan-Islamic Society from I907 onwards (see The Times, 28

January I907 and I3 June I907). 
Professor T.W. Arnold (Secretary)

The minutes of the previous meeting were read and confirmed.

In reference to the resolution passed by the Committee on 22 January I9I4 the secretaries reported that they received from the following trustees (Rt Hon Ameer Ali, Lord Ampthill, Moh Abbas Ali Baig, His Excellency Mundji Fikri Bey, Lord Rothschild and Sadigh es Salteneh) letters agreeing to the recommendation of the Committee that a grant of $\mathcal{E}_{\mathrm{I}} \mathrm{r} 2 \mathrm{a}$ a year out of the income of the Trust Fund be made to a Committee composed of Mr Abbas Ali Baig, Mr A.S.M. Anik and Khawaja Kamaluddin, who will administer the grant for the purpose of renting a building or room for the performance of Muslim prayers.

Lord Ampthill, Lord Rothschild and the Rt Hon Ameer Ali imposed a condition that the Trustees will have the power to withdraw or vary their consent to the grant, whenever it may appear to them desirable to do so. But no answer had yet been received from His Highness Mr Aga Khan.

Mr Bullock stated that he did not consider it expedient to take final action until an answer had been received from him also, as he was one of the Trustees.

Mr Baig therefore proposed that an urgent letter be sent to His Highness informing him that all the other Trustees had given their consent and requesting an early reply.

Resolved (subject to the assent of His Highness the remaining trustee) that the grant should take effect from I January I9I4 and be paid quarterly to the committee composed of Mr Abbas Ali Baig, Mr A.S.M. Anik and Khawaja Kamaluddin.

Mr Ameer Ali pointed out that the time had come for continuing the appeal for funds for the London Mosque and it was resolved that in reference to the expenditure necessary for such an appeal the balance of quarterly income of the Trust Funds in the Bank of England after payment to the above mentioned committee composed of Mr Abbas Ali Baig, Mr A.S.M. Anik and Khawaja Kamaluddin be utilized for this purpose.

The following form was approved for the cards announcing the Friday prayer: 


$$
\text { Allah }-O-\text { Akbar }^{41}
$$

The Jooma Namaz $z^{42}$ will be held at the Lindsay Hall, Notting Hill Gate, $W$., regularly every Friday at I2 Noon until further notice.

Mr Khawaja Kamal-ud-Din of the Mosque, Woking will deliver the sermon and the Dua ${ }^{\mathrm{H}}$ will be recited by Haireddin Effindi and Lord Headley* respectively in Arabic and English.

All Moslems are cordially invited.

The secretary submitted the following statement of the accounts of the London Mosque Fund to 3i December igi3:

Statement of Accounts of the London Mosque Fund

Memo of Receipt:

Donations received

Library Lecture Room

Dividends on Investments

\section{Total:}

Expenditure

$\underline{\text { Balance at Banks: }}$

Bank of England

London South Western Bank

(with Mr Anik)

Securities with Bank of England

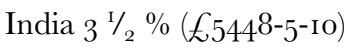

\section{Total:}

$£ 3^{16-6-8}$ Dividends

$\mathcal{E}$ 98-7-I Expenditure

£217-19-7 still remaining as balance out of Dividends to 31.12.13

The account of the donations is intact.

Confirmed: Ameer Ali 6 June ı9ı6

\footnotetext{
${ }^{41}$ 'Allah-o-Akbar' (also written 'Allahu Akbar') is the Arabic for 'God is the Greatest' or 'God is Great', and is the first line of the Muslim call to prayer (Adhan or Azan).

${ }^{42}$ Fooma Namaz (often transliterated as Fuma Namaz) is the Persian/Urdu term for Friday congregational prayers.

${ }^{43}$ Premises rented at this time for Friday congregational prayers.

44'Supplication to God', or prayer.
} 


\section{A meeting of the Executive Committee of the London Mosque Fund was held on Tuesday 6 June 1916 at 5.30 pm at 4I Sloane Street, SW}

Present:

The Rt Hon Ameer Ali (in the chair)

Sir William Bull MP

W Abbas Ali Baig

Mirza Abdul Ghaffar Khan

Mr A.S.M. Anik

T.W. Arnold (Secretary)

The minutes of the previous meeting were read and confirmed. With reference to the consent of $\mathrm{H} \mathrm{H}$ the Agha Khan, the Chairman reported that when $\mathrm{H} \mathrm{H}$ visited England, he verbally expressed his agreement with the other Trustees.

The Chairman explained the arrangements for the administration of the grant of $f_{1} 20$ for a Namaz-gah ${ }^{45}$ and stated that Maulavi Sadrud Din $^{* 4^{6}}$ had taken a room for this purpose in 39 Upper Bedford Place, without however having previously obtained the permission of the sub-committee. The following rules were framed for the management of the Namaz-gah, but Maulavi Sadrud Din had expressed his inability to carry them out:

Rules for the Management of the Namaz-gah in London

I. Any place rented by the London Mosque Fund Committee to serve as a Namaz-gah in London shall be devoted exclusively to Divine Worship and Religious Services.

2. The Namaz-gah shall always remain available for Namaz to every Muslim of any Islamic sect.

3. No society, association or other body shall be permitted to use it for a secular purpose or for holding therein any meeting unconnected with Divine Worship.

4. No person shall be allowed to reside therein or to make any private or secular use thereof.

${ }^{45}$ Persian/Urdu term for a place for prayer or worship.

${ }^{46}$ Maulavi Sadr-ud-Din took the place of Khwaja Kamal-ud-Din as imam of the Woking Mosque when the latter was away from England between I9I4 and I9I6. 
5. The London Mosque Fund Committee or the sub-committee thereof appointed for the control and supervision of the Namazgah may, if they think fit, relax the provisions of the Rules 3 and 4 for special reasons consistently [sic] with the main object of the Namaz-gah. They may also permit the temporary renting of any extra room or space not used or required for Divine Worship. The rent realised in such cases shall be credited to the Namaz-gah fund.

6. The Pesh $\operatorname{Imam}^{47}$ for the time being shall be responsible for the proper upkeep of the Namaz-gah and the furniture therein, and also for the due observance of the rules, any breach of which should be forthwith reported to the Secretary to the subcommittee.

Sir William Bull discussed the situation and pointed out that the arrangement with Maulavi Sadrud Din might be terminated at any time, if due notice were given.

A letter dated I June from Maulavi Sadrud Din was read. The Chairman stated his opinion that the tone of this letter was reasonable, and it was resolved that the following answer be sent to Maulavi Sadrud Din:

"The Committee of the London Mosque Fund considered your letter of I June. They have noted your assurance that the rules are being carried out by you. They do not wish to impose upon you any obligations that are not fair or reasonable, but as you hold the keys, you are bound to be responsible for the rooms and their contents and the maintenance of order. They trust that matters will proceed smoothly in the future and have adjured further consideration of the matter for a period of six month".

It was resolved that in view of the death of Lord Rothschild, the existing trustees should be approached and the name of Lord Lamington* should be suggested to fill up the vacancy.

The Treasurer submitted the account on fol. I9 which the Ghairman signed.

It was resolved that a cheque for $\AA^{25}$ be handed to the Treasurer to be paid into the L and SW Bank and that $\mathcal{E}_{\mathrm{foo}}$ be invested in

${ }^{47} \mathrm{Urdu} /$ Persian term for the chief leader of prayers at a mosque. 
Exchequer Bonds (free of tax) and that after i July a further sum of £5o be invested in Exchequer Bonds.

Confirmed: Ameer Ali 23 November 1917

\section{A meeting of the Executive Committee of the London Mosque Fund was held on 23 November I9I 7 at $3.30 \mathrm{pm}$ at 4I Sloane Street SW}

Present:

The Rt Hon Ameer Ali (in the Chair)

Sahibzada Aftab Ahmed Khan*

Mirza Abdul Ghaffar Khan

Mr A.S.M. Anik

The minutes of the previous meeting were read and confirmed.

The Treasurer submitted the accounts up to 23 November I9I7 which were passed and signed by the Chairman.

It was resolved that meetings of the Executive Committee shall in future be held once a quarter.

Mr Mirza Hashim Isfahani ${ }^{* 4^{8}}$ was duly elected a member of the Executive Committee.

Resolved that M H Isfahani be appointed to visit periodically on behalf of the Executive Committee the Namaz-gah and report to the Committee as to the conduct of the Namaz-gah.

The Executive Committee confirmed the arrangements made by the Namaz-gah sub-committee in reference to the transfer from Upper Bedford Place to in Campden Hill Road ${ }^{49}$ and the expenditure connected therewith.

Resolved that Khaja Kamaluddin be requested to furnish a report as to the condition and success of the Namaz-gah from the date of his taking over charge from Maulvi Sadarruddin.

\footnotetext{
${ }^{4}{ }^{8}$ Sometimes spelt 'Ispahani'.

${ }^{49}$ In the absence of a mosque, Lindsay Hall in Notting Hill Gate, supported by the LMF, had been the first building rented for congregational prayers. Referred to as the 'London Muslim Prayer House', it was also used by the Muslim Literary Society and the London Muslim Association for their varied intellectual and cultural activities. Prayers had then been conducted in 39 Upper Bedford Place, before transferring to Campden Hill Road, Notting Hill Gate. See Islamic Review, September I9I7 and May I920.
} 
Resolved that $£ 9$ a year be granted to the clerk of the British Red Crescent Society ${ }^{5^{\circ}}$ and the London All India Moslem League ${ }^{51}$ for all clerical work connected with the London Mosque Fund commencing from I November I9I4.

Resolved that the official habitation of the London Mosque Fund shall be at 4I Sloane Street S.W.I.

Resolved that a fresh letter of appeal inviting influential persons to become members of the General Committee, and asking those who are already members of this Committee to contribute to the funds of the Mosque be drafted.

A communication from the Hon Treasurer of the Islamic Society was read and it was resolved that he should be informed that the accounts will be published in due course.

Resolved that $\mathrm{Mr}$ Anik be requested to send a statement of the accounts to the Press for publication.

Confirmed: Ameer Ali i5 March igi8

\section{A meeting of the Executive Committee of the London Mosque Fund was held on I5 March I9I8 at 5 pm at 4 I Sloane Street SWI}

\section{Present:}

Rt Hon Ameer Ali (in the chair)

Sahibzada Aftab Ahmed Khan

Mirza Abdul Ghaffar Khan

\footnotetext{
${ }^{50}$ Ameer Ali was the founder and President of the British Red Crescent Society. During the Turco-Italian War it provided for the relief of the Ottoman sick and wounded and for widows and orphans in Tripoli (now capital of Libya). It also offered medical help. See The Times, 8 November I9I I; 23 January I9I2; 8 April I912; 5 November I912. In I922 it remitted £7,80o to the Ottoman Red Crescent Society for relief in Constantinople. See The Times, I3 January I922; 3 March 1926.

${ }^{51}$ The 'London All-India Moslem League' was founded by Syed Ameer Ali; on 6 May I908 he delivered its inaugural address at Westminster Palace Hotel (see The Times, 7 May I908). Its objects included 'the advancement and safeguard by all constitutional and loyal methods of the special interests of the Mahomedan subjects of the King [...] The London League has been a most valuable exponent of Moslem sentiments and opinion [ . . .] by sober, well-reasoned and detailed representations it has made to the India Office, the Colonial Office and other Whitehall departments it has taken the acknowledged lead in formulating and giving expression to Indian Moslem opinion' (see The Times, 3I October I9I3).
} 
Professor T. W. Arnold

Mr A.S.M. Anik

The minutes of the previous meeting were read and confirmed.

The resolution of the Committee as to the publication of the accounts of the London Mosque Fund was carried into effect by the Hon Treasurer and they were printed in the Westminster Gazette of 20 December I9I7 among other papers.

The Hon Treasurer submitted the accounts up to ${ }_{5}$ March IgI8 and they were signed by the Chairman.

A report by Khwaja Kamaluddin on the conduct of the Namazgah was read and it was resolved that this report, together with the accounts of the London Mosque Fund (published in the Westminster Gazette of 20 December $1917^{52}$ ) be sent to the Editor of The Islamic Review. $^{53}$

Confirmed: Ameer Ali 5 November 1919

\section{A meeting of the Executive Committee of the London Mosque fund was held on 5 November 1919 at $4.30 \mathrm{pm}$ at I8 Sloane Street, SWr}

Present:

Rt Hon Ameer Ali (in the chair)

Mr A.S.M. Anik

M.H. Isfahani

The minutes of the previous meeting were read and confirmed.

Sir William Bull was prevented by public work from attending. In his letter to the Chairman he wrote as follows:

\footnotetext{
${ }^{5^{2}}$ The accounts were published as part of a letter from Ameer Ali to the editor, which contained details of some of the most prominent donors to the LMF and an implicit appeal for contributions. On 23 November I9I7, the balance was $£_{613}{ }^{1-8-6}$. See Westminster Gazette, 20 December I9I7.

${ }^{53}$ The original name of the Islamic Review when its publication started in February I9I3 was Muslim India and the Islamic Review but by I9I4 it had changed to The Islamic Review and Muslim India. In I92I it was shortened to The Islamic Review. For more details about the founding of the journal, see http://www.wokingmuslim.org/history/is-rev/founding.htm (accessed Io January 2010).
} 
"I have your letter of the ist instant but regret that I shall be unable to get to the meeting tomorrow. I, however, agree with your view that the London Mosque Fund, the British Red Crescent Society and the London Moslem League should each contribute $£ 40$ towards the annual rent of $\mathcal{E}_{\mathrm{I} 2 \mathrm{O}}$ for the premises at I8 Sloane Street". ${ }^{54}$

Proposed by Mr Isfahani seconded by Mr Anik that the London Mosque Fund, the British Red Crescent Society and the London Moslem League should each contribute $£ 40$ towards the annual rent of $\mathcal{E}_{\mathrm{1} 20}$ for the premises at I8 Sloane Street.

It was resolved that the Honorary Treasurer be requested to have the lease [illegible] in his name as representing the three societies.

Confirmed: Ameer Ali I8 June I920

\section{A meeting of the Executive Committee of the London Mosque Fund was held on 18 June 1920 at 6 pm at I8 Sloane St, SWI}

Present:

The Rt Hon Ameer Ali

Sir Abbas Ali Baig

Mr A.S.M. Anik

Mr M. H. Isfahani

Prof T.W. Arnold (secretary)

The minutes of the previous meeting were read and confirmed.

The accounts of the London Mosque Fund from 9 November igio to I8 June I920 were submitted by Mr A.S.M. Anik and approved. Mr

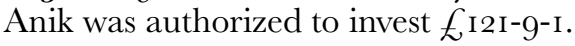

A vote of thanks to Mr Anik was proposed and carried unanimously for his self sacrificing work in keeping the accounts for the last ten years.

Confirmed: Ameer Ali i6 March I92 I

\footnotetext{
${ }^{54}$ Premises rented for the purpose of holding congregational prayers, especially on Fridays.
} 


\section{A meeting of the Executive Committee of the London Mosque Fund was held on 16 March 1921 at 4.45 at I8 Sloane Street}

\section{Present:}

The Rt Hon Ameer Ali (chairman)

Sahibzada Aftab Ahmed Khan

Mr A.S.M. Anik

Mr M. H. Isfahani

Mr A Yusuf Ali* (after his election)

Prof T.W. Arnold (secretary)

The minutes of the previous meeting were read and confirmed.

The Rt Hon Ameer Ali proposed and Sahibzada Aftab Ahmed Khan seconded the election of Mr Yusuf Ali as a member of the Executive Committee. The proposal was carried unanimously and Mr Yusuf Ali took his seat as a member of the Committee.

The Chairman drew attention to complaints in regard to the Woking Mosque ${ }^{55}$ and as the Committee of the London Mosque Fund is responsible for the management of this mosque, he proposed that a sub-committee (consisting of $\mathrm{Mr}$ Anik, Mr Isfahani [convenor] and $\mathrm{Mr}$ Yusuf Ali) be appointed to enquire into the occupation, conduct and maintenance of the Woking Mosque together with the Namaz-gah at Campden Hill Road. His Proposal was carried unanimously and the gentlemen nominated consented to act on the sub-committee.

The accounts of the London Mosque Fund from 9 November igio to 28 February I92I were submitted by $\mathrm{Mr}$ A.S.M. Anik and were approved. It was decided that in future accounts should be made up yearly by the calendar year.

Confirmed: Ameer Ali i4 October I92 I

\footnotetext{
${ }^{55}$ It is not clear what these complaints were as they are not discussed in detail in the
} Minutes here. 


\section{A meeting of the Executive Committee of the London Mosque Fund was held on I4 October I92I at 4I Sloane Street SW}

Present:

The Rt Hon Ameer Ali (chairman)

Mr A.S.M. Anik

Sir T.W. Arnold (secretary)

The minutes of the last meeting were read and confirmed.

The Chairman reported that Mr Yusuf Ali had resigned from the Committee on the eve of his departure to India to take up his appointment in the service of His exalted Highness the Nizam of Hyderabad..$^{6}$

The Chairman also reported that no report had been received from the sub-committee appointed to enquire into the maintenance of the Woking Mosque and there was no evidence that any action had been taken.

Read a letter from Mrs Gardner, ${ }^{57}$ at Campden Hill Road, dated 9 August complaining of her dismissal by Maulvi Mustafa Khan, Imam of the Woking Mosque and also a letter from Maulvi Mustafa Khan in answer to the Chairman's request for an explanation.

Resolved that the Maulvi be asked to inform the Committee whether Mrs Gardner has vacated the house, and who is at present the caretaker in II I Campden Hill Road, and on what date Khwaja Kamal ud-Din is expected to arrive and resume charge of the Namaz-Gah.

Resolved that all other matters in connection with the Namaz-Gah be reserved until the arrival of Khwaja Kamal ud-Din.

Confirmed: Ameer Ali 8 December I92 I

\footnotetext{
${ }^{56}$ Soon after the signature of the Treaty of Versailles in I9I9, Abdullah Yusuf Ali entered the service of the Nizam (ruler) of the state of Hyderabad, India, and in I92I was appointed as Revenue Member of the Council of the State. See The Times, I5 December 1953.

${ }^{57}$ Caretaker at II I Campden Hill Road.
} 


\section{A meeting of the Executive Committee of the London} Mosque Fund was held on 2 December I92I at 5.15 pm at I8 Sloane Street SW

\section{Present:}

The Rt Hon Ameer Ali (chairman)

Mr A.S.M. Anik

Mr Isfahani

Sir T.W. Arnold (secretary)

The Chairman reported that Khwaja Kamal-ud-Din had called upon him that he had found everything in good order back at Woking and in I I Campden Hill Road, and that Mrs Gardner had left and that no further difficulty has arisen in regard to her.

The proposal was considered to devote a sum of ioo guineas out of the surplus income of the London Mosque Fund for the improvement of the Muslim Burial Ground Brookwood Cemetery. ${ }^{58}$ An estimate of the proposed improvement submitted by the Managing Director of the London Necropolis Company was considered and accepted unanimously. It was further resolved that a copy of this resolution be sent to the Trustees of the London Mosque Fund.

The Hon Treasurer submitted a statement of accounts as per attached paper, of the present state of the London Mosque Fund.

Confirmed: Ameer Ali (Chairman)

\footnotetext{
${ }^{58}$ Known as the London Necropolis, the Brookwood Cemetery was opened in November 1854, with the aim of solving London's burial problem. In time, it became Britain's largest cemetery, catering generously for pauper burials, and more than 240,000 people of all denominations have been buried there. For Muslims, it was a particularly special place since it contained the oldest Muslim burial ground in the country, dating back to the late nineteenth century when a plot reserved for use by the nearby Oriental Institute located in Woking was set aside at the request of G.W. Leitner. During the First World War, Muslim soldiers from the Western Front who died in hospitals in Britain were buried at a dedicated Muslim cemetery on Horsell Common. In the inter-war period, Brookwood was the only public cemetery serving London with a section designated for Muslims, and since there was a mosque nearby at Woking a proper Muslim burial could be ensured. Hence it was chosen as the final resting place by many leading Muslims in Britain at this time. See H. Ansari, "'Burying the dead": making Muslim space in Britain', Historical Research, 8o, no. 210 July 2007), pp. 545-566.
} 
A meeting of the Committee of the London Mosque Fund was held on Monday 23 July 1923 at 4.30 pm at I8 Sloane ${\text { Street } \mathbf{S W}^{59}}^{50}$

Present:

The Rt Hon Ameer Ali (chairman)

Mr A.S.M. Anik

Mr S Aftab Ahmed Khan

Mr G. A. Ardalani ${ }^{60}$

Sir T.W. Arnold (secretary) ${ }^{6 t}$

Rt Hon Syed Ameer Ali proposed and Mr Aftab Ahmed Khan seconded that Sir Mohamad Rafique* be elected a member of the Executive Committee of the London Mosque Fund. Mr Anik proposed and Mr Ameer Ali seconded that Mirza Kajim Husain be elected a member of the Executive Committee of the London Mosque Fund. Both these motions were carried unanimously.

The Hon Treasurer submitted the accounts from 9 November I9Io to 2 I July I923 giving full details of receipts and expenditure as per statement of accounts hereto attached. Duly considered and were passed.

Confirmed: Ameer Ali Chairman 24June I924

\section{A meeting of the Executive Committee of the London Mosque Fund was held on Tuesday 24 June 1924 at I8 Sloane Street at 4.15 pm}

Present:

The Rt Hon Ameer Ali (chairman)

Mr A.S.M. Anik

Sir T.W. Arnold (secretary)

\footnotetext{
${ }^{59} \mathrm{By}$ now these premises contained the offices of the British Red Crescent Society and the London All-India Muslim League.

${ }^{60}$ Gholam Ali Khan Ardalani, Chargé d'Affaires at the Persian Legation in London.

${ }^{61}$ Crossed out in the Minutes.
} 
The Chairman brought to the attention of the members present that Sir Ali Imam Moid-ul-Mulk* had been elected by the agreement of the members obtained by correspondence - this course of action having been adopted in order to obviate delay. The meeting unanimously confirmed the election.

The audited accounts from 9 November igio to 3i December I923 of the London Mosque Fund, audited by Messrs. Hayes chartered accountants, and certified dated 24 January 1924 were placed before the Committee and passed.

Resolved that in the opinion of the Committee the time has arrived for renewing the appeal after the amendment, for the erection of a mosque in London. Further that representatives from the Egyptians and Afghan legations be invited to join the Executive Committee. Resolved further that $\mathrm{H} \mathrm{H}$ King Fuad ${ }^{62}$ of Egypt and $\mathrm{H} \mathrm{H}$ the King of Afghanistan $^{6_{3}}$ and that the Nizam of Hyderabad ${ }^{6_{4}}$ be invited, through the proper channels, to be patrons of the Fund in conjunction with $\mathrm{H} \mathrm{H}$ the Shah of Persia.

Resolved that the expediency of approaching His Majesty's Government for the Grant of a site for the proposed Mosque should be considered, and that decision in this matter be left in the hands of the Chairman.

The Treasurer moved that as one of the Trustees for the London Mosque Fund is leaving for India in August next, and as his absence is likely to be permanent, investments standing in his name, jointly with the Chairman, should be altered to the name of the Chairman in conjunction with some other Trustee.

Resolved that the Chief Cashier of the Bank of England be requested to alter such investments into the name of the Chairman in conjunction with Lord Lamington.

Confirmed: Ameer Ali 20 May I925

\footnotetext{
${ }^{62}$ King Fuad (1868-1936) was king of Egypt from I9I7 until his death in 1936.

${ }^{63}$ Amanullah Khan (I892-I960) was Amir (ruler) of Afghanistan from I9I9 to I929.

${ }^{6}$ Nizam, a shortened version of Nizam-ul-Mulk, meaning 'Administrator of the Realm', was the title of the native sovereigns of Hyderabad State, India, which had belonged to the Asaf Jah dynasty since I7I9.
} 


\section{A meeting of the Executive Committee of the London Mosque Fund was held on Wednesday 20 May 1925 at I8 Sloane Street at $4 \cdot 30 \mathrm{pm}$}

Present:

The Rt Hon Ameer Ali (chairman)

Sir Mohammed Rafique

Mr G.A. Ardalani

Sir T.W. Arnold (secretary)

In November 1924 His Highness the Aga Khan urged that a memorial be sent to His Exalted Highness the Nizam on behalf of the London Mosque Fund; and accordingly such a memorial was sent on 26 November I924 signed by himself and the Right Honourable Ameer Ali. An answer was received dated 30 April 1925 granting a further donation of $£$ I, ooo from $\mathrm{H} E \mathrm{H}$ the Nizam.

The letter was read from $\mathrm{H} \mathrm{H}$ the Aga Khan urging that $\mathrm{H} \mathrm{E} \mathrm{H}$ the Nizam should be approached again and that it be pointed out to him that the amount of the donation was not in harmony with his exalted position and might damage the success of the project of erecting a mosque in London.

Mr Ameer Ali undertook to carry out this proposal in conjunction with His Highness the Aga Khan.

Confirmed: Ameer Ali Chairman 3I October 1925

\section{A meeting of the Executive Committee of the London Mosque Fund was held on Saturday 3I October 1925 at I Sloane Street at 3 pm}

Present:

The Rt Hon Ameer Ali (chairman)

Sir Mohammed Rafique

Mr G.A. Ardalani

Mr A.S.M. Anik (treasurer)

Prof A.W. Azzam

Sir T.W. Arnold (secretary) 
In connection with the minutes of the last meeting $\mathrm{Mr}$ Ameer Ali reported that he had in conjunction with $\mathrm{H} \mathrm{H}$ the Aga Khan sent a letter to His Exalted Highness the Nizam but that no answer had yet been received by him.

The Chairman read a letter from Mr Anik the Treasurer urging the stabilisation of the London Mosque Fund. In view of the absence of several of the Trustees from this country, it was resolved that Counsel's opinion should be taken as to what steps should be taken for drawing up a deed by which a regular trust may be created in the name of the London Mosque Fund.

The Treasurer reported that there is a balance of $f_{\mathrm{I}, 209}$ in the current account at the Bank of England.

Resolved that about $\mathcal{E}_{\mathrm{I}}$,ooo be invested in some Trust securities.

Resolved that a letter be sent to Khwaja Kamaluddin drawing his attention to the fact that under the Trust Deed the Woking Mosque is placed under the general supervision of the Committee of the London Mosque Fund, and the Committee of the London Mosque Fund would be glad to have particulars as to the proposed enlargement of the Woking Mosque so as to accommodate 2,000 persons as mentioned in the "Sunday Times" of 23 October. ${ }^{65}$

Confirmed: Ameer Ali chairman

\section{A meeting of the Executive Committee of the London Mosque Fund was held at 4 o'clock on Saturday 5 December 1925 at 2 Cadogan Place SWI}

Present:

The Rt Hon Ameer Ali (chairman)

Sir Mohammed Rafique

Sir T.W. Arnold (secretary)

Mr A.S.M. Anik (treasurer)

\footnotetext{
${ }^{6}$ The date recorded for this issue of the Sunday Times is incorrect, as 23 October 1925 was a Friday.
} 
Mr Anik reported that $\mathcal{E}_{\mathrm{I}}$,ooo (face value) were invested in $5 \%$ War Loan I929-47, in the names of the Right Honourable Lord Lamington and the Right Honourable Ameer Ali, registered in Bank of England transferable by deed.

The Secretary reported that he had received from Khwaja Kamaluddin a letter dated I4 November I925 stating that the contemplated extension to the Woking Mosque is intended to accommodate 200 persons ${ }^{66}$ by adding two wings to the North and South sides of the mosque, and two houses for ablution for ladies and gentlemen and that the work will be carried out under the supervision of $\mathrm{Mr}$ Charles Nicholson, who is making a design and estimates.

In reply the Secretary wrote asking for further particulars.

Resolved that the Cashier of the Bank of England be thanked for his communication of 24 November to the Chairman of the Executive Committee relating to the change of the designation of the Fund from the names of Lord Ampthill and others to the name of the "London Mosque Fund" and to the authorisation for drawing cheques on the Fund.

In consequence of the departure from England of Mundji Fikri Bey and Sadik Sultaneh it has become necessary for the due administration of the Trust to fill the place of one or both of them.

It was resolved that Sir Mohammad Rafique, member of the Council of the Secretary of State for India and a member of the Executive Committee be appointed a Trustee in the place of Mundji Fikri Bey.

Resolved further that a copy of this Resolution be forwarded to the Chief Cashier of the Bank of England.

Resolved that Sir Thomas W. Arnold be appointed the pro tem secretary of the Trustees of the London Mosque Fund in the place of Mr C.A. Latif, resigned.

Confirmed: Ameer Ali i2 May i926

\footnotetext{
${ }^{66}$ The letter from Khwaja Kamal-ud-Din corrects the figure of 2,00o recorded in the minutes of 3 I October 1925 as reported in what seems to be the 25 October 1925 issue of the Sunday Times.
} 


\section{A meeting of the Trustees and of the Executive Committee of the London Mosque Fund was held at 4 o'clock on Wednesday 12 May 1926 at 2 Cadogan Place SWI}

\section{Present:}

The Rt Hon Ameer Ali (chairman)

The Rt Hon Lord Lamington

Mr G. A Ardalani

Mr A.W. Azzam

Dr Saud S. Mohamedi ${ }^{67}$ (as supervisor of I I I Campden Hill Road) Sir T.W. Arnold (secretary)

The minutes of the last meeting were read and confirmed.

The Chairman raised the question whether the sum of $\mathcal{E}_{\mathrm{I}} \mathrm{3}$ o should continue to be paid for the Namaz-Gah at i I , Campden Hill Road. Resolved that a letter be sent to Kamal ud-Din enquiring whether he was prepared to take over this house and make himself responsible for the payment of the rent, and whether in this case he would let one large room to the London Mosque Fund and at what rent.

The purchase of a house for the purpose of a Mosque was considered by the meeting to be an infraction of the Trust, the purpose of which is the building of a mosque.

Resolved that it was not in accordance with the purpose of the Trust to devote any portion of the income of the Trust towards defraying the expenses of the burial of indigent Moslems dying in the neighbourhood of London.

Read a letter from Sir Abbas Ali Baig resigning his position as a Trustee of the London Mosque Fund and as a member of the Committee. His resignation was accepted accordingly.

Read letters from His Highness the Aga Khan and the Rt Hon Lord Ampthill, regretting their inability to attend the meeting.

Resolved that Mr Withers (of Withers, Bensons, Currie, Williams and Co.) 4, Arundel Street, W.C, be appointed to draw up a Trust Deed for the London Mosque Fund.

Draft notes for the preparation of the Trust Deed were read and accepted by the Committee.

\footnotetext{
${ }^{67}$ Member of the Moslem Society of Great Britain.
} 
Resolved that Jaafar Pasha Askari, representative of the Iraq Government and Shuja ud-Daulah Khan, the Afghan Minister be invited to join the Committee.

The Treasurer submitted a statement of account which was accepted by the Committee.

Confirmed: Ameer Ali 6 November 1926

\section{A Joint Meeting of the Trustees of the Executive Committee of the London Mosque Fund, held at I8 Sloane Street, S.W, on Saturday, 6 November 1926 at 4 pm}

\section{Present:}

The Rt Hon Ameer Ali (Chairman)

The Rt Hon Lord Ampthill

Sir Mohammed Rafique

Sheikh Abdul Wahab-al-Azzam

Mr A.S.M. Anik (Hon Teasurer)

Mr G.A. Ardalani

I. The minutes of the previous meeting were read and duly confirmed.

2. The Chairman read a letter he had received from the Honorary treasurer dated 5 November regarding the mention in the Trust Deed ${ }^{68}$ of the sums of $f 6,000$ as on deposit at the Bank of England in the name of the London Mosque Fund. The Honorary Treasurer pointed out in his communication that the actual market value of the securities was only $£, 5,5^{\text {I I }}$, the sum of $£ 6$,ooo represented the "purchase value". The Chairman reported that on receipt of this letter he immediately sent an extract from it by special messenger to Mr Withers for his consideration before the meeting; and had just received Mr Withers'

\footnotetext{
${ }^{68}$ While monies were being collected and partly invested from I9Io onwards, it was not until I9 November 1926 that the LMF was officially registered as a trust for the purpose of building a mosque in London. The following were declared its trustees: Sir Sultan Mahomed Shah Aga Khan; C.A.N. Cochrane-Baillie, 2nd Baron Lamington, A.O.V. Russell, 2nd Baron Ampthill; Syed Ameer Ali; and Sir Mohamed Rafique. No copy of the Trust document was included with the Minutes but the 'Declaration of Trust' is available in the library at the ELM Archives.
} 
reply ${ }^{69}$ asking that the execution of the Trust Deed by the Trustees might be postponed so that an "accurate rental and description of the securities representing the funds collected, at the date of the Deed" might be included in a fresh engrossment which he would prepare after these particulars had been furnished by the Honorary Secretary.

3. After discussion the Committee was of opinion that no difference as to the "market value" and the "face" or "purchase" value of the securities should be introduced into the Trust Deed but a simple statement as to the details of the Fund which was forthwith furnished by the Honorary Treasurer, as follows:

Credit Account with the Bank of England in the name of the London Mosque Fund

$$
£ 284^{-15-3}
$$

Securities registered with the Bank of England in the names of the Rt Hon Lord Lamington and the Rt Hon Syed Ameer Ali, purchased for $£ 6,857-\mathrm{II}-4$

$\begin{array}{ll}\text { India } 3 \% \text { Stock } & £, 5,8 \mathrm{I} 4^{-\mathrm{I}-8} \\ \text { Loan } 5 \% \mathrm{I} 927 / 47 & £ \mathrm{I}, 5^{\mathrm{OO}}\end{array}$

4. It was agreed to leave $\mathrm{Mr}$ Withers to insert these particulars in the Fund Trust Deed in their proper phraseology and on Lord Ampthill's suggestion it was also agreed to request Mr Withers when he had prepared the fresh engrossment for execution, to send it round himself either by hand or through the post, to the various Trustees for execution as he (Mr Withers) would have the proper facilities for doing this expeditiously.

6. [sic] Rules for the Executive Committee The Chairman reported that he had received a letter from Lord Ampthill criticising the draft Rules which had been already circulated to the Trustees and the Executive Committee. This letter he had sent to Mr Withers for consideration together with a memorandum containing certain observations and suggestions as regards the amendment of the Rules, particularly nos. 7, IO, I9, and 23. Mr Withers had accordingly amended the Rules which were forthwith read and after discussion Rules 7, Io and 23 as amended were approved, and Rule i9 was further amended by the meeting to read thus: "The Executive Committee shall have power to delegate the collecting of funds in furtherance of the objects of the Fund to any local committee or committees

\footnotetext{
${ }^{69} \mathrm{Mr}$ Withers of the Trust's solicitors, Messrs. Withers, Bensons, Currie, Williams \& Co., 4 Arundel Street, Strand, WC.
} 
subject to any regulations that the Executive Committee may impose". ${ }^{\circ 0}$

6. It was unanimously agreed to delete Rule 22.

7. Burial of Indigent Moslems. The Chairman reported that another point had been raised by the Honorary Treasurer in his letter of the 3 November in regard to the burial of Indigent Moslems dying in London - to the grant of $£_{105}$ made by the London Mosque Fund to the Necropolis Co., for the perpetual upkeep of a piece of ground in the Brookwood Cemetery for the burial of Mohammedans and for which an agreement was held between the Trustees of the London Mosque Fund and the London Necropolis Co. The grant was for keeping the burial ground in proper repair but as far as the actual burial of the Indigent Moslems was concerned, it was resolved at the meeting of the Trustees and the Executive Committee on the I2 May last that it was not in accordance with the purpose of the Trust to devote any portion of the income of the Trust towards the expenses of the burial of Indigent Moslems dying in the neighbourhood of London. The matter was fully discussed and it was resolved that the London Mosque Fund is not in a position to undertake any expense in connection with the burial of Indigent Moslems as it does not come within the Trust for the erection of a mosque. ${ }^{71}$

8. Subject no. 4 on the Agenda, viz. "the consideration of the share of the rent of ig Sloane Street to be paid by the London Mosque Fund" was postponed.

Confirmed: Ameer Ali Chairman 31 December 1926

\footnotetext{
${ }^{70}$ The rules referred to are not attached to the Minutes. However, the Memorandum of Association (the document that regulates a company's activities) of the East London Mosque Trust Limited, dated 25 April I949, is attached as Appendix II.

${ }^{71}$ Shortly afterwards, a fund was started for the provision of the burial of indigent Muslims in accordance with Islamic rites. The Aga Khan, the president of the Indigent Moslem Burial Fund, donated $£ 200$ and the chairman, Ameer Ali, 50 guineas (Lord Lamington became chairman in I93I). A.S.M. Anik, the honorary secretary and treasurer, contributed EIoo. A plot of ground was reserved for burial and Barclays Bank acted as trustees (see The Times, I4 April I925). While the Nizam of Hyderabad contributed $f_{1}$, ooo, it was thought that a minimum of $£ 5,000$ was necessary to generate sufficient income to provide indigent Muslims with a decent burial and to keep the ground in good order (see The Times, 3 April I928). See below, p. I29, for a copy of the Deed of Declaration of 'The Indigent Moslems Burial Fund' Trust, dated ig December 1927 and with Ameer Ali and A.S.M. Anik named as Trustees.
} 


\section{A meeting of the Trustees and the Executive Committee of the London Mosque Fund held at 2 Cadogan Place, S.W. on Friday 3I December 1926 at $4 \cdot 30 \mathrm{pm}$}

\section{Present:}

The Rt Hon Ameer Ali (in the chair)

The Rt Hon Lord Lamington G.C.I.E, G.C.M.G

The Rt Hon Lord Ampthill G.C.I.E, G.C.B

Sir Thomas Arnold, C.I.E, LL.D

Abdul Rahman Bey Fikry ${ }^{72}$

Dr Saud S. Mohamedi (as supervisor of the Namaz-gah at III Campden Hill Road)

I. The minutes of the last meeting were read and confirmed.

2. Mr Abdul Rahman Bey Fikry was formally introduced as a member of the Executive Committee.

3. A proposal made by the Honorary Treasurer to hire a safe at the Safe Deposit was discussed. Proposed by Lord Ampthill and seconded by Lord Lamington and carried without dissent that the Trust Fund be deposited with Messrs. Withers, the solicitors.

4. The location of the Namaz-gah in I I Campden Hill Road was discussed. A letter from Mr J. W. Lovegrove* was read in which he stated that the best centre would be near Oxford Circus. The Chairman explained the circumstances under which the London Mosque Fund agreed to pay the rent for the Namaz-gah and supplied the furniture. After some discussion it was proposed by Lord Ampthill and seconded by Lord Lamington that the payment to Messrs. G.H. Watts Ltd. of $£ 300$ since 1920 and for the present year in respect of rent for the premises at in Campden Hill Road, should be and is hereby sanctioned. The motion was put to the vote and was carried without dissent.

5. Lord Ampthill then proposed and Lord Lamington seconded that the supervisor of the Namaz-gah be requested to look out for a more suitable and convenient place for a Namaz-gah at a rental not exceeding $£ \mathrm{I} 5 \mathrm{O}$ per annum, and to submit a report in respect of

\footnotetext{
${ }^{72}$ Representative of the Royal Egyptian Legation in London.
} 
any recommendation he may make. After discussion the motion was carried without dissent.

6. Lord Lamington proposed that the question of any change in the amount of the contribution from the London Mosque Fund towards the salary of the clerk-in-charge should be deferred and the Chairman be requested to formulate in consultation with the Honorary Treasurer, definite proposals. The proposal was carried unanimously.

Confirmed: Ampthill (Chairman) 3 November I927

\section{[Indigent Moslem Burial Fund Trust declaration]}

\section{Stamp Io/-}

THIS DEED OF DEGLARATION OF TRUST is made the nineteenth day of December one thousand nine hundred and twentyseven [ig December i927] BETWEEN the right honourable SYED AMEER ALI P.C, C.I.E., LL.D., of 2 Cadogan Place, London SWI and ABDEALI SHAIKH MAHOMEDALI ANIK of Billiter Buildings Billiter Street London $\mathrm{EC}_{3}$ of the one part and BARCLAYS BANK LIMITED of 54 Lombard Street London (hereinafter referred to as "the Trustee") of the other part

\section{WHEREAS:}

I) It is desirable to make provision for the proper burial in accordance with the rites of the Moslem Religion of indigent Moslems dying in the neighbourhood of London and elsewhere in the United Kingdom including the providing of a plot of ground a coffin and the payment of interment and other expenses and to provide for the care and upkeep of the graves of indigent Moslems in the Mahomedan Cemetery at Brookwood reserved and allotted by the London Necropolis and National Mausoleum Company for the exclusive interment of Moslems under the terms of two Agreements dated the twenty-third day of June One thousand nine hundred and fourteen and the tenth day of October One thousand nine hundred and twenty-two respectively.

2) For the purposes aforesaid the Committee hereinafter mentioned of which the said Syed Ameer Ali is the Chairman 
and the said Abdeali Shaikh Mahomedali Anik is the Honorary Treasurer and Secretary have raised a fund (to which they have themselves contributed) by public subscription and the contributions to the said fund which include the following sums of money contributed by the following persons that is to say Fifty-five Pounds by the said Right Honourable Syed Ameer Ali One Hundred Pounds by the said Abdeali Shaikh Mahomedali Anik One Thousand Pounds by His Exalted Highness Asaf Jah Nizam ul Mulk G.C.S.I., G.B.E., the Nizam of Hyderabad-Deccan One Hundred Pounds by His Highness Prince Omar Toussound Pacha of Alexandria and One Hundred Pounds by His Highness Sir Sultan Mahomed Shah Aga Khan G.C.V.O., G.C.I.E. together with other donations (after deducting amounts already paid for burials) now amount to the sum of One Thousand Four Hundred and Eighty-Seven Pounds Six Shillings and Nine Pence now standing to the credit of the account of the said Fund at the Head Office of the Trustee.

3) The said Committee have requested the Trustee to act as Trustee of the said Fund which the Trustee has consented to do.

4) It is intended that the said Fund and all other moneys hereafter to be contributed thereto shall be held and administered upon the trusts and subject to the provisions hereinafter declared and contained concerning the same.

NOW THIS DEED WITNESSETH And it is hereby declared as follows:-

Name:

I. THE said Fund and all additions thereto shall be called "the Indigent Moslems Burial Fund" and the same is hereinafter referred to as "the Fund".

Objects:

2. THE objects of the Fund are:

a) To provide for the burial of indigent Moslems dying in the neighbourhood of London.

b) Providing in special circumstances for the burial of indigent Moslems dying elsewhere in the United Kingdom but outside the neighbourhood of London. 
c) Providing kerb stones or stone slabs for or erecting monuments on the graves of indigent Moslems in the said Moslem Cemetery at Brookwood or any other Moslem Cemetery that the Committee of Management may at any time and from time to time select and for the care and upkeep of such graves and of the Cemetery in which such graves shall be situate.

3. THE Fund shall be under the control and management of a Committee which shall consist of the Chairman Treasurer and Secretary and three or more ordinary members. The members of the Committee including the Chairman Treasurer and Secretary shall not (subject as hereinafter mentioned) exceed ten in number and shall not be less than three exclusive of the Chairman Treasurer and Secretary. The office of Secretary may be combined with that of Treasurer and the duties of both offices performed by one person.

The first members of the Committee shall be:

The Right Honourable Syed Ameer Ali P.C., C.I.E., LL.D. who shall be the first Chairman.

The Right Honourable Lord Lamington G.G.M.G., G.C.I.E.

Sir Muhammad Rafique Knight Member of the Council of the Secretary of State for India.

M. Abdul Rahman Bey Fikry representing the Egyptian Legation.

Mirza Ahmad Khan Ardeshir representing the Persian Legation.

John C. Nicholson Esquire J.P and

The said Abdeali Shaikh Mahomedali Anik who shall be the first Treasurer and Secretary.

Duration of the office of members of the Committee:

4. A member of the Committee shall hold office until he shall die or resign office or reside out of the United Kingdom for a period of more than twelve consecutive months.

Vacancies in the Committee:

5. THE Committee shall have power from time to time by resolution to fill up a vacancy among the members of the 
Committee or to appoint additional members provided that the total number does not exceed ten members.

Appointment of Chairman Treasurer and Secretary:

6. THE Chairman Treasurer and secretary shall be appointed by the Committee from among their number and shall hold office for such period or periods as the Committee shall prescribe and shall be eligible for re-appointment and shall retain office until their successors are appointed. The Committee may by resolution remove any of them from office. A resolution passed by a majority of two-thirds of all the members of the Committee shall be necessary for the appointment or removal of a Chairman Treasurer or Secretary.

Meetings:

7 (i) There shall be at least one meeting of the Committee every year to consider the work of the past year and the duly audited accounts and other business.

(ii) The Secretary on instructions from the Chairman shall and any three or more members of the Committee may at any time call a meeting of the Committee.

(iii) There shall be a quorum when three members of the Committee are present.

(iv) The Chairman if present shall preside at meetings of the Committee and if at any meeting the Chairman is not present the members of the Committee present at the meeting shall appoint one of their number to act as Chairman for that meeting.

(v) At a meeting of the Committee every matter (other than the appointment of a new Chairman Treasurer or Secretary which shall require a resolution of a majority of two-thirds of all the members) shall be determined by a majority of the members of the Committee present at the meeting and voting on the question and in case of equality of votes the Chairman or acting Chairman shall have a second or casting vote. Votes may be given personally or by proxy appointed in writing but only a member of the Committee shall be entitled to act as proxy. The appointment of proxy shall be in such form as the Committee may from time to time prescribe.

(vi) Not less than seven days' notice of every meeting of the Committee shall be sent by post to every member of the Committee having an address in the United Kingdom. 
The Treasurer:

8. THE Treasurer shall keep proper books and accounts and a balance sheet shall be drawn up each year to the thirty-first day of December and shall with a list of donations and interments be circulated to such persons as the Committee shall direct.

The Secretary:

9. THE Secretary shall keep minutes of meetings and records of interments and generally deal with all clerical work incident to the administration of the Fund.

All officers to be Honorary:

Io. ALL officers i.e. the Chairmen and Treasurers and Secretary and other members of the Committee shall be appointed as honorary officers and shall perform their duties voluntarily but shall be entitled to be reimbursed all out-of-pocket expenses incurred by them in carrying out the work of the Fund.

Donations and Banking Account:

II. ALL legacies donations and subscriptions to the Fund shall be paid to the Treasurer (whose receipt shall be sufficient discharge for the same) and shall be paid by him into the capital account of the Fund. All cheques drawn on the banking or income account shall be signed by the Chairman and the Treasurer or by such other persons as the Committee shall from time to time appoint for that purpose.

The Trustee:

I2. THE Trustee shall be the Trustee of the Fund.

\section{Investments:}

I3. All moneys forming part of the Fund and requiring investment shall be invested by and in the name of the Trustee in any investment for the time being authorised by law for the investment of trust money and the Trustee shall at the request and in accordance with the directions of the Committee change such investments for others of a like nature. Such directions shall be given pursuant to resolutions from time to time passed by the Committee. 
Trust of investments:

I4. THE Trustee shall hold the investments for the time being forming part of or constituting the Fund and all additions thereto Upon trust to pay and apply and deal with the income thereof in accordance with the direction from time to time to be given to the Trustee by the Committee or of any member or members of the Committee empowered by the Committee. Such directions shall be given pursuant to resolutions from time to time passed by the Committee and the Trustee shall be entitled to act on any resolution on having a copy of the relevant resolutions purporting to be signed by the Chairman and a member of the Committee. Until otherwise directed the Trustee shall retain capital of the Fund that is the payments mentioned in Clause II hereof and shall pay the income derived from such investments into the banking account of the Fund.

Remuneration of the Trustee:

I5. THE remuneration of the Trustee shall be at the rate of One per centum per annum of the gross annual income derived from the investments for the time being forming part of the Fund and standing in the name of the Trustee but so that the Trustee shall be entitled to a minimum fee of One Guinea per annum.

Urgent matters:

I6. ALL matters regarding burial which are urgent may be dealt with by the Secretary in consultation with the Chairman and the Treasurer.

Rules:

I7. SUBJECT to the provisions of this Deed the Committee may from time to time make alter and rescind rules for the administration and management of the Fund and the carrying of the objects of the Trust into full effect and in particular (but without limiting or restricting the generality of their powers in this respect) for the conduct of and arrangements for funerals in accordance with the Mahomedan rites and the powers and duties of the Secretary with regard thereto the amount so to be expended in each particular case whether or fixed or varying amounts and the keeping of accounts in relation thereto and the forms to be prescribed for applications for burials at the cost of the Fund. 
IN WITNESS whereof the parties hereto of the first part have hereunto set their hands and seals and the Trustee has caused its Common Seal to be hereto affixed the day and year first above written.

SIGNED SEALED AND DELIVERED by the above-named The Right Honourable Syed Ameer Ali P.C., G.I.E., LL.D. in the presence of

(Miss) Ethel P. Holden $4^{2}$ Chestnut Road Plumstead SE I8, Clerk in Charge.

SIGNED SEALED AND DELIVERED by Abdeali Shaikh Mahomedali Anik in the presence of

Henry Edward Davenport

Sheriff of City of London, Justice of the Peace.

THE COMMON SEAL of Barclays Bank Limited was hereto affixed in the presence of

W.S Gurney Director

Hugh Carroll Assistant Secretary 63492

[Seal of Barclays Bank Limited]

\section{A meeting of the Trustees and of the Executive Committee of the London Mosque Fund was held at 3.45 p.m on Thursday 3 November 1927 at 2 Cadogan Place SWI}

\section{Present:}

The Rt Hon Lord Ampthill (in the Chair)

The Rt Hon Ameer Ali

Mr A.S.M. Anik (Hon Treasurer)

I. The Minutes of the meeting held on the 3i December 1927 [added in text: 1926?] were read and confirmed.

2. In connection with the Minutes Mr Ameer Ali explained that the number of worshippers attending the Namaz-gah had become considerably fewer, and in consequence of the fall in their number it was considered by the Trustees desirable not to pay such heavy rent as was demanded by Messrs G.N. Watts Ltd for in I Campden Hill Road. Notice was accordingly given to terminate the tenancy on 
the I I November 1927 with the final payment of a half-quarter's rent namely $\mathcal{E}^{\mathrm{i} 6-5}$.

As the promoters of the Woking Muslim Mission desired to continue the tenancy for their own work, the Trustees had agreed to the payment of $£ 60$ per annum, payable quarterly, to the Pesh Imam for the maintenance of the Friday prayers on condition that he made proper arrangements for their performance and reported periodically to the Trustees as to the number of worshippers attending the Namazgah.

The payments of $£_{1} 6-5$ and $£_{1} 5$ were duly authorized.

3. A letter from Khwaja Kamal-uddin dated 30 August I927 was read regarding the proposal put forward by him and Lord Headley for the collection of funds throughout India and other places for the London Mosque Fund, in conjunction with the funds of the Muslim Mission. ${ }^{73}$ After a full discussion it was

Resolved:

that a reply be sent to Khwaja Kamal-uddin and Lord Headley to the effect that the Trustees thank them cordially for the offer to cooperate in the collection of funds for the London Mosque, but the Trustees greatly regret that they are precluded by their constitution from contributing to the expenses of the scheme proposed by Khwaja Kamal-uddin and Lord Headley.

Addendum

I. The following Resolution in regard to the furniture at III Campden Hill Rd was passed by correspondence:

Resolved:

That the Honorary Treasurer be instructed to write off the item of furniture at II I Campden Hill Road now standing in the account at E6o-I4-I, and that the same be made over to the Woking Muslim Mission for the use of the worshippers at the Friday prayers etc.

I8.I I. 27 Ameer Ali

\footnotetext{
${ }^{73}$ In April 1927, Ameer Ali issued a fresh appeal to 'Moslem rulers, and the great and wealthy princes and magnates' to subscribe funds to endow 'a fitting place of worship in the capital of the British Empire'. In his view, 'The small mosque in Woking does not serve as the symbol of the dignity of the Moslem faith; it is also not available to Moslem residents in London for the daily prayers enjoined by their faith' (see The Times, 26 April I927).
} 
2I. II. I927 [unclear text]

Confirmed: Ameer Ali i March I928

\section{Copy attached to the minutes:}

Hyderabad Deccan

LCC Ameerali 2 Cadogan Place London

Nizam gives five lakhs ${ }^{74}$ to Lord Headley's London Nizamiah Mosque will your trust cooperate with him and you now join him as trustees - Aminjung

\section{Copy reply sent:}

8 February 1928

Sir Amin Jung Hyderabad Deccan

Apologise for delay due consultation with other Trustees. We offer respectful thanks to his Exalted Highness for munificent donation five lakhs for London Mosque Fund. Our appeal of Ioth May Ig27 to His Exalted Highness suggested name Nizamiah for London Mosque. We shall be glad to have Lord Headley as co-trustee we pray that donation be remitted direct to Bank of England to credit of London Mosque Fund

Ameerali

\section{Copy:}

Hyderabad Deccan

LCC Right Hon Ameer Ali 2 Cadogan Place London

Select Committee Nizam's council considered your cablegram etc. We propose new Trust with Lord Headley as chairman who has undertaken onerous task of going about personally to collect funds. Other Trustees, yourself, Lords Ampthill and

\footnotetext{
${ }^{74}$ One lakh $=$ I00,000; thus I00,000 rupees in this context.

${ }^{75}$ The Nizam donated the money $(£ 60,000)$ on the condition, it appears from the telegram, that a Trust, separate from the LMF, should be set up, and the name of the mosque be the Nizamiah Mosque. The Nizamiah Mosque Trust was duly formed and a trust deed was executed and registered in India as well as with the Charity Commissioners in Britain. In I935 the surviving members were Lord Headley, the Aga Khan, Nawab Mehdi Yar Jung (Political Member of the Nizam's Government), and Dr S.S. Mohamedi (see The Times, Io January 1935).
} 
Lamington from your Trust, and Sir Abbas Ali Baig, Khwaja Kamaluddin from Lord Headley's trust and one Trustee representing Nizam. All three Trusts to cooperate cordially for attaining common object of erecting absolutely non-sectarian Nizamiah Mosque in London. Kindly cable reply - Amin Jung.

\section{Copy reply sent 18 February 1928 :}

DLT Sir Amin Jung Hyderabad Deccan

Will gladly consider your proposal but request time as Trustees meeting immediate impossible owing to absence on continent principal members - Ameerali

\section{A meeting of the Trustees of the London Mosque Fund was held at 3.45 p.m 2 Cadogan Place SWi on Thursday I March 1928}

\section{Present:}

The Rt Hon Ameer Ali (in the Chair)

The Rt Hon Lord Ampthill

The Rt Hon Lord Lamington

Sir Mohamed Rafique

I. The minutes of the meeting of the Trustees and Executive Committee held on 3 November 1927 were read and confirmed.

2. Read telegrams from Sir Amin Jung dated Hyderabad 6 February and I2 February I928 and respective replies thereto dated 8 February and I8 February I928.

3. Read copy of letter to His Exalted Highness the Nizam dated i8 May I927 in which the Trustees of the London Mosque Fund suggested name "Nizamiah Mosque" and read also the reply of His Exalted Highness to it.

4. The Question of the reply to Sir Amin Jung's telegram was fully discussed and it was resolved that the following telegram be sent:

"Replying your telegram Trustee"

"London Mosque Fund glad to co-operate and to depute Ameerali and Lords Lamington and Ampthill to represent them on the new Trust His Exalted Highness proposes to form - Ameerali" 
5. As Reuter's representative was seeking an interview in order to obtain information regarding the donation of five lakhs of rupees by His Exalted Highness for the Mosque in London, the following statement was drafted and unanimously agreed to:

"The Trustees of the London Mosque Fund have agreed to depute representatives to act with the Trustees for the Fund of five lakhs of rupees donated by His Exalted Highness the Nizam with a view to cordial co-operation for the common object of erecting an absolutely non-sectarian Mosque in London. That has always been the purpose of the London Mosque Fund. The Trustees of the London Mosque Fund have proposed to His Exalted Highness the Nizam that the Mosque should be styled the "Nizamiah Mosque."["]

6. The payment for the present in advance of the London Mosque Fund contribution of $\mathcal{E}_{\mathrm{I}} 5$ (fifteen pounds) per quarter towards the maintenance of the Friday worship at in Campden Hill Road was agreed to.

Confirmed: Ampthill (Chairman) 9 October 1928

\section{A meeting of the Trustees and of the Executive Committee of the London Mosque Fund held by kind permission of Lord Ampthill at his office 17 Piccadilly, W, on Friday 9 October 1928 at 5 pm}

Present:

The Rt Hon Lord Ampthill (in the Chair)

Sir Mohamed Rafique

Sir Thomas Arnold (Hon Secretary)

Mr A.S.M. Anik (Hon Treasurer)

Mr Mirza Ahmad Khan Ardeshir

I. The minutes of the meeting of the Trustees held on I March I928 were read and confirmed.

2. After discussions as to the future signing of cheques, it was resolved:

In view of the lamented death of the late Right Hon Ameer Ali the resolution of 7 June 1926 be modified as follows, viz: that all cheques and instructions be signed by any one of the following: 
The Rt Hon Lord Lamington

The Rt Hon Lord Ampthill

Sir Mohammed Rafique

Being Trustees of the London Mosque Fund, and counter-signed by the Hon Treasurer, Mr A.S.M. Anik.

3. Instructions were given for a letter to be drafted for the bank of England embodying this resolution and sent to Lord Ampthill for his signature.

4. A cheque for $£$ io being the London Mosque Fund proportions of the rent of i8 Sloane Street for the September quarter was authorised to be drawn.

5. The Hon Treasurer explained that six months' notice had been given to the landlord of 18 Sloane Street by the British Red Crescent Society to vacate the front office of the suite rented by them, and that by arrangement all the future and effects had been moved into the Committee Room at the same address. The question of the London Mosque Fund proportion of the future rent was discussed, and it was resolved

to continue in occupation of the premises at i8 Sloane Street until the expiration of the six month's notice on the same conditions as hitherto, viz: one-third of the rent per annum, payable quarterly as heretofore.

6. Read letter from two English Muslims regarding the conduct of the Friday prayers at in Campden Hill Road, and attendance thereat. Following discussion as to the contribution towards the rent of the Namaz-gah of $£$ I5 per quarter, it was resolved

to discontinue contributions towards the holding of Friday prayers at I I I Campden Hill Road. And that the resolution passed at the meeting of the Trustees and Executive Committee on the 23 November I927 be and is hereby cancelled.

The Hon Secretary was instructed to communicate with the PeshImam of the Woking Mosque to this effect, and the Hon Secretary was instructed to make no further payments in respect of the contribution.

7. The Hon Treasurer enquired whether the Trust Deed executed last year had been registered at Somerset House, and the Hon Secretary was instructed to write to the solicitors Messrs Withers Co. about this, and if it had not been so registered to enquire whether such a formality was necessary. 
8. As regards a Trustee to take the place of the lamented Rt Hon Ameer Ali, the Hon Secretary was instructed to write to His Highness the Aga Khan for his suggestions as to whom the Trustees might approach to join the Board.

9. The meeting closed at $6.15 \mathrm{pm}$

Confirmed: Aga Khan 9January I93I

\section{A meeting of the Trustees and of the Executive Committee of the London Mosque Fund was held on 9 January I93I at I 2.I5 pm at the Ritz Hotel, Piccadilly, London, WI}

\section{Present:}

$\mathrm{H} \mathrm{H}$ the Aga Khan (Chairman)

The Rt Hon Lord Ampthill

The Rt Hon Lord Lamington

Col Nawab Malik Sir Umar Hayat Khan* ${ }^{* 6}$

Mr Waris Ameer Ali*

Mr M.K. Atabeki (ist Secretary Persian Legation)

Mr A.S.M. Anik (Hon Treasurer)

I. The Minutes of the last meeting held on 9 October 1928 were read and confirmed.

2. $\mathrm{H} \mathrm{H}$ the Aga Khan expressed regret at the loss the Fund had sustained by the deaths of Mr Muhammad Rafique, one of the Trustees who had given valuable help, and Sir Thomas Arnold who had been Hon Secretary from the commencement of the Fund, and proposed that a record be made in the Minutes. The proposal was seconded by Lord Ampthill.

3. It was proposed by $\mathrm{H} \mathrm{H}$ the Aga Khan and seconded by Lord Ampthill that Sir Umar Hayat Khan and Mr Waris Ameer Ali be appointed trustees in place of the late Rt Hon Syed Ameer Ali and the late Sir Muhammad Rafique. The same was unanimously approved and they were duly appointed.

\footnotetext{
${ }^{76}$ Sir Mahomed Umar Hayat Khan Tiwana.
} 
4. In view of the fact that the Securities were standing in the Name of the sole survivor, Lord Lamington, it was proposed by him and seconded by Mr A.S.M Anik that they be transferred in the joint names of Lord Lamington, Sir Umar Hayat Khan and Mr Waris Ameer Ali, and the forms relative thereto were duly signed and completed.

5. Regarding the future singing of cheques, it was resolved

that in view of the lamented death of the late Sir Muhammad Rafique and the late Rt Hon Syed Ameer Ali, Col Nawab Malik Sir Umar Hayat Khan, Tiwana, K.C.I.E, C.B.B.E, M.V.O, A.D.C, and $\mathrm{Mr}$ Waris Ameer Ali, I.C.S, (Retd), be appointed Trustees in their place, therefore the Resolution of the 9 October 1928 be altered as follows, viz:

that all cheques and instructions be signed by any one of the following:

The Rt Hon Lord Ampthill

The Rt Hon Lord Lamington

Sir Umar Hayat Khan

Mr Waris Ameer Ali

Being Trustees of the London Mosque Fund and countersigned by the Hon Treasurer Mr A.S.M. Anik

6. A letter to the Bank of England embodying this Resolution was signed by the Chairman and also by the above mentioned four Trustees and Hon Treasurer.

7. Two specimen cards for the Bank of England were signed by the two new Trustees, Sir Umar Hayat Khan and Mr Waris Ameer Ali and witnessed by the Chairman.

8. The Account to 3I December I930 was presented by the Hon Treasurer and passed.

9. It was proposed by the Chairman and seconded by Lord Lamington that in view of the fact that the value of the India $31 / 2 \%$ securities had considerably depreciated since their purchase before the War the investments be entered at the present value and the difference written off.

Io. It was proposed by the Hon Treasurer and seconded by Lord Ampthill that a further $\mathcal{E}^{1} 200$ face value India $3 \frac{1}{2} \%$ be purchased.

II. The Report for the year I930 was read and approved.

I2. The [illegible] presented to the late Rt Hon Syed Ameer Ali was brought from the bank. After discussion as to the best means of using 
the same it was proposed by $\mathrm{H} \mathrm{H}$ the Aga Khan and seconded by Lord Ampthill that it be kept for the time being at the bank.

I3. It was proposed by the Chairman and seconded by Lord Lamington that the question of utilization of the Fund be held over for a period of six months to give the new Trustees Sir Umar Hayat Khan and Mr Waris Ameer Ali an opportunity of investigating the matter and making proposals.

I4. It was proposed by the Chairman and seconded by Lord Lamington that Mr A.S.M Anik combine the office of Hon Secretary with his present office of Hon Treasurer, and he was accordingly appointed Secretary for one year.

I5. The meeting closed at I.20 pm

Confirmed: Lamington 26 Feb I93 I

$\mathrm{HH}$ the Aga Khan expressed the view that the funds of the London Mosque Fund should on no account be handed over to any other body. This was unanimously agreed to. L. 26 February I93I

\section{A meeting of the Trustees and of the Executive Committee of the London Mosque Fund was held on Thursday 26 February 1931 at 12 noon at Lord Lamington's House, 3, Wilton Place, London S.W. I}

Present:

The Rt Hon Lord Lamington (Chairman)

The Rt Hon Lord Ampthill

Col Nawab Malik Sir Umar Hayat Khan

Mr Waris Ameer Ali

Mr R.A Radi (2nd Scy. Egyptian Legation)

Mr A.S.M. Anik (Hon Treasurer)

I. The Minutes of the last meeting held on 9 January were read and confirmed.

2. The account to 3I January I93I audited by Messrs Feasey, Hull and Hornsby, Chartered Accountants, was presented by the Hon Treasurer and passed for printing.

3. A report of the Fund's activities to date was presented and passed. 
4. Letters received from Mr Syed Hashimi ${ }^{77}$ dated London I3 August I93I and Hyderabad 6 January I93I addressed to the Hon Treasurer Mr A.S.M Anik were carefully considered. It was proposed by Sir Umar Hayat Khan and seconded by Lord Ampthill that the proposals made by Mr Hashimi be accepted and the same was unanimously agreed, viz:

I. The London Mosque Fund is only to provide a suitable small building as a Mosque and Religious School in the East End of London, to be named after the late Rt Hon Syed Ameer Ali.

II. The organisers at Hyderabad will make proper and permanent provision for the appointment of a good instructor and Imam and will also bear all other current expenses of the projected institution.

It was decided to send a letter and cable to Mr Hashimi as per copies attached. Mr Hashimi's original letters are also attached.

5. A telegram was received by the Hon Treasurer from $\mathrm{H} \mathrm{H}$ the Aga Khan as follows: "Approve letter and cable drafts enclosed in your letter 23 February. Please proceed."

6. It was suggested by Mr A.S.M Anik that for the convenience of the Trustees and members of the Executive Committee, important matters should be circulated by letter and their views expressed in writing, and if absolutely necessary a meeting be called. This was unanimously agreed to.

7. The meeting closed at I.I5 pm.

Confirmed: Lamington i7 April i93I

\section{$\underline{\mathbf{8 6 6}}^{7^{8}}$}

\section{London Mosque Fund Report}

The absence of a fitting Mosque in the Metropolis of the British Empire is felt acutely by all Moslems coming to England on business

\footnotetext{
${ }^{77}$ Syed Hashimi was the Nizam of Hyderabad's representative visiting London on a fact-finding trip.

${ }^{78}$ The number ' 786 ' is a numerological value for 'Bismillah ar Rahman ir Rahim'; it is used in this text as a heading. However, some Muslims think that the use of this number is an improper 'innovation' (bidah in Arabic) and therefore believe that it should not be used. Opinions remain divided on the issue.
} 
or for pleasure. In order to supply this want the London Mosque Fund was organised in Igı by $\mathrm{H} \mathrm{H}$ the Aga Khan, the late Rt Hon Syed Ameer Ali and others. It received the support of many prominent Moslems throughout the Moslem world.

The Tripolitan War ${ }^{79}$ which broke out in I9II, the Balkan War of I9I $-{ }^{2} 3^{80}$ and later the World War of I9I4-I8 interrupted the further prosecution of the Executive Committee's efforts to collect funds. The deaths of the Rt Hon Syed Ameer Ali, whose great wish it was to build a Mosque in London, Sir Muhammad Rafique another Trustee, and also Sir Thomas Arnold who acted as Secretary of the Fund from its commencement have delayed the fulfilment of the object.

With the income from the investments the Executive Committee maintained for Prayers a temporary place of worship for the followers of Islam. ${ }^{81}$

A meeting was held on the 9 January I93I under the chairmanship of $\mathrm{H} \mathrm{H}$ the Aga Khan, at which Col Nawab Malik Sir Umar Hayat Khan, Tiwana, and Mr Waris Ameer Ali were appointed Trustees in place of the late Rt Hon Syed Ameer Ali and Sir Muhammad Rafique. There are now five Trustees, viz:

H H the Aga Khan, G.C.S.I, G.C. I.E, G. G.V.O, The Rt Hon Lord Ampthill, G.C.S.I, G.C.I.E, The Rt Hon Lord Lamington, G.G.M.G, G.C.I.E, Col Nawab Malik Sir Umar Hayat Khan, Tiwana, K.C.I.E, G.B.B.E, M.V.O, A.D.C,

Mr Waris Ameer Ali I.C.S (Retd)

It is hoped with the assistance of Moslems in India that the object of the Fund will be fulfilled.

The Accounts have been audited by the Charted Accountants and it will be observed that from the 9 November 1930 to 3 I January I93I

\footnotetext{
${ }^{79}$ The Tripolitan War between the Ottoman Empire and the Kingdom of Italy began on 29 September I9II and ended on I8 October I9I2 with the signing of the Treaty of Lausanne, which awarded Italy control of the north African Ottoman provinces of Tripolitania, Fezzan, and Cyrenaica (present day Libya). See http://www. britannica.com/EBchecked/topic/297469/Italo-Turkish-War (accessed on 9 April 20Io).

${ }^{80}$ The Balkan War was fought between the Ottoman Empire and the Balkan League, a coalition of Serbia, Bulgaria, Greece, and Montenegro. The defeated Ottoman state concluded the peace treaty in London on 30 May I9I3, which resulted in the loss of almost all of its European territory. See http://www.britannica.com/EBchecked/topic/5030o/ Balkan-Wars (accessed on 9 April 20I0).

${ }^{81}$ Premises had first rented been in 39 Upper Bedford Place and then in II I Campden Hill Road.
} 
the total donations received are $f_{6069-3-4}$. This sum with part of the income has been invested in securities inscribed in the Bank of England, costing \&7900-I2-7. The India $3 \% \frac{1}{2} \%$ Securities which were bought before the War have considerably depreciated in value and the Trustees therefore passed a Resolution to write off the depreciation, fir85-9-3, from the surplus income, which is shown in the Balance Sheet. The total expenditure for holding prayers, etc. from November I9Io to March I929 was $£ 2362-5-9$, which has also been paid out of income, and the donations received remain intact.

Lamington Chairman

A.S.M Anik Treasurer

London 26 February I93I

\section{POST OFFICE TELEGRAPHS}

I84 Cannes i6309-20-20-I620

ANIK BILLITER BUILDINGS BILLITER STREET LONDON APPROVE LETTER AND CABLE DRAFTS ENCLOSED IN YOUR LETTER 23 FEBRUARY PLEASE PROCEED = AGA KHAN

\section{LONDON MOSQUE FUND EXPENSES}

As per Audited Account.

9th Nov igro to 3i Dec 1923

$\mathcal{E} 1538-$ Iо - Iо

Less grant for Brookwood Cemetery

E $105^{-}$Iо - Iо

I Jan I924 to 3I Dec I926

£ $575^{-} 6-$ II

I Jan I927 to 3I Dec I928

f $340-12-6$

I Jan I929 to March I929

E I2- I5- 6

E $2362-+5-29$ 


\section{Registered}

Syed Hashimi Esq

26 February I931

Red Hill

Hyderabad-Deccan

Dear Sir

Your letters dated London I3 August 1930 and Hyderabad 6 January I93I addressed to me (A.S.M Anik, Treasurer of the London Mosque Fund) have been placed before the Board of Trustees, H H the Aga Khan, the Rt Hon Lord Ampthill, the Rt Hon Lord Lamington, Col. Nawab Malik Sir Umar Hayat Khan, and Mr Waris Ameer Ali. They have carefully considered the contents and agree to the proposals made therein, viz:

I. The London Mosque Fund is only to provide a suitable small building as a Mosque and Religious School in the East End of London, to be named after the late Rt Hon Syed Ameer Ali.

2. The organisers at Hyderabad will make proper and permanent provision for appointment of a good instructor and Imam and will also bear all other current expenses of the projected institution.

On the part of the London Mosque Fund, a representative will occasionally visit the Institution and make such reports as may be necessary and desirable.

Any other assistance in this project will be gladly given except financial support, as our fund is not sufficient to do so.

We should like to know the names of the respective parties and full details of the arrangements made. As you are no doubt aware, in this country the majority of payments are made weekly therefore proper financial arrangements should be made on your side. The salary etc. of the Imam who will be engaged by you will be known to you but the current expenses in London cannot at present be estimated, until a test of about six months or a year's expenditure.

The Trustees of the London Mosque Fund hope that the proposed project will be successful and a permanent establishment.

Yours faithfully

For and on behalf of the LONDON MOSQUE FUND

A.S.M Anik Hon Treas. and Secy. 
p.s the following cable has been sent to you today:

LONDON MOSQUE FUND TRUSTEES AGREE TO PROPOSALS IN YOUR LETTERS THIRTEENTH AUGUST SIXTH JANUARY NAMELY LONDON MOSQUE FUND TO PROVIDE SMALL BUILDING AS MOSQUE AND ALL OTHER FINANGIAL ARRANGMENTS INCLUDING IMAM TO BE PROVIDED BY THE ORGANISERS AT HYDERABAD TRUSTEES GLAD TO ASSIST IN EVERY POSSIBLE WAY DETAILED LETTER POSTED TODAY - ANIK.

26 February I93I

$5^{\mathrm{I}}$

I I O

DLT SYED HASHIMI

REDHILL HYDERABAD-DEGGAN

LONDON MOSQUE FUND TRUSTEES AGREE TO PROPOSALS IN YOUR LETTERS THIRTEENTH AUGUST SIXTH JANUARY NAMELY LONDON MOSQUE FUND TO PROVIDE SMALL BUILDING AS MOSQUE AND ALL OTHER FINANCIAL ARRANGMENTS INCLUDING IMAM TO BE PROVIDED BY THE ORGANISERS AT HYDERABAD TRUSTEES GLAD TO ASSIST IN EVERY POSSIBLE WAY DETAILED LETTER POSTED TODAY - ANIK.

c/o Haira Trading Co 66 Mark Lane

London E.C 3

I3 August I930

A.S.M. Anik Esquire:

Billiter Buildings

Billiter Street

E. $\mathrm{C}_{3}$

My Dear Mr Anik

It is, as you know, the East End parts of London where a number of poor Muslims have permanently settled. They have married English wives and established different trades of their $\mathrm{own}^{82}$ on something of

\footnotetext{
${ }^{82}$ For examples of such trades, see Appendix III.
} 
a permanent basis. The number of such families is, so far as I am able to judge, not less that fifty, while there are always scores of Muslim Lhaskars $^{8_{3}}$ etc. employed by Navigation Companies temporarily staying in the same locality. These are the people who need most to have a Mosque and some provision for the religious instruction of their children who shall other wise inevitably drift towards-Christianity or $^{8_{4}}$ irreligion; and as a private Muslim I will on my return to India, try my best to persuade charitable trusts or individuals to interest themselves in the matter. But the first thing that strikes me as not altogether irrelevant in this connection is to approach you with the suggestion whether it will be possible for your London Mosque Committee, who I believe have considerable funds subscribed for building a Mosque in London, in their custody to undertake to establish a Mosque and school in the East End? The project of constructing a grand building ${ }^{85}$ may now be left to the Nizamia Mosque Board and your funds might suitably be utilised in satisfying a real religious need of the poor but permanent Muslim Colony of London.

On making enquiries and visiting a number of houses I think it may be quite possible to get a building containing halls for congregation, instruction and other rooms that might bring in a small income to meet the maintenance charges of the Mosque, for a sum not exceeding $£ 3$, ooo. This amount, I imagine, you could easily devote for the purpose and commemorate the great services of the late Syed Amir Ali in the Cause of Islam by naming it the "Amir Ali Mosque", while it should not be difficult to find some Indian endowment or Mosque Trust to cooperate with you by undertaking to send an efficient Imam and Instructor at their own expense, acting in London under your Committee's supervision. The scheme appears to me worthy of your Mosque Fund Committee's consideration, as they, I venture to think,

\footnotetext{
${ }^{83}$ Usually spelt as 'lascar', this term (which comes from the Persian/Urdu Lashkar, meaning military camp or army, and al-askar, the Arabic word for a guard or soldier) was used to describe maritime manual workers, primarily from India, employed on British-owned ships on non-European contracts, with unfavourable conditions, and at a fraction of the wages of their British counterparts. Rozina Vizram's study, Ayahs, Lascars and Princes: the story of Indians in Britain, ${ }^{1700-1947}$ (London, 1987), explores the experiences of these migrant seamen in the nineteenth and early twentieth centuries.

${ }^{84}$ It is interesting that this was struck through, along with a few grammatical errors. It would appear that - to the writer of this Minute at that time - 'irreligion' represented a threat, but 'Christianity' per se did not.

${ }^{85}$ Even at this stage, the 'Nizamia' mosque was viewed as something grand, while the East London Mosque, on the other hand, was perceived in a totally different light, a 'chapel' as opposed to a 'cathedral'. See Hassan Suhrawardy's comments as chairman of the LMF from the late I93os, available in correspondence held at the ELM Archives.
} 
would hardly prefer to keep the funds continue to lie idle rather than be serving the religious purpose they were subscribed for.

I shall feel much obliged to you if you could kindly communicate to me the official decision of your Committee as early as convenient to you on the subject.

With best regards

I remain

Yours Sincerely

Syed Hashimi

I4 August 1930

Syed Hashimi Esq.

c/o Haira Trading Co.

66 Mark Lane

London E.C 3

Dear Mr Hashimi

I thank you for your letter of the 13 inst. and note the proposal contained therein. The Trustees of the London Mosque Fund are at present out of Town but I have sent copies of your letter to them for their consideration.

With kind regards

Yours Sincerely

A.S.M Anik

The Rt Hon Lord Lamington G.C.M.G, G.C.I.E

Lamington

Lanarkshire

\section{$\underline{\text { London Mosque Fund }}$}

I enclose herewith copy of a letter received from Syed Hashimi and also copy of my reply. This gentleman has been to see me twice and I understand that he has come as a private representative of H.E.H the Nizam to investigate the matter of the proposed Nizamiah Mosque and the conditions of Muslims in London and other places in the United Kingdom and to report to His Exalted Highness. 
The proposal contained in Mr Hashimi's letter practically coincided with the one I had in view as mentioned in my letter to your Lordship dated 6 December I929.

I send a further copy of his letter and my reply as you may wish to send same to Lord Ampthill. If Your Lordship and Lord Ampthill favourably consider the proposal then $\mathrm{H}$. $\mathrm{H}$ the Aga Khan will have to be approached, and a meeting of the Executive Committee, which includes representatives of the Persian and Egyptian Legations, called.

I have sent a copy of Mr Hashimi's letter to Sir Umar Hayat Khan who has great sympathy and interest with Muslim affairs. He has agreed to become one of the trustees and his co-operation will be useful.

With kind regards

I remain, My Lord, Yours Sincerely

A.S.M Anik

\section{Red Hill}

Hyderabad (Deccan)

6 Jan I93I

\section{Dear Mr Anik}

I am sorry I was too busy to have written to you earlier though I safely arrived in my station toward the end of November. You will be, however, glad to learn that I have already succeeded here in receiving definite promises of support for the proposed establishment of a religious School and Mosque in the East End of London, and we are now only awaiting the safe return of the Hyderabad Delegation before taking any practical steps for the consummation of the project; particularly so, as we expect Sir Mohammed Akbar Hyderi might have a good occasion to study Islamic needs on the spot during his stay in London. In the meantime I shall very much welcome to receive the decision of your Mosque Fund Committee in this regard as promised by you in your letter to me dated I4 August I930. If you were willing to devote even half of this fund to buy or construct a suitable small building for the afore-said purposes... possibly transferring the rest of the money to the Indigent Burial Fund which you have so philanthropically instituted, we on our part will have only to make proper and permanent provision for the appointment of a good instructor and Imam as well as other current expenses of the projected institution. Any other ways, of your cooperation that you 
may think fit to suggest we shall only too gladly consider, and I may directly write to your chairman of the Committee if you so advise. But in case we do not hear anything from you up to the end of March we shall naturally conclude you do not propose to take any action in the matter and that we should proceed with our scheme independently.

With best wishes for a happy New Year and kindest regards

I remain Yours Sincerely

Syed Hashimi

[Letter date-stamped 26 Fan I93I]

Syed Hashimi Esq.

27 January I93I

Red Hill

Hyderabad (Deccan)

Dear Mr Hashimi

I have received your letter dated Hyderabad 6 January i93I and have sent a copy of the same to each of the Trustees of the London Mosque Fund, viz.

H.H the Aga Khan

The Rt Hon Lord Ampthill

The Rt Hon Lord Lamington

Sir Umar Hayat Khan, Tiwana

Mr Waris Ameer Ali

for their consideration, and I will communicate to you further in due course.

With kind regards

Yours Sincerely

\section{Red Hill}

Hyderabad (Deccan)

24 March I93I

Dear Mr Anik

I hasten to acknowledge with thanks the receipt of your official letter dated 26 February I931, containing the decision of the London Mosque Fund Trustees in favour of providing from their own fund 
"a suitable small building as a mosque and Religious School in the East End of London, to be named after the late Rt Hon Syed Amir Ali”.

Owing to some error of the local Post Office the letter was delayed a week in delivery and was received after your later communication of the 2 Instt. Hence the delay in my reply.

I am naturally happy to see my humble suggestion unanimously accepted by your Board of trustees, and though you do not specify the sum of money the Trustees would be willing to devote for the Mosque building, I venture to presume it will not be less than $£_{3}$, ooo as suggested in my first letter of I3 August i930 to you.

On our part a strong Board of Management for Amir Ali Mosque, London, has already been formed consisting of the following:

I) Nawab Mehdi Yar Jang*

2) Nawab Fakhr Yar Jang*

3) Nawab Zulqadr Jang

4) Nawab Mohammed Yar Jang

5) Mr Marmaduke Pickthall*

6) Mr Syed Hashimi

All of them, with the exception of your humble correspondent happen to be some of the most prominent people in Hyderabad, while $\mathrm{Mr}$ Pickthall has kindly consented to act as Hon Secretary to the Board and will henceforward take charge of all correspondence \&ct [sic] pertaining to the project.

A petition is being submitted to the Hyderabad Government for a grant of $£ 600$, estimated sufficient to provisionally cover the current expenses of the proposed Mosque and School for one year; but as soon as the scheme takes practical shape, steps will be taken to found a permanent Endowment Trust in London for the purpose.

Concluding, may I take the opportunity to express feelings of my personal indebtedness to you for kind interest you have throughout shown in regard to my humble proposal and beg to remain,

Very Sincerely Yours

Syed Hashimi

[handwritten] to A.S.M Anik Esq. Billiter Buildings, London E.G 3 
A special meeting was held on Friday 17 April r931 at 2.30 pm at the Waldorf Hotel, Aldwych, London W.C 2. The Rt Hon Lord Lamington, G.C.M.G, G.C.I.E presided

Present:

The Rt Hon Lord Lamington (Chairman)

The Rt Hon Lord Ampthill

Sir Umar Hayat Khan, Tiwana

Mr A.S.M. Anik (Hon Treasurer and Secretary)

I. The minutes of the last meeting held on 26 February I93I were read and confirmed.

2. A letter from Mr Syed Hashimi, Hyderabad, attached herewith was discussed and it was decided to reply to him as per copy attached.

3. The meeting was closed at $3 \mathrm{pm}$.

Note: Mr Waris Ameer Ali arrived after the close of the meeting. Sir Umar Hayat Khan explained to him the decision of the meeting, to which he agreed. A copy of the minutes has been forwarded to him and to the other Trustees.

Confirmed: Lamington 7 April $193^{2}$

Copies sent to The Aga Khan, Lord Lamington, Lord Ampthill, Sir Umar Hayat Khan, Waris Ameer Ali. Also copy of Minutes

Letter registered 23 April I93I

2I April I93I

Syed Hashimi

Red Hill

Hyderabad-Deccan

Dear Mr Hashimi

\section{$\underline{\text { London Mosque Fund }}$}

I thank you for your letter of the 24 March I93I which I placed before the Board of Trustees at a special meeting held on Friday last i7 April.

We note with pleasure the distinguished names on your Board of Management for the proposed Amir Ali Mosque and Religious School in the East End of London, and that Mr Marmaduke Pickthall who is 
known to the undersigned and others will act as Secretary. His recent publication of a translation of the Koran ${ }^{86}$ is a valuable work and we congratulate him.

We note that you have submitted a petition to the Hyderabad Government for a grant of $£ 600$ for a year's current expenses and that as soon as the scheme takes practical shape you will take steps to found a permanent Endowment Trust in London for the purpose.

On our part, as soon as the Grant of $£ 600$ is made a building will be rented for the purpose, and when the permanent Endowment Trust is founded in London the London Mosque Fund will allocate the sum of $£ 3000$ (three thousand pounds) for the Amir Ali Mosque and Religious School in the East End of London.

Our Board considers that the scheme should be established on a firm footing to ensure its permanence.

We hope to hear shortly what further arrangement you have made.

I remain, Yours Very Sincerely

Hon Treasurer and Secretary

Hyderabad

Deccan

I6 June I93I

[handwritten letter, stamped: 6 July I93I]

Dear Mr Anik

I am sure you must be anxious to know what is happening here with regard to the Syed Ameer Ali Mosque project. A committee was formed and we put up a petition that part of the interest ${ }^{87}$ on the Nizamia Mosque Fund money might be applied to this purpose. After considerable delay we have been told that there is some objection to such an arrangement and that we should apply to the government for a new grant altogether. This we are going to do as soon as our great ones, some of whom are members of the committee and others friendly members of the Government, have returned from the hills.

This is a city of delay. To you who have lived so long in London our inevitable habit of procrastination will seem exasperating, but I

\footnotetext{
${ }^{86}$ Marmaduke Pickthall's translation of the Qur'an was published in I930.

${ }^{87} \mathrm{At}$ this point in time there seems to have been no religious objection either to the taking of interest $(r i b a)$ or to its use, both of which have been considered by many Muslim jurists to be prohibited under Islamic law.
} 
${ }_{15} 6$

believe that the intention is to do something, and that something will eventually be done in this case.

With very kind regards, believe me,

Yours Ever

M. Pickthall

9 July i93 I

Marmaduke Pickthall Esq

Civil Service House

Hyderabad-Deccan

Dear Mr Pickthall

$\underline{\text { Mosque and Religious School in the East End of London }}$

I have duly received your letter of the I6 June and have communicated the contents of same to the Trustees of the London Mosque Fund.

I quite understand the cause of the delay in this letter.

I note that you have made a fresh application to the Hyderabad Government for a grant and we shall be pleased to hear in due course what has been done. In our opinion it is advisable to keep this undertaking quite separate from the Nizamiah Mosque Project.

With Kind Regards

Yours Sincerely

Hon Treasurer

London Mosque Fund

24 November 1931

Syed Hashimi Esq

Red Hill

Hyderabad-Deccan

Dear Mr Hashimi

\section{London Mosque Fund}

I have before me your letter of the 24 March 193I to which I replied on 2I April. Since then I have not heard from you. 
Regarding the proposed Mosque and Religious school in the East End of London, no arrangements have been made and we are waiting to hear from your side.

The year is nearing its close and I shall have to submit a report to the Trustees. I shall be very pleased to hear from you so that I may place the matter before the Trustees.

I remain

Yours Very Sincerely

Hon Treasurer and Secretary

Red Hill

A.S.M Anik Esq London E.C 3

Hyderabad Deccan

I5 December 193I

My dear Mr Anik

I was glad to hear from you after so many weeks. The East End scheme looked on a fair way to success last April and, as intimated to you at the time, a regular Board was formed with $\mathrm{Mr}$ Pickthall as its Secretary to cooperate with your Committee and conduct the proposed Amir Ali Mosque and School at London - when some formalities caused delay and later the second session of the R.T. Conference ${ }^{88}$ intervened to bring the matter to a standstill till now. But the Hyderabad Delegation is at last expected back at the end of this month and I presume their final decision with regards to your scheme should soon follow. At any rate it will be possible in a couple of months to inform you of the exact position, I trust; in the meanwhile, you may kindly recommend to your Committee to defer any reconsideration of their last resolution about the scheme till, say the end of February next.

With best wishes for a happy New Year

I remain

Yours Sincerely

\footnotetext{
${ }^{88}$ Second of the three Round Table Conferences that were held in London between I930 and 1932 following the report of the Indian Statutory Commission on constitutional reform, and whose main objective was to move India towards Home Rule. The Nizam was represented by his Prime Minister (Dewan), Akbar Hydari. See Judith M. Brown, Modern India: the origins of an Asian Democracy (New Delhi, 1994).
} 
I January 1932

WLT SYED HASHIMI

REDHILL HYDERABAD-DEGGAN

REGARDING PROPOSED EASTEND MOSQUE RELIGIOUS SCHOOL ANXIOUSLY AWAITING YOUR FINAL REPORT AND DEFINITE ARRANGEMENTS. ANIK

7 January 1932

Syed Hashimi Esq

Red Hill

Hyderabad-Deccan

Dear Syed Hashimi

I thank you for your letter of $I_{5}$ December received on Monday 4 inst. and note that you will shortly know the exact position regarding the proposed Mosque and Religious School in the East End of London and you wish me to keep the matter pending till the end of February.

As we were rather anxious about the matter as it has been pending a long time and there will shortly be a meeting of the Trustees at which a report should be given, I sent you a cable on I January reading:

REGARDING PROPOSED EASTEND MOSQUE RELIGIOUS SCHOOL ANXIOUSLY AWAITING YOUR FINAL REPORT AND DEFINITE ARRANGEMENTS. ANIK

Although you ask in your letter for our Committee to defer any reconsideration till the end of February, I hope you will place my cable before your Committee for consideration as it may help to accelerate the matter.

With kind regards and hoping you are well

I remain

Yours Sincerely

A.S.M Anik 
Syed Hashimi Esq

Red Hill

Hyderabad - Deccan

I March 1932

Dear Syed Hashimi

London Mosque Fund

I sent you a cable on I January this year regarding the proposed Mosque and Religious School in the East End of London and just afterwards I received your letter dated I5 December I93I, which I acknowledge by my letter of the 7 January. From your letter of the 15 December it seemed that you would be able to arrange the matter at the end of last month (February). As I have heard nothing further from you I sent you the following cable yesterday:

\section{HOPE DEFINITE ARRANGEMENTS NOW MADE REGARD- ING PROPOSED EASTEND MOSQUE RELIGIOUS SCHOOL PLEASE REPLY - ANIK}

We shall shortly be having our annual General Meeting and this matter will have to be placed before the Trustees and Members, so I am anxious to know the result. I hope you have been successful in all your efforts and shall be pleased to hear from you.

With kind regards

I remain, dear Syed Hashimi

Yours Sincerely

[A.S.M.Anik]

I3 April I932

Marmaduke Pickthall Esq

Civil Service House

Hyderabad - Deccan

Dear Mr Pickthall

$\underline{\text { London Mosque Fund }}$

I have received your letter of 3 March, and the same was placed before a meeting of the Trustees which was called on 7 April. They are all greatly disappointed to see the failure of our joint efforts to establish a Prayer House and Religious School in the East End of London.

You know that Nawab Mehdi Yar Jung paid only a flying visit with Dr Sheldrake* to the East End of London. Seeing the interest shown and 
the expressed desire to support this scheme, it is a pity that a person of his position changed his mind and did not place the application before H.E.H the Nizam's Government.

We all know the generosity of His Exalted Highness and the application for this small grant would no doubt have resulted in a liberal endowment to establish Allah's house and the teaching of Islam which would have called forth the gratitude of many poor Moslems.

Syed Hashimi visited every condition in the East End and passed several days in careful investigation of the need of poor Moslems and came to the conclusion that ours was the best scheme. You have lived in London and know the condition of the poor in the East End.

Our funds do not allow us to proceed with such a scheme without substantial help, as whatever is done must be done on a permanent basis.

We warmly appreciate your kind promise to continue your efforts to achieve the object and we hope to hear from you soon that you have been successful. On your Board of Management there are other distinguished gentlemen and if one of them will bring this matter to the notice of His Exalted Highness we are sure that his generous disposition will sanction the desired grant and the scheme will eventually be successful.

With Kind Regards

I remain,

Yours Sincerely

[A.S.M.Anik]

Hon Treasurer and Secretary

London Mosque Fund

I3 April I932

Syed Hashimi Esq

Redhill

Hyderabad-Deccan

Dear Syed Hashimi

London Mosque Fund

I have read with great regret and disappointment your letter regarding the failure of your efforts, on account of Nawab Mehdi 
Yar Jung's refusal to place the application before H.E.H the Nizam's Government. I note that you will continue your efforts to gain ultimate success and we hope to hear further from you.

I have written to Mr Pickthall as per copy enclosed to which I have very little to add.

With very kind regards

I remain, dear Syed Hashimi

Yours Sincerely

[A.S.M.Anik]

Villa Jane Andree Le Cap D'Antibes

is April I932

\section{Dr Mr Anik}

Thank you for your letter of 24 March which I would have answered sooner, but I have been to the Disarmament Conference at Geneva, where I represent India,$^{89}$ and it is only now, during a short holiday, that I am able to deal with my own personal affairs.

I am sorry to hear that you have not been well, and I do hope that now that the winter is over you will soon get better.

It is indeed disappointing to hear that the scheme for a Prayer House and Religious School in the East End of London has not materialised and very discouraging for those who have worked so hard. I regret that I was unable to be present at the meeting on April 7 but I see little likelihood of being in London this year as the Disarmament Conference may continue until mid-summer. I strongly approve of the nomination of Dr Sheldrake to the Committee of the London Mosque Fund. He is a devoted worker and has the welfare of Islam at heart. I am very sorry to hear of the death of Ali Abdulla Bay.

With all good wishes, and I hope most sincerely that you will soon be quite well again.

Yours very truly

Aga Khan

\footnotetext{
${ }^{89}$ The Aga Khan represented India at the Geneva Disarmament Conference in 1932.
} 


\section{A meeting of the Trustees was held on Thursday 7 April I932 at the Waldorf Hotel, Aldwych, London W.C. 2 at 3 pm}

\section{Present:}

The Rt Hon Lord Lamington (Chairman)

The Rt Hon Lord Ampthill

Col Nawab Malik Sir Umar Hayat Khan Tiwana

Mr Waris Ameer Ali

Mr A.S.M Anik (Hon Treasurer and Secretary)

I. The minutes of the last meeting, held on i7 April i93I were read and confirmed.

2. Accounts: The Accounts to 3I December were presented and passed.

3. Auditors: It was proposed by Mr A.S.M Anik and seconded by Lord Ampthill that Messrs. Feasey Hull and Feasey be appointed auditors for the ensuing year. Agreed.

4. Report: A draft report was read by the Hon Secretary and with some slight amendments the same was adopted.

5. A letter from Mr Pickthall regarding the proposed scheme for a mosque and religious school in the East End of London was read. The Trustees regretted that the Committee of Management in Hyderabad had been unsuccessful in their efforts to obtain a grant from the Hyderabad Government, and a suitable reply to Mr Pickthall was drafted.

The scheme was further discussed and the Chairman, the Rt Hon Lord Lamington, offered to write a personal letter to the Financial Secretary to the Hyderabad Government and the offer was very gratefully accepted.

6. Mr Anik proposed that Mr Khalid Sheldrake be elected a member of the London Mosque Fund Committee. The matter was discussed and as $\mathrm{Mr}$ Waris Ameer Ali promised to give every assistance when the necessity should arise, it was decided not to increase the number on the Committee at present. ${ }^{90}$

\footnotetext{
${ }^{90}$ It is not clear why this decision was made.
} 
7. Mr Anil proposed and Sir Umar Hayat Khan seconded a voted of thanks to the Chairman.

The meeting concluded at $3.45 \mathrm{pm}$.

Confirmed: Lamington ig May I933

[These minutes were sent to and approved by Lord Lamington, Lord Ampthill and Mr Waris Ameer Ali.]

Hyderabad-Deccan 22 March 1933

No. 2139

The Rt Hon the Earl of Lamington

3 Wilton Place

London S.W I

Dear Lord Lamington

With reference to your letter dated I4 June 1932 addressed to His Exalted Highness the Nizam recommending financial help to the London Mosque Fund for the education of the poorer classes of Muslims in London, I am commanded by His Exalted Highness the Nizam to say that while fully sympathising with the objects you have in view, he greatly regrets his Government is unable to offer any pecuniary assistance towards the attainment of those objects owing to the present widespread financial depression ${ }^{91}$ and the many demands on our resources within the State itself.

Yours Sincerely

Mahdi Yar Jung

Political Member of H.E.H the Nizam's Government

\footnotetext{
${ }^{91}$ The worldwide Great Depression, which began in the late I920s and continued until the mid-I93os.
} 


\author{
A.S.M Anik Esq \\ Billiter Buildings \\ Billiter Street \\ E.C.3
}

Dear Mr Anik

\title{
London Mosque Fund
}

I am much obliged to you for your letter of i I May enclosing the audited accounts up to the 3 I December 1932 and the draft report.

I am afraid that I shall not be in London on Friday Ig May and it would anyhow not be worth my while to come up for five minutes business. I hope, therefore, that Lord Lamington and the other Trustees will kindly hold me excused.

I suppose you have heard that another scheme for building not only a Mosque but also a Social Club for Moslems is on foot? The movement seems to be organized by a body called "the National League" ${ }^{92}$ which has its office at I6 St James's Street, and the object is that this Club and Mosque should be a Memorial to the late Mary Adelaide Broadhurst ${ }^{93}$ who was, I think, President of the National League. ${ }^{94}$ As the plan is to have a "group of Moslem buildings in St. James's" it seems to me to be beyond the bounds of possibility that the money will ever be collected and I do not think this rival project need worry us although Miss Farquharson, the present President of the National League, tells me that the Moslem Leaders themselves are enthusiastic about the project.

I think you would do well just to mention this matter at the meetings of the British Red Crescent Society and the London Mosque Fund.

Yours Sincerely

Ampthill

\footnotetext{
${ }^{92}$ See Introduction, p. I5, n. 62.

${ }^{93} \mathrm{BL}, \mathrm{IOR}, \mathrm{P} \& \mathrm{~J}(\mathrm{~S}) / 916$, I934, fo. 243 , Lord Willingdon to Sir Samuel Hoare, 20 June I933.

${ }^{94}$ See Introduction, p. I5, n. 62.
} 
Present:

The Rt Hon Lord Lamington (Chairman)

Col Nawab Malik Sir Umar Hayat Khan, Tiwana

Mr Waris Ameer Ali

Mr A.S.M Anik (Hon Treasurer and Secretary)

I. The Minutes of the last meeting held on 7 April I932 were read, confirmed and signed.

2. The Accounts: The accounts to 3i December 1932 were presented and proposed by Sir Umar Hayat Khan, seconded by $\mathrm{Mr}$ Waris Ameer Ali and unanimously passed.

3. Report: A draft report was read and unanimously adopted. Agreed.

4. The Treasurer-[illegible] It was resolved that the Treasurer is authorised that whenever there is surplus money not required for immediate need to be invested in Trustees Securities. Agreed.

5. Auditors: It was proposed by Mr A.S.M Anik and seconded by Mr Waris Ameer Ali that Messrs. Feasey Hull and Feasey be appointed auditors for the ensuing year. Agreed.

6. A communication from Hyderabad stating that no contribution will be made by the Hyderabad Government for the Prayer House and School in the East End.

7. A letter from Lord Ampthill was read by the Chairman regarding Miss Farquharson's scheme. The Trustees did not consider to associate with the National League. Decided to lay the letters on the table..$^{95}$

8. It was proposed by Sir Umar Hayat Khan and seconded by Mr Waris Ameer Ali that efforts were to be made to secure a Moslem Preacher and Prayer Room in the East End of London.

9. A vote of thanks to the Chairman and to Mrs Ameer was unanimously passed.

Confirmed: Lamington

\footnotetext{
${ }^{95} \mathrm{Handwritten}$, after the previous words were crossed out.
} 


\section{The Annual General Meeting was held on Tuesday 2 April I935 at the Waldorf Hotel, Aldwych, London $W_{2}$}

There were present:

The Rt Hon Lord Lamington, G.C.M G, G. C.I. E, Chairman Trustee The Rt Hon Lord Ampthill, G.C.I.E, G.C. S. I, Trustee

Mr Waris Ameer Ali, trustee

Gholam Ali Khan Ardalan, ist Secretary to Iranian Legation Mr A.S.M Anik, Treasurer and Secretary

I. The Minutes. The Minutes of the last meeting held on ig May I933 were read, confirmed and signed.

2. The Accounts. The accounts to 3I December I93I were presented and passed.

3. Report. A draft report was read and unanimously adopted.

4. Auditors. Messrs. Feasey Hull and Feasey were re-appointed auditors for the ensuring year. Unanimously agreed.

5. Resignation of Sir Umar Hayat Khan as one of the Trustees and a member has been noted with regret.

6. Resolved to invite Sir Abdul Qadir* as a Trustee of the Board.

7. It was proposed by the Rt Hon Lord Ampthill and seconded by Waris Ameer Ali that an expenditure not exceeding EI5O shall be incurred from the income of the trust for the purpose of Moslem public worship by congregations in the East End of London. Unanimously agreed.

8. It was proposed by Mr A.S.M Anik and seconded by Mr Ameer Ali that a contribution not exceeding $\mathcal{E}_{\mathrm{I}}$ Io be paid for Ashura Celebration $^{96}$ on Sunday ${ }_{4} 4$ April in the East End of London on the understanding that all Moslems participate. ${ }^{97}$ This was unanimously agreed.

\footnotetext{
${ }^{96}$ Ashura is the tenth day of the Muslim month of Muharram. It is the day when the death of Hussain, son of the Caliph Ali (the Prophet Muhammad's son-in-law) is commemorated, in particular by Shias.

${ }^{97} \mathrm{I}$ This inclusive approach to Ashura is significant, as the East London Mosque today is a Sunni Muslim place of worship.
} 
9. It was suggested by Mr Ameer Ali that the opinion of the brokers to be taken to change investment from India $3 / 2 \%$ to any fixed trustee security.

Io. A vote of thanks to the Chairman was unanimously agreed.

Confirmed: Lamington i3 May 1936

The auditors having pointed out that the depreciation written off the cost of the India $3 \% \frac{1}{2} \%$ stock in 193 I amounting to $\mathcal{E}_{\mathrm{I}} \mathrm{r} 895-9-3 \mathrm{had}$ been more than recovered by the increase in the market value since that date, it was resolved that such depreciation be now written back on 3I December i935.

Lamington - Trustee and Chairman

Ameer Ali - Trustee

A.S.M Anik - Treasurer

\section{The Annual General Meeting was held on Wednesday} 13 May 1936 at the Waldorf Hotel, Aldwych, London WC2. The Rt Hon Lord Lamington G.C.M G, G. C.A.E presided.

Present:

Lord Lamington Chairman

The Rt Hon Sir Frederick Hugh Sykes* Khan Bahadur Shaikh Sir Abdul Qadir Mr Waris Ameer Ali

Mr A.S.M Anik

Monsieur Ardalan the First Secretary of Imperial Iranian Legation

The Minutes The Minutes of the last meeting held on 2 April 1935 were read, confirmed and signed. The Chairman said:

"It is with the deepest regret that we record the death of the Rt Hon Lord Ampthill G.C.I.E, G. C. S.I, who died on 7 July I935. He was one of the Trustees of the Fund from the commencement in IgIo and gave very valuable assistance and advice."

The Hon Treasurer informed the Committee that a letter of condolence had been sent by him on behalf of the Committee to 
Lady Ampthill and was acknowledged by her. This was approved by the Committee.

It was unanimously resolved that Major Gen The Rt Hon Sir Frederick Hugh Sykes, P.C, G.C.S.I, and Khan Bahadur Shaikh Sir Abdul Qadir, member of the Council of the Secretary of State for India be appointed Trustees in the vacancies caused by the death of the Rt Hon Lord Ampthill and by the resignation of Major Gen Sir Umar Hayat Khan who had left for India. This was agreed to and they joined the meeting.

In view of the appointment of the Rt Hon Sir Frederick Hugh Sykes and Khan Bahadur Shaikh Sir Abdul Qadir as Trustees the resolution of 9 January was to be amended as follows:

Viz. that all cheques and instructions to be signed by any one of the following

The Rt Hon Lord Lamington

Mr Waris Ameer Ali

Major General Rt Hon Sir Frederick Hugh Sykes

Khan Bahadur Shaikh Sir Abdul Qadir

being Trustees of the London Mosque Fund and countersigned by the Hon Treasurer Mr A.S.M Anik.

Copy of the above resolution certified by the Chairman Lord Lamington and signed by Mr Waris Ameer Ali and Mr A.S.M Anik to be sent to the bankers The Bank of England.

Specimen signature cards were signed by Sir Frederick Sykes and Sir Abdul Qadir to be sent to the bankers The Bank of England.

The Accounts The audited accounts to 3I December 1935 were presented and passed.

Auditors It was proposed by Sir Abdul Qadir and seconded by Monsieur Abdalarn that Messrs Feasey Hull and Feasey be reappointed auditors for the ensuing year. This was unanimously agreed.

Report A draft report for the year 1935 was read and unanimously adopted to get same printed and circulated. 
It was unanimously agreed that a sum of $£$ io be paid to Jamait-ulMuslimin $[\mathrm{sic}]^{98}$ for Moulud ${ }^{99}$ and a further $£ 5$ as per letters of 26 May I936.

Sir Abdul Qadir was requested to draft a letter to be sent to H.E.H the Nizam on the occasion of his Jubilee for a contribution towards a Mosque in the East End of London and to the employment of a permanent Moulvi to conduct prayers for Moslems in that part of London.

Appointment of a Secretary This matter has been kept in abeyance for further consideration.

\begin{abstract}
A vote of thanks to the Chairman was proposed by Sir Abdul Qadir and seconded by Monsieur Ardalan and heartily passed.
\end{abstract}

Confirmed: Lamington 26 Feb 1937

\footnotetext{
${ }^{98}$ The Jamiat-ul-Muslimin (Muslim Association) was established as a charitable society in 1934 with an office in Canton Street in East London. Branches were soon opened in Birmingham, Manchester, Glasgow, and Newcastle. 'The first meeting was held in 222 High St Poplar E.I4 on $29^{\text {th }}$ March 1934 [... when] a provisional committee was formed', with I.I. Kazi* as President, Sheikh Rahim Bukhsh as Vice-President, Said Amir as Secretary, and Noor Mohamad Sangha as Treasurer. See ELM Archives, Jamiat-ulMuslimin (Muslim Association), Register Karrawai. Its objectives included the creation of facilities for the observance of Islam, providing help to poor and needy Muslims, promoting 'social intercourse between resident Muslims and visitors' to Britain, and working 'for the moral, intellectual and economic advancement of Muslims throughout the world'. In its First Annual Report, 1934-1935 (ELM Archives), detailing its activities up to 28 February 1935, it noted the Association's efforts 'to bring about co-operation between the Nizamia Mosque and Amir Ali Mosque Trusts to construct a Mosque in a central place in London'. It urged the Nizamia Mosque Trust to dispose of its site near Kensington, since this location was 'far off from the Muslim population in London', and instead to build a mosque 'in the East End of London, the centre of Muslim population and the resort of seamen from abroad'. It established its office at 30 Church Lane, Commercial Road, London, Er. Between 1934 and I938, its main activities consisted of organizing Friday congregations and the celebration of Muslim festivals in the East End of London. These events were held in rented premises, and the congregations were largely local, although distinguished guests were invited from other parts of London too. From I938, the Jamiat became politically more vocal, and for the next few decades it actively represented sizeable sections of the East End's Muslim population: see BL, IOR, L/P\&J/I2/468, fos 7I-74. For details of its protest against the writings of H.G. Wells, see the Introduction, pp. I9-2I.

${ }^{99}$ Celebration of the birth of the Prophet Muhammad, also known as Milad-i-Nabi.
} 


\section{The Annual General Meeting of the London Mosque Fund was held on Friday 26 February 1937 at the Waldorf Hotel, Aldwych, London WG2. The Rt Hon Lord Lamington G.G.M.G, G.G.I.E Ghairman presided. There were present:}

The Rt Hon Lord Lamington G.C.M.G, G.C.I.E

Maj Gen The Rt Hon Sir Frederick Hugh Sykes P.G., G.C.S.I, G.C.I.E, G.B.E, K.C.B, C.M G.

Khan Bahadur Shaikh Sir Abdul Qadir

Mr Waris Ameer Ali

Mr A.S.M. Anik

The Minutes. The minutes of the last meeting held on I3 May 1936 were read, confirmed and signed.

Accounts. The audited accounts up to the 3i December 1936 were presented and passed. The resolution was proposed by Sir Abdul Qadir and seconded by Mr Waris Ameer Ali and carried unanimously.

Auditors. It was proposed by Sir Abdul Qadir and seconded by $\mathrm{Mr}$ Waris Ameer Ali that Messrs. Feasey Hull and Feasey were to be re-appointed auditors for the ensuring year. This was unanimously agreed.

Loan. It was agreed that a loan of $£ 5^{\circ}$ to Indigent Moslems Burial Fund be made from the balance at the Bank of England. Unanimously agreed.

Report. The report of the work of the Fund up to the 3I December I936 was read and adopted. This was proposed by Sir Abdul Qadir and seconded by Mr Waris Ameer Ali.

The appointment of Sir Firozkhan Noon, ${ }^{* 100}$ the High Commissioner for India as a Trustee of the Fund was unanimously agreed to, subject to his concurrence.

Transfer of Securities. $£ 7,400$ India $3 \frac{1}{2} \%$ I93 I and $£ 3,150$ War Loan I952 was made in the names of the following Trustees:

The Rt Hon Lord Lamington

The Rt Hon Sir Frederick Hugh Sykes, P.C

Khan Bahadur Shaikh Sir Abdul Qadir

Mr Waris Ameer Ali

${ }^{100}$ Malik Sir Firoz Khan Noon. 
All the papers regarding this transfer and to inscribe as Book Stock in the Stock Books of Bank of England were signed by the above transferees and witnessed.

H.E.H The Nizam's Silver Jubilee. It was reported by Mr Anik that a cable was sent to H.E.H the Nizam of Hyderabad and Benar congratulating him on his Silver Jubilee and in reply a cable was received from His Exalted Highness reading "Thanks, greatly appreciate contents of your telegram. Nizam"

Vote of thanks to the Chairman was carried unanimously.

Sir Firozkhan Noon subsequently agreed to become a Trustee of the Fund. This has been duly notified to all the other Trustees, and the Bankers, the Bank of England sending his specimen signature for signing cheques and instructions.

Confirmed: Lamington i7 May 1938

\section{The Annual General Meeting of the London Mosque Fund was held on Tuesday 17 May 1938 at India House, Aldwych, London WG2. ${ }^{101}$ The Rt Hon Lord Lamington G.C.M.G, G.C.I.E Ghairman presided. There were present:}

The Rt Hon Lord Lamington G.C.M.G, G.C.I.E

Khan Bahadur Shaikh Sir Abdul Qadir

Mr Waris Ameer Ali

Sir Firozkhan Noon

Mr Arthur Bird* (on behalf of the Treasurer, Mr A.S. M. Anik)

A message of regret for absent was received from Sir F Hugh Sykes and Mr A.S.M. Anik

The Minutes. The minutes of the last meeting held on 26 February I937 were read, confirmed and signed.

Accounts. The audited accounts up to 3I December were presented and passed. The resolution was proposed by Sir Abdul Qadir and seconded by Mr Waris Ameer Ali and carried unanimously.

\footnotetext{
${ }^{101}$ This meeting of the LMF was held at the Office of the High Commissioner for India, as were several of its subsequent meetings.
} 
Loan. Mr Bird reported that the loan of $£ 5^{\circ}$ made to the Indigent Moslems Burial Fund was being repaid.

East End Prayer House. There was a long discussion regarding the building of a prayer house in the East End of London and it was agreed that the matter should be left to Sir Firoz Khan to make enquiries through his marine superintendent and make a report at a later date.

Sir Abdul Qadir raised the matter regarding the payment of an honorarium to $\mathrm{Mr} \mathrm{H}$. Izharul Hasan who was at present leading the Friday prayers in the East End of London. ${ }^{102}$

Sir Abdul Qadir said he had asked Mr Hasan to come along in case the other Trustees wished to interview him. This was agreed to. Mr Hasan was then called in and several questions were put to him regarding his qualifications.

It was proposed by Sir Abdul Qadir and seconded by Mr Waris Ameer Ali that an Honorarium of $\mathcal{E}_{\mathrm{I}}$ per week be paid to Mr Hasan for leading Friday prayers etc in the East End of London.

One month's notice to be given by either side to terminate the arrangement. This was agreed to.

Hon Secretary. Lord Lamington said he had approached Ernest

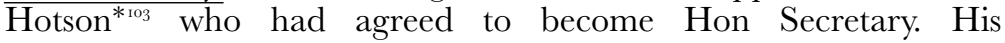
appointment was unanimously agreed to.

Assistant Hon Secretary. Sir Abdul Qadir proposed that Mr Arthur Bird be appointed assistant Hon Secretary and that he be paid an honorarium of $\mathcal{E}$ Io per annum. Seconded by Mr Waris Ameer Ali. His appointment unanimously agreed to, also the proposed honorarium.

Auditors. Proposed by Mr Waris Ameer Ali and seconded by Sir Abdul Qadir that Messrs Feasey Hull and Feasey be re-appointed auditors for the ensuing year. This was unanimously agreed to.

Proposed by Mr Waris Ameer Ali and seconded by Sir Abdul Qadir a vote of thanks to Sir Firoz Khan Noon for his kindness in allowing the

\footnotetext{
${ }^{102}$ Friday prayers were being organized by the Jamiat-ul-Muslimin, first in the Queen's Hall and then at the King's Hall on Commercial Road. Various other Muslim festivals were also regularly held there. The LMF provided some financial assistance. As we have already seen, the need for more permanent premises had been under discussion for some years. See also ELM Archives, Jamiat-ul-Muslimin papers.

${ }^{103}$ Sir John Ernest Buttery Hotson.
} 
Trustees the use of his room for the meeting. Carried unanimously. A vote of thanks to the Chairman was carried unanimously.

Confirmed: Lamington 9 December 1938

\section{A Meeting of the Trustees of London Mosque was held on Friday 9 December 1938 at 3 Wilton Place London SW. The Ghairman the Rt Hon Lord Lamington G.C.M.G, G.C.I.E, Ghairman presided. There were present:}

The Rt Hon Lord Lamington G.G.M.G, G.G.I.E

Khan Bahadur Shaikh Sir Abdul Qadir

Mr Waris Ameer Ali

Sir Firoz Khan Noon

Sir Ernest Hotson (Hon Secretary)

Mr Arthur Bird (Assistant Hon Secretary)

A message of regret for absence was received from Sir Frederick $\mathrm{H}$. Sykes

The Minutes of the last meeting held on i7 May 1938 were read, confirmed and signed by the Chairman.

Business remaining from the Minutes: Nil.

Purchase of a site for a Mosque. Sir Firoz Khan Noon reported that he and Sir Abdul Qadir had seen two possible sites both of which are now in the market. One, in Adler Street, leading out of Commercial Road, is not built on, so that building would have to be undertaken immediately. Further it is quite close to a Jewish place of worship. The other nos. 446 and 448 Commercial Road, has building which with some alteration would be suitable. The corner site No. 450 is also to let, but not for sale. The price asked for 446 and 448 is about $\mathcal{f}^{2,000 \text {. }}$ Some of the rooms could be converted into bedrooms for the use of sailors and other Moslems visiting London.

Some could be let out as shops. No $45^{\circ}$ could also be used, if it were decided to take a lease of it. The purchase of No 446 and 448 was approved in principle and a sub Committee consisting of Sir Abdul Qadir, Mr Waris Ameer Ali and Sir Ernest Hotson was appointed to inspect the site and go fully into all details, and make estimates of expenditure, and if possible to secure an option on the site, and to report to the Committee as soon as possible. 
Sir Ernest Hotson as Hon Secretary was asked to convene a meeting or meetings of the sub Committee. Sir Firoz Khan promised to send a surveyor to examine the site.

The Hon Sec was instructed to inform the Jamiat-ul-Muslimin in reply to its letter dated 25 November 1938 that the purchase of a site for a mosque is under consideration.

There was no other business. A vote of thanks to Lord Lamington for his hospitality and for providing was unanimously passed.

Confirmed: Lamington io March 1939

\section{Minutes of the Meeting of the London Mosque Trustees at 3 Wilton Place at I I am on Friday Io March I939. Lord Lamington took the chair. There were present:}

Rt Hon Lord Lamington

Sir Abdul Qadir

Sir Frederick Sykes

Sir Firoz Khan Noon

Mr Waris Ameer Ali

Sir Edward Hotson (Hon Secretary)

Mr A. Bird (Assistant Hon Secretary)

Minutes. The minutes of the last meeting held on 9 December 1938 were read and approved and signed by the Chairman.

Business arising. The action taken by the sub-committee appointed at the last meeting to enquire further into the suitability of the site in the Commercial Road proposed for the Mosque was reported to the Trustees.

It was decided that the Adler Street site was to be preferred and the same sub-committee (Sir Abdul Qadir, Mr Waris Ameer Ali and Sir Ernest Hotson) was empowered to proceed with negotiation regarding its purchase. Sir Firoz Khan Noon having kindly agreed to interview the surveyor Messrs Cuthbert Lake \& Sutton, ${ }^{104}$ the Hon Secretary was instructed to write to Sir Firoz Khan Noon stating the points to be considered at the interview, in the first place the charge to be made by the surveyors for work already done and to be done in future,

\footnotetext{
${ }^{104} \mathrm{~A}$ London firm of surveyors, estate agents, and auctioneers, originally founded in $\mathrm{I} 76 \mathrm{r}$ : see http://www.cuthbertlake.co.uk/ (accessed ıo January 20I0).
} 
and if these points are satisfactorily settled, the conditional offer to be made to the vendors of the Adler Street site, the offer not to exceed $£ 3$, ooo, and to depend on the arrangements of suitable conditions regarding the area to be covered by buildings and other matters with the [illegible].

Sir Firoz Khan Noon also kindly agreed to take up the question of these conditions with the L.C.C. ${ }^{105}$

The Trustees notice that the sum available for the construction and maintenance of the Mosque is, at present market rate for the securities, much less than $\mathcal{E}_{\mathrm{ro}}$,ooo.

They were of the opinion that a further sum of two lakhs of rupees ${ }^{106}$ at least would be required and that an appeal to the public in this country and in India would have better chance of success after the purchase of the site.

They therefore postponed the drafting of an appeal, but welcome the proposal of individual Trustees to canvas their friends for support at once.

There being no other business the meeting closed with a vote of thanks to the Chairman for presiding and for his hospitality.

Confirmed: Lamington 8 June I939

[The following notes were typed up and attached to the minutes on a separate sheet]

The Trustees notice that the sum available for the construction and maintenance of the Mosque is, at present market rate for the securities, much less than $£$ io,ooo.

They were of the opinion that a further sum of two lakhs of rupees at least would be required and that an appeal to the public in this country and in India would have better chance of success after the purchase of the site.

\footnotetext{
${ }^{105}$ London County Council.

${ }^{106}$ In the late I930s, a pound Sterling was worth approximately 9.0o Indian Rupees (Rs.). Hence, two lakhs of rupees equalled approximately $\mathcal{E}^{25}, 000$ at this time.
} 


\section{A Meeting of the Trustees of The London Mosque Fund held on Thursday 8 June 1939 at India House. The Ghairman, the Rt Hon Lord Lamington G.C.M.G, G.C.I.E presided. There were present:}

Rt Hon Lord Lamington

Sir Abdul Qadir

Sir Frederick Sykes

Mr Waris Ameer Ali

Sir Edward Hotson (Hon Secretary)

Mr A. Bird (Assistant Hon Secretary)

Minutes. The minutes of the last meeting held on I7 May I939 were confirmed and signed by the Chairman.

Business arising. None

Accounts. On the proposal of Sir Abdul Qadir, seconded by Sir F. Sykes the accounts for the year 1938 were approved and passed.

Auditors. On the proposal of Mr Waris Ameer Ali seconded by Sir Abdul Qadir the Auditors Messrs Feasey Hull and Feasey were reappointed for the current year.

Mosque Site. Sir Abdul Qadir reported the action taken by the subcommittee regarding the purchase of a site for the Mosque. An offer was put in for the Adler Street site, but an earlier offer was under the consideration of the vendors, and the site has since been sold. It is understood that the price paid is substantially more than $£ 3$, ooo, the limit fixed by the Trustees.

A third site, in Back Church Lane was inspected by Sir Abdul Qadir and Sir Ernest Hotson, but as its price was expected to be over $£ 5,000$ it had to be dismissed from consideration. Although in some respects suitable, it seemed likely to be very noisy.

There remained therefore only the site in Commercial Road. Nos. 446, $44^{8}$ and 450. All three houses are now available for purchase though vacant possession could only be obtained of one of them at once. The site has again been inspected by Messrs Cuthbert Lake and Sutton, whose report dated 2 June was read to the Trustees.

At the proposal of Sir Abdul Qadir seconded by Sir Frederick Sykes, the same sub-committee namely Sir Abdul Qadir, Mr Waris Ameer Ali 
and Sir Ernest Hotson was re-appointed to proceed with negotiation for the purchase of this site. They were empowered to make a conditional offer up to $£ 3,000$, beginning with $£ 2,500$, as suggested by Messrs Cuthbert Lake and Sutton, or $£ 2,75^{\circ}$ as might seem best to them, the price demanded by the vendors viz. $£ 3,250$.

The offer was to be subject to satisfactory information about the sites on which vacant possession of the two occupied houses could be named, and a further report by Messrs Cuthbert Lake and Sutton as to suitability of the site for the Trustees' purposes and the probable cost of demolition of buildings, and to the consent of the London County Council to the erection of a Mosque on the site, and such other matters as might seem proper to the sub-committee.

It was decided that when Sir Abdul Qadir returns to India his successor as Trustee Sir Hassan Suhrawardy* should, if willing, take his place on the sub-committee.

It was agreed that the account of Messrs Cuthbert Lake and Sutton for $\mathcal{E}^{2}$ I for work already done should be paid.

A letter received by the Hon Secretary purporting to come from the Jamiat-ul-Muslimin was read. As it is unsigned, and only has typed signature "Jamiat-ul-Muslimin" it was decided to take no notice of it. ${ }^{107}$

A letter received by the Hon Secretary from Mr J.H. Mougy ${ }^{108}$ was read. Mr Mougy asked for help to pay an account received from the City Hotel for the expense of a Tea Party to celebrate the Anniversary of the Birthday of the Prophet, Sir Abdul Qadir mentioned that help had from time to time been given to the Moslems of the East End towards the cost of parties on similar occasions but it was considered that the two cases were not parallel. The Hon Secretary was instructed to inform Mr Mougy that the Trustees regretted that they had no funds available for such functions.

\footnotetext{
${ }^{107}$ It is not clear why this letter was ignored. It has not been found so the contents are unknown.

${ }^{108}$ Ibrahim Mougy was 'an Egyptian Moslem' (see BL, IOR, P\&J (S)/607/33, fo. 207). In 1938 , having been resident in Britain for several years, he was hoping to become a naturalized British subject; he married Mary Straker-Wilson on I7 August 1939 (see The Times, I9 August I939). Considered 'well-disposed and honest' by the Foreign Office (BL, IOR, L/P\&J/I2/468, fo. 213, letter dated 3 February I938), he was engaged 'in translating the Authentic Traditions of Mahomet into English on behalf of the Al Hazar University of Cairo'. He was reported in The Times as the 'organizer of the Islamic Institute of London' and said to be collecting funds in $193^{8}$. The 'first public function in the form of Id prayers was held in February 1938 at the Essex Hall at which [ . . ] the prince [Seif-ul-Islam Hussein,
} 
Business. Regret was expressed on the impending return to India of Sir Abdul Qadir who has rendered such valuable assistance to the Fund during his stay in London.

According to the Trust Deed his place as Trustee will be taken by his successor as advisor to the Secretary of State for India, to which post Sir Hassan Suhrawardy has been appointed. The Hon Secretary was instructed to make the necessary arrangements for the transfer of securities in consultation with the Hon Treasurer.

It was agreed that the Bank of England be notified of the change and a fresh authority for the signing of cheques supplied to them.

The proceedings then terminated with a vote of thanks to the Chairman.

The Hon Secretary was also instructed to thank the High Commissioner for the loan of the room in which the Trustees met.

Confirmed: Lamington 8 December 1939

\section{Meeting of the Trustees of The London Mosque Fund was held, at the kind invitation of Lord Lamington, at 3 Wilton Place on Friday 8 December 1939 at Io.30 a.m}

There were present:

Lord Lamington

Sir Hassan Suhrawardy

Sir Frederick Sykes

to whom Mougy was acting as secretary] of Yemen was present' (ibid., fo. 208). At an Eid-ulAzha celebration at the Royal Egyptian Club, he spoke of the need for a Muslim centre in London, which his committee was seeking to provide (The Times, 3I January I939). Dr Mougy, who was apparently studying at the University of London in 1937 (see his letter to The Times, I4 July I937), corresponded with the Foreign Office regarding the proposed establishment of an Islamic Centre in London in I938. He hoped that the British government would support his scheme, by, among other steps, putting at his disposal some suitable premises (BL, IOR, $\mathrm{L} / \mathrm{P} \& \mathrm{~J} / \mathrm{I} 2 / 468$, fos 2I6-2I9). However, the Foreign Office 'were not convinced that Mougy was the right person to run it', as he was thought to want to establish it in opposition to the Mosque in Woking, which - in Mougy's view - was controlled by the heterodox Ahmadi sect, but which, according to official reports, 'most Mohammedans have come to regard as a Sunni Mosque'. He was referred to the India Office (see BL, IOR, P\&J (S)/5I3, I938, fo. 203 , letter dated i6 June I938). 
Mr Waris Ameer Ali

Sir Edward Hotson (Secretary)

Mr A. Bird (Assistant Secretary)

An apology for his absence was received from Sir Firoz-Khan Noon.

The Minutes of the previous meeting, held on 8 July $1939^{\text {109 }}$ were read and confirmed.

On the proposal of Sir Frederick Sykes, seconded by Mr Waris Ameer Ali, Sir Hassan Suhrawardy was appointed as Treasurer.

It was resolved that, owing to the resignation of Sir Abdul Qadir, on account of the expiration of his term of office as Advisor to the Secretary of State for India, his successor, Sir Hassan Suhrawardy, be appointed Trustee in his place, and be authorised to sign cheques and instructions of the London Mosque Fund, and he is hereby appointed and authorised. This resolution shall be signed by the Chairman and sent to the Bankers to take note.

It was further resolved that cheques shall be signed by the Hon Treasurer, Sir Hassan Suhrawardy, and any one of the Trustees (viz. Lord Lamington, H H Aga Khan, Sir Frederick Sykes, Sir Firozkhan Noon, Mr Waris Ameer Ali).

The Trustees expressed their deep regret at the death of Mr A S M Anik, who had served the Fund as Hon Treasurer for many years, and whose absolute honesty of purpose and undeviating efforts to do the best for everybody commanded their warm admiration, and resolved that a letter of condolence be sent to the members of his family. This resolution was passed by the Trustees standing in solemn silence.

The Sub-Committee, consisting of Sir Hassan Suhrawardy, Mr Waris Ameer Ali and Sir Ernest Hotson, was given renewed authority to proceed with arrangements for the purchase of the Commercial Road site, the limit of price being fixed at $\mathcal{f}_{3}$,ooo as before. Sir Hassan Suhrawardy explained the action which had been taken since the last meeting, and showed the correspondence between himself and Messrs Cuthbert, Lake \& Sutton and the plans prepared by them.

The Trustees expressed their appreciation of the work done for them by Mr A Bird, and learned with much regret that, owing to the probable closing down of the late Mr Anik's business in the near future, Mr Bird's connection with the Fund would be brought to an

\footnotetext{
${ }^{109}$ This appears to be a mistake as, according to the minutes of the meeting itself, the meeting had taken place on 8 June 1939 .
} 
end. They would be glad to make use of Mr Bird's services as long as they might still be available. Sir Hassan Suhrawardy undertook that either he or Sir Firozkhan Noon would take charge of the records when Mr Anik's office was closed and arrange for carrying on the work now done by Mr Bird, until permanent arrangements for both could be made.

The meeting closed with a vote of thanks to the Chairman.

Lamington ig February I940

\section{A meeting of the Trustees of the London Mosque Fund was held at 3 Wilton Place at 10.30 am on 19 February 1940. There were present:}

The Rt Hon Lord Lamington (in the Chair)

Major-General the Rt Hon Sir Frederick Sykes

Sir Hassan Suhrawardy

Mr Waris Ameer Ali (also representing Sir Firozkhan Noon)

Sir Ernest Hotson was absent for reasons of health

I. The Minutes of the last meeting were read, approved and signed by the Chairman.

2. The progress of the work of the Sub-Committee for the purchase of a site was reported by Sir Hassan Shurawardy. After discussion it was proposed by Sir Frederick Sykes and seconded by Mr Waris Ameer Ali that steps should be taken by Sir Hassan Suhrawardy to purchase the Commercial Road site for a maximum of $£_{3}$, ooo through Messrs Cuthbert, Lake \& Sutton, subject to reports by a firm of solicitors approved by the Trustees, that the site is free of encumbrances, etc.

3. Mr Waris Ameer Ali, on his own behalf and on behalf of Sir Firozkhan Noon, commended the work done and the initiative taken by Sir Hassan Suhrawardy in forwarding the project of building a Mosque in the East End, but they thought that with regard to Sir Hassan's resolution, which formed item No 3 of the agenda of the meeting, they considered it advisable to go forward with great caution, and to find out whether a Committee or a Board of Trust were going to be appointed to administer the funds of the Scheme of His Excellency 
the Egyptian Ambassador, ${ }^{110}$ also to find out what funds there were. A discussion followed.

It was resolved that the project for amalgamating the assets of the fund with those of the Scheme of His Excellency the Egyptian Ambassador be deferred for further consideration, and that the Trustees should enquire from $\mathrm{H} \mathrm{E}$ the Egyptian Ambassador what are his suggestions in regard to this matter.

4. The question of the appointment of Mr Charles Gordon Ross, M.C as Honorary Treasurer of the Fund was considered. Sir Frederick Sykes stated that the Trustees did not know Mr Ross, and suggested that the proposal of his appointment should be deferred for further investigation. Sir Hassan Suhrawardy pointed out that the name of Mr Ross was suggested to him by Sir Firozkhan Noon, and the firm of solicitors of which he was the senior partner was recommended to the High Commissioner by the Chief Justice of the Punjab, and this matter had been discussed and approved at a meeting of the Sub-Committee held on i8 January. The matter was deferred for consideration at a full meeting of the Trustees.

5. The question of the appointment of a firm of solicitors to act for the Society was raised, and Sir Hassan Suhrawardy said that the firm of Messrs. Cardew-Smith \& Ross appeared to be suitable for this work. Sir Frederick Sykes suggested that the opinion of the solicitors to the High Commissioner should be taken, but Sir Hassan Suhrawardy said that as the firm of Messrs Cardew-Smith \& Ross had been recommended to the High Commissioner by the Chief Justice

${ }^{110}$ In June 1939, the Egyptian Ambassador met the Conservative politician Lord Lloyd (I879-I94I), and discussed with him a proposal for the erection of a mosque in central London. The Egyptians would take the chief share in arranging for its construction and staff, including arranging for teachers of the students to be housed in adjacent hostels. At that point he wished only to secure from the British government a general blessing for the idea, and was hopeful that sufficient funds could be raised from Islamic sources. In February I940, at a dinner of the Royal Central Asian Society, the Ambassador announced that he had submitted proposals to King Farouk, who had accepted them and had agreed to give the project his patronage; he said that he would ask 'representatives of various Moslem nationalities to meet [...] for the purpose of drawing up a satisfactory scheme'. Lord Zetland, the Secretary of State for India, and Suhrawardy were also present - the former's approval and sympathy was enlisted (see extract from his private letter to Lord Linlithgow, dated 4/9 February I940, IOR, BL, P\&J (S)/7I3, I940, fo. I23), and the latter said that he would be glad to assist in co-ordinating the various efforts being made in this regard. See The Times, I February 1940. Lloyd felt that the assets and funds of the LMF and the Nizamiah Mosque Trust could be merged with those of the Central London Mosque Trust and applied to the purchase and construction of a mosque on a suitable site. He asked for assistance from the government to donate the land. See BL, IOR, P\&J (S)/7I3, I940, fo. II5, George Lloyd to Marquess Linlithgow, Viceoroy in India, 8 February I940. 
of the Punjab, and all legal work is controlled by the Legal Advisers at the India Office, their opinion, if any, ought to be consulted.

It was resolved that the opinion of legal advisers at the India Office be taken in this matter.

The meeting closed with a vote of thanks to the Chair.

Confirmed: F Sykes 6 January I94I

\section{Resolution}

Resolved that His Excellency Dr Hassan Nachat Pasha, ${ }^{*}$ the Egyptian Ambassador, be requested to include in his scheme of building a central Mosque in London, the scheme of building a Mosque in the East End on the following condition:

I) That the cash, investments in Government securities or otherwise and immovable property standing to the credit of the London Mosque Fund Trust, and representing the total assets thereof, be amalgamated with the London Mosque Fund started by His Excellency Dr Hassan Nachat Pasha, the Egyptian Ambassador, and controlled by a Committee of management.

2) That in the London Mosque in the East End a tablet should be placed mentioning the total assets which have been transferred from the London Mosque Trust Fund. In this tablet should also appear the name of the late Rt Hon Syed Ameer Ali, the Life-Chairman and originator of the scheme, together with the names of the present Trustees, the Rt Hon H H the Aga Khan, P.G, G.C.S.I, G.C.I.E, G.C.V.O, LL.D, the Rt Hon Lord Lamington P.R, G.C.M.G, G.C.I.E, Major-Gen the Rt Hon Sir Frederick Sykes, P.C, G.C.I.E, G.B.E, K.C.B, Malik Sir Firozkhan Noon, K.C.I.E, Mr Waris Ameer Ali, I.C.S, (Retd), Al Haj Lt-Gol Sir Hassan Suhrawardy, O.B.E, LL.D, D.Sc, and the Secretary, Sir Ernest Hotson, K.C.S.I.

\footnotetext{
${ }^{\text {"II }}$ Dr Hassan Nachat Pasha (sometimes Pacha) set up a committee of distinguished Muslims in London in I940 to prepare plans for the establishment of a mosque in central London. He became its chairman. Sir Firoz Khan Noon (treasurer), Sir Hassan Suhrawardy, Sheikh Hafiz Wahba, Ata Amin Beg (Iraqi Chargé d'Affaires), and Rauf Chadirji Beg (former Iraqi Minister in London) were appointed its members. Funds up to $\oint_{\mathrm{I}} \mathrm{oo}$, ooo were approved by Parliament for this purpose. See The Times, i4 November i940.
} 
3) That the responsibility for:

a) The maintenance and upkeep of the Mosque

b) The provision of muezzins, ${ }^{\text {II2 }}$ imams and teachers with suitable accommodation for them

should be undertaken by His Excellency the Egyptian Ambassador, and his Committee.

4) This building scheme should include provision of a suitable place where dead bodies may be taken for performing religious rites before they are taken to the London Necropolis Station preparatory to interment at the Muslim burial ground at Brookwood Cemetery. A suitable hearse with appropriate inscription should also be provided.

The above resolution to be proposed by Sir Hassan Suhrawardy and seconded by Sir Firozkhan Noon.

The reasons in support of the above resolution are as follows: ${ }^{113}$

\section{Minutes of a meeting of the Trustees of the London Mosque Fund held at I I am on Friday 24 May 1940 at 3 Wilton Place, SWI by kind invitation of Lord Lamington}

\section{Present:}

Lord Lamington in the Chair

Mr Waris Ameer Ali

Sir Hassan Suhrawardy

Sir Ernest Hotson (Hon Secretary)

An apology for absence was received from Sir Firozkhan Noon

I. The meeting having been convened for a special purpose, the Minutes of the last meeting were not read.

2. Sir Hassan Suhrawardy having explained the present position as regards the purchase of the Commercial Road site, an authority to him to conclude the purchase, the price stated being $f_{2}, 800$, was signed by the Trustees present, and the Hon Secretary was instructed to obtain the signatures of Sir Frederick Sykes and, if possible, of $\mathrm{H} \mathrm{H}$ the Aga Khan.

\footnotetext{
${ }^{112} \mathrm{~A}$ muezzin is mentioned here for the first time in the Minutes. This is the man who gives the call to prayer, usually, but not always, from a minaret.

${ }^{113}$ Not included in the Minutes.
} 
3. The honorarium of $\mathcal{E}$ io to be paid to Mr A Bird from the London Mosque Fund was sanctioned. A testimonial to be given to Mr Bird in recognition of the valuable work he had done for the Mosque Fund, along with the British Red Crescent Society and the Indigent Muslims Burial Fund, was approved and signed by the Trustees present.

4. The secretarial charges since the handing over of charge as Assistant Secretary by Mr A Bird having been met in the first place from Sir Hassan Suhrawardy's pocket, it was agreed to sanction the employment of a paid stenographer at 30/- [shillings] a week, with effect from the I January, I940, the cost being met as one third (Io/-) each by the London Mosque Fund and the other two associated Societies. It was decided that after 30 June the employment of the stenographer should be extended quarterly until other arrangement could be made.

5. There being no further business, the meeting closed with a vote of thanks to Lord Lamington.

Confirmed: F. Sykes 6 January I94I

\section{Minutes of the Trustees of the London Mosque Fund held at II am on Monday 6 January g4I at India House, Aldwych, WC2}

Present:

The Rt Hon Major-Gen Sir Frederick Sykes (in the Chair)

Malik Sir Firozkhan Noon

Al-Haj Sir Hassan Suhrawardy

Apologies for absence were received from Sir Ernest Hotson and Mr Waris Ameer Ali.

I. The Minutes of the meetings dated 24 May and I9 July I940 were read and confirmed.

2. The Trustees placed on record their deep sense of appreciation of the devoted services rendered by the late Lord Lamington in maintaining the activities of the London Mosque Fund, and they also recorded their condolences with the bereaved family. It was noted that a letter of condolence had been sent to Lady Lamington on i8 
September, jointly by Sir Hassan Suhrawardy and Sir Ernest Hotson and a wreath was also sent on the day of the funeral.

3. It was resolved that the election of a Vice-President in place of the late Lord Lamington be postponed for consideration at a later date.

4. The question of the election of a Chairman of the Executive Committee was considered in the light of paragraph i of the Deed of Trust, to which attention had been drawn by the solicitors of the Fund.

Sir Hassan Suhrawardy proposed, and Sir Frederick Sykes seconded that, pending the amalgamation of the Fund with the bigger London Mosque (Jamea) Fund, Sir Firozkhan Noon be appointed Chairman. Sir Firozkhan pointed out certain difficulties in acceding to the proposal, and stated that he had consulted Mr Waris Ameer Ali on the subject and they considered that the election of Sir Hassan Suhrawardy would be most expedient. It was therefore unanimously resolved that Sir Hassan Suhrawardy be elected Chairman of the Executive Committee.

5. Sir Hassan Suhrawardy reported the purchase of properties Nos. 450/448/446 Commercial Road EI, which was completed by our solicitors, Messrs Cardew-Smith \& Ross, in December i940, at a total cost of $\AA_{2}, 800$ (No. $45^{\circ}$ being purchased for $\mathcal{E} \mathrm{I}, 05 \mathrm{O}$, and Nos. $446 / 448$ for $\left.\mathcal{E}_{1}, 75^{\circ}\right) .{ }^{114}$ This amount is $\mathcal{E}^{2} 200$ less than the stipulated amount of $£ 3$, Ooo for which Sir Hassan Suhrawardy was authorised to purchase the property (vide resolution dates 20 May 1940).

Legal disbursements in negotiating and purchasing the property amounted to f.48.4.- and the cost of postage, telephone calls, etc. amounted to $\delta_{2.2}$.- for which a statement has been received from our solicitors, and the amounts paid.

Under the Statutory Scale, Messrs Cardew-Smith \& Ross were entitled to a fee of $£ 25.6 .8$ for their professional services but they have made no charge.

Messrs Cuthbert, Lake \& Sutton, surveyors, submitted a bill for $£ 36.5 .2$ for professional services, which was duly paid.

\footnotetext{
${ }^{114}$ The purchase of $446 \& 448$ Commercial Road was completed on 20 December I940. See ELM Archives, Trust's solicitors to Suhrawardy, 2I December i940.
} 
It was resolved that the thanks of the Trustees be conveyed to Messrs. Cardew-Smith \& Ross for giving their honorary services to the Fund.

6. The Committee considered the following items:

a) Sir Hassan Suhrawardy's proposal to give up renting the dance hall at $85-87$ Commercial Road for the holding of prayers and religious observances, and to utilise the newly-bought premises for these purposes.

b) The application made by our solicitors for exemption of rates and taxes in respect of the above properties as it was proposed to use them for religious purposes only.

c) The application of the Jamiat-ul-Muslimin dated ${ }_{5}$ November to be allowed to lease one of the buildings, and the draft resolution drawn up by our solicitors giving the terms and conditions under which the property could be leased out. ${ }^{115}$

After discussion, the Committee authorised Sir Hassan Suhrawardy to take necessary steps to obtain exemption for all the properties for the period they lie vacant, over and above the application already made regarding the properties to be used for religious purposes. They also authorised him to take necessary action regarding alterations and repairs to convert the buildings to provide a temporary place of worship and Islamic culture centre.

7. The Committee considered the question as to whether any of the buildings could be utilised in any way for welfare work among Indian seamen for the period of the war. Sir Firozkhan Noon stated that, as he was a Member of the Trust, he could not take any action in the matter as High Commissioner for India. The matter was therefore dropped.

8. Sir Hassan Suhrawardy presented a report regarding the present financial position of the Fund, which was noted by the Committee.

There being no further business, the meeting adjourned with a vote of thanks to the Chairman Sir Frederick Sykes.

Confirmed: Frederick Sykes 20 January 194I, and Suhrawardy 23July I94I

\footnotetext{
${ }^{115}$ The Jamiat-ul-Muslimin office was situated at 59 Canton Street, London Ei4, prior to moving to Commercial Road. For the proposed resolution granting the Jamiat-ul-Muslimin the lease of 450 Commercial Road for purely religious purposes for the consideration of the Trust's solicitors, see ELM Archives, draft enclosed with Suhrawardy's letter to the Trust's solicitors, I3 December i940.
} 
To Sir Hassan Suhrawardy

Re: Nos. 446, $448 \& 45^{\circ}$ Commercial Road E. I

We the undersigned Trustees of the London Mosque Fund hereby authorise and request you as our agents and on our behalf to enter into Contracts to purchase for the above Trust Fund the above premises from the respective owners thereof.

Dated that 29 day of July 1940

Signed: Firozkhan Noon 20/5/40

Lamington $24 / 5 / 40$

Waris Ameer Ali 24/5/40

F.H. Sykes

Aga Khan [handwritten - the above signatures being printed]

[ another signature, unclear]

The original authority, signed by the other Trustees, is in safe custody with the Fund's Solicitors, Messrs, Cardew-Smith \& Ross, 27 Ely Place, Er.

\section{Minutes of a Meeting of the Trustees of the London Mosque Fund held on Wednesday 23 July I94I in Sir Hassan Suhrawardy's room at the India Office, Whitehall SWI}

\section{Present:}

Al-Hadj Sir Hassan Suhrawardy (in the Chair)

The Rt Hon Sir Frederick Sykes

Malik Sir Firozkhan Noon

Mr Waris Ameer Ali

Sir Ernest Hotson (Hon Secretary)

Colonel Stewart F Newcombe* and Mr Chisholm of Messrs Feasey Hull \& Feasey, the Auditors of the Fund, were present as advisors.

I. The Minutes of the last regular meeting held on 6 January I94I were read and confirmed. 
2. The steps taken for the completion of the East London Mosque and the Islamic Culture Centre were reported, and Sir Hassan Suhrawardy, Colonel S.F Newcombe and His Excellency the Egyptian ambassador were appointed to examine the accounts of the expenditure incurred and to pass them for payment.

3. The audited accounts of the London Mosque Fund from i January I940 to 3I March I94I were presented and approved. A vote of thanks to the Auditors, who are auditing the accounts for only a nominal fee was passed.

4. It was decided that the cost of structural alterations should be met by the London Mosque Fund and that the cash grants approved by the Jamiat-ul-Muslimin, if finally accepted, should be applied towards the furniture and fittings and the expenditure on upkeep.

5. Regarding the appointment of the Jamiat-ul-Muslimin as Agents of the Funds for the arrangement of prayers and other religious observances, Mr Waris Ameer Ali asked if it was competent for the Trustees to delegate their powers. Sir Hassan Suhrawardy stated that the Charity Commissioners had examined the contract which was drawn up by our Solicitors, and have found no objection to it. It was pointed out that the scheme is in accordance with the terms of clause 9 of the Trust Deed. ${ }^{.16}$ The appointment of the Jamiat was approved.

6. Sir Hassan Suhrawardy reported that it is not intended to repair No. $45^{\circ}$ Commercial Road, which was damaged by enemy action; ${ }^{117}$ so long as this house is kept vacant and not used, no rates will be payable.

7. Sir Hassan Suhrawardy was asked to fix a date for the formal opening of the Mosque and Culture Centre with Mr Amery* and Lord Moyne, ${ }^{*}$ and it was hoped that an early day could be arranged before the return of Sir Firozkhan Noon to India. It was thought that a Friday would be suitable, and the time should be in the early afternoon. H E the Egyptian Ambassador should be asked to preside.

\footnotetext{
${ }^{116}$ Clause 9 of the Trust Deed states: 'The Trustees may in carrying out the provisions of this Deed co-operate with any other body state community society or association having objects altogether or in part to those of the Fund'. See ELM Archives, The London Mosque Fund Declaration of Trust, ig November 1926.

${ }^{117}$ These premises were damaged in late December I940/early January I94I by German bombing. The Trustees decided to carry out the necessary repairs and alterations required for the provision of suitable accommodation for congregational prayers; however, only the most essential repairs were sanctioned for No. 450, which had been leased out to the Jamiatul-Muslimin on a small rent. See ELM Archives, Suhrawardy's memorandum to Firozkhan Noon on the acquisition etc. of the premises, enclosed with his letter, 4 February I94I.
} 
8. It was agreed to invite $\mathrm{H} \mathrm{E}$ the Egyptian Ambassador and $\mathrm{H} \mathrm{E}$ the Minister of Saudi Arabia to become Trustees of the Mosque Fund to fill the vacancy caused by the death of Lord Lamington and an existing vacancy. This will bring the number of Trustees to the figure of 7 , authorised by the Trust Deed.

9. The constitution of the Working Committee for the London Mosque Fund was authorised to consist of the Chairman, the Hon Treasurer, the Hon Secretaries, the Egyptian Ambassador and a representative of the Jamiat-ul-Muslimin.

Io. The correspondence with the British Council ${ }^{118}$ was considered, and it was decided to accept with thanks the offer of a capital grant of $£$ IOO and a recurring grant of $£ 75$ for this year and if possible for subsequent years. It was hoped that the success of the Culture Centre would be such as to justify an increase in the recurring grant. The opening of a "B" account with the Bank of England for the Islamic Culture Centre Fund was approved, and the donors of certain subscriptions already received for this Fund were thanked.

I I. The constitution of a Working Committee for the Culture Centre was authorised, the membership to be similar to that of the Working Committee of the London Mosque Fund, with the addition of a representative of the British Council. Sir Hassan Suhrawardy stated that Mr Martin Blake had been nominated for this purpose by the British Council.

I2. The budget estimate for $194^{\mathrm{I}}-4^{2}$ was examined and passed. It was decided that the grant from the Mosque Fund to the Culture Centre should be $\mathcal{E}_{\mathrm{I}}$ a week, that is $£ 5^{2}$ instead of $£ 5^{\circ}$. Sir Hassan Suhrawardy reported that Miss Evans, who has been assisting him, would be leaving shortly for other work. Miss Evans was thanked for the work she has done, and good wishes for her success in her new career were expressed. The provision for the salary of a clerk was passed. Sir Hassan Suhrawardy stated that he hoped it would be possible, in view of the decrease in the amount of work, to effect some

\footnotetext{
${ }^{118}$ The British Council provided a grant and also a range of free publications for the Cultural Centre attached to the Mosque (see ELM Archives, British Council to the Secretary of the Cultural Centre of the East London Mosque, I7 March 1942). The India Office was supportive of the British Council's contribution to the running of the Cultural Centre because it was of the view that 'a cultural centre of the kind proposed run on the right lines would be a useful influence among Indians in the East End of London and that assistance from the British Council would give a good deal of satisfaction in Indian Moslem circles'. See BL, IOR, L/P\&J/I2/468, fo. I97, India Office to the Foreign Office, 4June I94I.
} 
economy on this head in the new arrangement which he proposed to make.

I3. The Treasurer's report was read and approved. It was decided that it should be suitably abbreviated before printing as the combined report of the Mosque Fund and linked Societies because of the cost of printing and paper.

I4. His Excellency the Egyptian Ambassador was elected VicePresident of the Board of Trustees, subject to his agreeing to serve. Sir John Woodhead, K.C.S.I, C.I.E,* was elected Hon Treasurer and his consent to give his services to the Fund was welcomed. It was resolved that the Bank of England should be notified of his appointment accordingly, and that the funds should be operated on his signature with that of one of the Trustees. Sir Ernest Hotson and Colonel Stewart F Newcombe, D.S.O. were elected Joint Hon Secretaries. The firm of Messrs Feasey, Hull \& Feasey were reappointed as Auditors.

I5. On the proposal of Sir Firozkhan Noon, seconded by Mr W. Ameer Ali, a vote of thanks was passed to Colonel Newcombe for the invaluable help he has given in the arrangements for the reconstruction of the Mosque premises.

I6. On the proposal of Sir Firozkhan Noon, seconded by Mr W Ameer Ali, a warm vote of thanks was passed to Sir Hassan Suhrawardy for the energy which he has displayed on behalf of the Fund, and for presiding at the meeting.

Signed:

H Suhrawardy

W Ameer Ali approved the Minutes on 23 January 1942

Lieutenant Colonel

Sir Hassan Suhrawardy O.B.E

3 November 1939

India Office

SWI

Dear Brother in Islam

I am glad to enclose IDUL FITR ${ }^{119}$ card and I wish to convey to you Jamiat-ul-Muslimin's desire to welcome you at the time of prayer.

Yours faithfully, for and on behalf of Jamiat-ul-Muslimin Hon Joint Sec.

\footnotetext{
${ }^{119}$ This feast (I'd, alternative spellings ' $\mathrm{Id} / \mathrm{Eid}$ ) is the celebration that takes place at the end of the Muslim month of fasting, Ramadan.
} 
Lieutenant Colonel

I3 January I94I

Sir Hassan Suhrawardy O.B.E

India Office

SW I

Dear $\mathrm{Sir}^{120}$

$\underline{\text { I'd al Adha }}^{\text {121 }}$

I beg to inform you that the Jamiat-ul-Muslimin usually receives from the London Mosque Fund the sum of $\varepsilon_{5} / \mathrm{IO} /$ - on the occasion of the I'd al Adha for renting the Hall for prayers.

I shall be obliged if you will kindly forward your cheque for the above sum at your convenience.

Yours faithfully

Hon Secretary.

36 Whitechapel Lane

EI

20 January I94I

Lieutenant Colonel

Sir Hassan Suhrawardy O.B.E

India Office

SWI

\section{Dear Sir}

I have the honour to inform you that io Muharram-al-Harram falls on 4 February and as usual the Jamiat-ul-Muslimin desires to commemorate the Day of A'Ashura for which your London Mosque Fund sends a cheque for the sum of $£ 15{ }^{122}$

\footnotetext{
${ }^{\mathrm{I}}{ }^{20} \mathrm{It}$ is worth noting that, in the earlier letter, he was addressed as 'brother in Islam'. Now he is referred to as 'Sir', a much more formal and distant form of address.

${ }^{121}$ This is the 'festival of the sacrifice' and marks the conclusion of the Hajj (or annual pilgrimage to the Holy Places of Islam). It marks the end of the rites that take place at Mina and takes place on the tenth day of the Islamic month of Hijja.

${ }^{122}$ Muharram is the first month of the Islamic Hijri calendar. The tenth day of the month (Ashura) is commemorated by Shia Muslims as a day of mourning for the martyrdom of Imam Hussain (the Prophet Muhammad's grandson) and his seventy-two friends and relatives at the Battle of Karbala in $680 \mathrm{CE}$.
} 
Please send this cheque at your earliest convenience and oblige. Yours faithfully Hon Secretary

India Office Whitehall SWI

The Hon Secretary

THE JAMIAT-UL-MUSLIMIN

36 Whitechapel Lane

EI

Dear Sir

With regard to my conversation on the telephone with Mr Allahdad Khan and Mr Qureshi regarding the donation for $\mathcal{E}_{\mathrm{I} 5}$ to enable the Jamiat to observe the anniversary of the martyrdom of Syedana Hazrat Imam Hossein on Friday 7 February, I have consulted other members of the London Mosque Fund at present available in London, and other prominent Muslims, and they are of opinion that the Mosque Fund, which at present has become very small on account of the purchase of the properties Nos. 446/448/450 Commercial Road, cost of repairs, payment of taxes, etc. should not be diverted for any other purposes.

I am therefore herewith enclosing a cheque for $\ell^{2.2 \mathrm{~s}}$ as my own personal contribution, and I am sure that if you approach other members of the Muslim community, they will also show their interest by making subscriptions for this purpose.

Yours faithfully

Sir Hassan Suhrawardy

Hon Treasurer \& Trustee

LONDON MOSQUE FUND

India Office

Whitehall

SWI

2 April I94I

Sahibdad Khan, Esq*

JAMIAT-UL-MUSLIMIN

36 Whitechurch Lane

EI

My dear Khan

I wanted to get into touch with you over the telephone to tell you that the less the number of speeches in a function, the better it is. In order 
to make it representative, it is very good for you to ask Mr Zada* ${ }^{* 23}$ to say a few words and also I shall try to get someone from the Egyptian Embassy to take part.

You should leave me out, both for reasons of my present health, and also as I have excused myself from other places it will not be nice for me to speak here. I am with you, and I am your friend, and I shall be very glad to be present and give all moral support. I trust that you will understand, and accept my suggestions.

Yours sincerely

Hassan Suhrawardy

\section{The first joint meeting of the Sub-Committees of the East London Mosque and Islamic Culture Centre was held in the Committee Room at 446 Commercial Road, Er on Thursday 14 August 194 I}

\section{Present:}

Sir Hassan Suhrawardy, in the Chair

Col S.F. Newcombe

Mr Said Amir Shah ${ }^{124}$

Mr Ahmaddin Qureshi

Dr A.J. Arberry* attended the meeting of the Islamic Culture Centre by invitation.

Apologies for absence were received from Sir Ernest Hotson, $\mathrm{Mr}$ Martin Blake, Mr W.D.H Danby, Mr A. Yusuf Ali, and Mr Mahmood R. Zada.

\footnotetext{
${ }^{12}$ Mahmood R. Zada.

${ }^{124} \mathrm{~A}$ secret British intelligence report described Amir Shah as one of the Shah brothers, silk merchants, warehousemen, and film agents from Amritsar, Punjab, who had also run 'somewhat doubtful' Indian boarding houses in London in the early i93os. In 1940, he began to take considerable interest in cases in which Indian seamen figured and he acted as official court interpreter. While a passionate proponent of India's independence, he was staunchly opposed to Soviet communism. Amir Shah had initially come to notice as representing East End Indians on the Executive Committee of the London Branch of the Indian National Congress, as a supporter of the nationalist V.K. Krishna Menon's India League, and 'generally as an agitator amongst East End Indians [...] It may be said that up to the opening of the Mosque there were indications that the Jamiat was politically inclined [...] Shah has made every possible effort to turn it into a political weapon'. In August I942, Amir Shah's political activities greatly increased, he taking part in meetings and collecting funds. While denounced as a pro-Fascist and a Black Marketeer by Menon, as a leading member of the Committee of Indian Congressmen in Great Britain he remained bitterly anti-Muslim League and condemned the Pakistan plan as a suicidal policy for Indian Moslems fostered by the enemies of Islam and India. See BL, IOR, L/P\&J/I2/468, fos $73-77$.
} 
I. The appointment of a Managing Committee. This is to consist of Muslim members only: Mr Said Amir Shah, Mr Ahmadddin Qureshi, nominees of the Jamiat-ul-Muslimin: Mr Mahmood R. Zada, Mr Kemal Lebbane* and Sir Hassan Suhrawardy, nominees of the London Mosque Trust, with powers to add to their number.

2. The programme of prayers and religious ceremonies was specified as follows: Prayers five times daily; Juma Prayers; 'Id Prayers; Ramadan Tarawi Prayers; ${ }^{125}$ Milad-i-Nabi, Ashura and any other religious meeting.

3. The appointment of Mr Naqibullah Nairullah as resident caretaker was confirmed. His duties were to include the following: (a) to arrange for all Prayers and religious observances as listed above, under the supervision of the Jamiat-ul-Muslimin; ${ }^{.126}$ (b) to look after the furniture, etc. in each room, of which he will prepare an inventory, sending one copy to the Jamiat-ul-Muslimin, one copy to the Secretary of the London Mosque Fund, and one copy he will keep himself.

4. Mr N. Nairullah was asked to prepare a statement in detail of the cooking apparatus required to be placed in No. $45^{\circ}$ in the basement, and then obtain an estimate and forward it to Colonel Newcombe for consideration by the Trustees of the London Mosque Fund.

5. That the Trustees of the London Mosque Fund be approached to sanction an honorarium of $\delta 4$ per month for the pesh namaz of the Mosque. And that Al-Hadj Hafiz Muhammad el-Shami be recommended to them for this appointment.

6. In any matter requiring financial assistance, a joint meeting of the Managing Committee and the Sub-Committee of the London Mosque Fund will be convened. Otherwise the Managing Committee will function independently.

As regards the Islamic Culture Centre, the following resolutions were passed.

\footnotetext{
${ }^{125}$ 'Tarawi Prayer', also written Tarawih, is the special prayer performed only in the month of Ramadan. It takes place every night after the isha or nightly regular prayer. In many mosques, one-thirtieth of the Qur'an is recited during this prayer, so that over the month of Ramadan the whole Qur'an is recited. Tarawi is not compulsory, but is Sunnah - that is, a recommended activity - since it is believed that the Prophet Muhammad performed it himself.

${ }^{126}$ This Minute suggests that the Jamiat-ul-Muslimin were in charge of the service provided by the caretaker.
} 
I. That Mr Mahmood R. Zada and Mr Kemal Lebbane be invited to take on the direction of the Islamic Culture Centre with Dr Arberry, Mr Amir Shah and Mr Ahmaddin Qureshi, representatives of the Jamiat-ul-Muslimin, to be members of a Managing Committee to assist them, with powers to add to their number.

2. Lectures on Islamic Culture (usually in English) would be arranged for monthly or bi-monthly meetings; lectures to be free, and no refreshment arranged for except by the Committee's decision. The subjects and lecturers are to be selected by the Managing Committee.

3. A letter to Sir Hassan Suhrawardy from Mr Ikbal Ali Shah was considered, in which it was proposed that the Centre could:

i) Interpret Islam as a Social Force

ii) Correct misconceptions about Islamic ideals and suggest methods to achieve these objectives.

These aims set forth by Mr Shah were substantially the same as those the Committee had decided to follow, and it was therefore resolved to thank him very much for his interest. As he is now living in Oxford, Dr Arberry was requested to consult him about the subject on which he could be invited by the Committee to lecture.

The other points raised in Mr Ikbal Ali Shah's letter will be considered by the Managing Committee at their next meeting.

4. That Al-Hadj Hafiz Muhammad el-Shami be asked to give one hour's lesson to adults and one hour to children on the religion of Islam on Thursdays (or other agreed day) and £i2 per annum was suggested as his honorarium to begin with. A school for Muslim children can be considered after the Islamic Culture Centre is well established.

5. That a quarterly bulletin should be issued, called "The East London Mosque and Islamic Culture Centre News Bulletin" or any other suitable name to be decided upon by the Managing Committee.

6. The offer of "Great Britain \& the East" to send a weekly copy of that journal was gratefully accepted.

Colonel Newcombe was requested to arrange with the British Council for the free supply of newspapers, periodicals and books. Dr Arberry was requested to arrange for a free supply of publications in Arabic, Urdu, Persian and other Oriental languages.

7. In any matter requiring financial assistance, a joint meeting of the Managing Committee and the Sub-Committee of the London 
Mosque Fund will be convened, otherwise the Managing Committee will function independently.

There being no further business, the meeting closed with a vote of thanks to the Chair

Signed: H Suhrawardy i8 August i94I

Confirmed: A Yusuf Ali 28 November I94I

\section{The London Mosque Fund}

At the Meeting of the Trustees held on Wednesday 23 July I94I at which Sir Hassan Suhrawardy took the Chair, the following was noted in the Minutes :

"Sir Hassan Suhrawardy reported that Miss Evans, who has been assisting him, would be leaving shortly for other work. Miss Evans was thanked for the work she has done, and good wishes for her success in her new career were expressed. The provision for the salary of a clerk was passed. Sir Hassan Suhrawardy stated that he hoped it would be possible, in view of the decrease in the amount of work, to effect some economy on this head in the new arrangement which he proposed to make".

With the establishment of the East London Mosque and Islamic Culture Centre, the correspondence and book-keeping which had been heavy during the last eighteen months, has now decreased considerably, and it is suggested that the honorarium of the new clerk should be fixed at $\mathcal{E}^{2}$ a month, of which $\mathcal{E}^{\mathrm{I}}$ should be paid from the British Red Crescent Society, the funds of which have no recurring expenditure, but which will be re-organised and most of the work will be for this Society. The London Mosque Fund and the Indigent Muslims Burial Fund, the work has been reduced to such an extent that Io/- a month would be quite a reasonable honorarium from each of these funds at present. Mrs W Gatcombe, a part-time stenographerclerk at the India Office, has been temporarily appointed, and Miss Evans has undertaken to show her the work.

It is requested that the Trustees should sign below if they approve of the above resolution.

Signatures:

Hassan Suhrawardy, Firozkhan Noon, Frederick Sykes, Waris Ameer Ali I9 August I94I 


\section{The London Mosque Fund}

At the Annual General Meeting of the Fund held on Tuesday i7 May, I938, at which Lord Lamington took the Chair, the following resolution was passed:

"It was proposed by Sir Abdul Qadir and seconded by Mr Waris Ameer Ali that an Honorarium of $f_{\text {I }}$ per week be paid to Mr Hasan for leading Friday prayers etc in the East End of London. One month's notice to be given by either side to terminate the arrangement. This was agreed to".

Following the establishment of the East London Mosque and Islamic Culture Centre, the duties and responsibilities of the Pesh $\mathrm{Namaz}^{127}$ who leads the prayers have increased very much, as instead of arranging only for Friday prayers once a week and 'Id prayers, we have in addition now arranged for prayers five times a day, and also for Tarawi prayers during the whole month of Ramadan.

It is therefore proposed that the honorarium of the pesh namaz should be fixed for $£ 4$ per month for the duties stated above, and the Jamiatul-Muslimin have been asked to persuade the pesh namaz - Al-Hadj Hafiz Muhammad el-Shami - not to ask for more at the present time.

At a meeting of the Sub-Committee held on I3 August, I94I, it was resolved that Al-Hadj Hafiz Muhammad el-Shami should be given an honorarium of $\oint_{\text {I }}$ per month from the Islamic Culture Centre for giving religious instruction, and this would bring his total honorarium up to $£ 5$ per month.

It is requested that the Trustees should sign below if they approve of the above Resolution.

\section{Signatures:}

Hassan Suhrawardy, Firozkhan Noon, Frederick Sykes, Waris Ameer Ali I9 August I94I

${ }^{127}$ 'Prayer leader' (Persian). 
Minutes of a meeting of the Trustees of the London Mosque Fund held at India House on Friday 12 September I94I at 12 noon

Present:

Sir Frederick Sykes

Sir Firozkhan Noon

W. Ameer Ali

With Sir John Woodhead (Hon Treasurer)

And Sir Ernest Hotson (Hon Secretary)

I. In the absence of the Chairman, Sir Hassan Suhrawardy, Sir Frederick Sykes was asked to take the Chair.

2. The Confirmation of the Minutes of the last regular meeting was postponed until the next meeting, this being a special meeting and time available short.

3. Owing to difficulties arising from slowness of communication and to absence of H H the Aga Khan in Switzerland and Sir H Suhrawardy on leave in India, and the early departure of Sir Firozkhan Noon, who is not likely to be succeeded at once by another Moslem as High Commissioner, it was decided that the number of Trustees should be increased at least temporarily, so as to ensure the presence of a quorum of three at meetings. The usual number of ordinary Trustees is five, to whom the Moslem Advisor to the Secretary of State for India and the High Commissioner for India, when a Moslem, are added ex officio. Of these, Lord Lamington has died and Sir Frederick Sykes desires to resign owing to the pressure of his other duties. The following were therefore elected Trustees, subject to their acceptance of office - Subhi Bey Ozbekhan, Commercial Counsellor, Turkish Embassy; Hussain Said Bey, First Secretary and Counsellor, Egyptian Embassy; A. Yusuf Ali, C.B,E.; Lord Winterton, M.P**

The Hon Secretary reported that Sir Hassan Suhrawardy had been in correspondence with the first three of these gentlemen before his departure for India, and that there was good reason to believe that they would accept. He himself had been in correspondence with Lord Winterton and hoped for a final and favourable reply within a few days. The Hon Secretary was instructed to write again to Mr Yusuf Ali and to arrange to call personally on Subhi Bey and Hussain Said Bey if their replies were further delayed. 
4. The resignation of Sir Frederick Sykes was accepted with much regret and he was warmly thanked for all the assistance he has given the Fund. It was, however, agreed that his resignation should not take effect until a sufficient number of the newly elected Trustees have accepted office to ensure a quorum.

5. The Trustees approved of the sale of India $3 \frac{1}{2} \%$ stock to the face value of $£^{15}$ I5.7.I which had been arranged by the Chairman through the Bank of England to furnish cash for the payment of charges incurred in the purchase and reconditioning of the Mosque site. The fact that these charges were due and that securities would have to be sold in order to pay them was mentioned at the last meeting of the Trustees, but a formal resolution was not then passed.

6. The Hon Treasurer reported that some other small accounts were still unpaid and he was authorised to pay them, provided that they were not of large amounts and that cash was available.

7. The Hon Treasurer was authorised to pay the Insurance premium on the Mosque premises to the Guardian Assurance Co. Ltd. after Col. Newcombe has examined and approved of the policy. The Hon Treasurer understood that the premium would be $13 / 6 \mathrm{~d}$ in the first year and $£ 2.6 .6$ in subsequent years.

8. The Hon Treasurer and Hon Secretary were instructed to look into the question of war Insurance. It was understood that the premises were subject to compulsory insurance and that the chattels belonging to the Mosque would probably fall under the voluntary insurance scheme. The Hon Treasurer and Hon Secretary were empowered to pay such premia as might be found due.

9. Sir Firozkhan Noon suggested that the Mosque should be named "The Ameer Ali Mosque", the name "East London Mosque" not being sufficiently distinctive. The Trustees regarded this proposal favourably and directed that it should be brought up again at a later meeting after steps had been taken to sound the opinion of the Jamiatul-Muslimin and others.

Io. There being no other business, the meeting closed with a vote of thanks to the Chair and to Sir Firozkhan Noon for his hospitality and an expression of sincere regret at Sir Firozkhan's departure from London, with good wishes for his happiness and success in his future career.

Approved: 23January I942 W. Ameer Ali 


\section{The Trustees of the London Mosque Fund}

The following gentlemen have accepted office as Trustees of the London Mosque Fund:

The Rt Hon Earl Winterton, M.P

A. Yusuf Ali, Esq, C.B.E

Husain Said Bey Esq (addressed as Monsieur H.M Said), Counsellor, the Royal Egyptian Embassy

Mahmood R. Zada Esq, Counsellor, Saudi Arabian Legation

Bey Ozbekhan, of the Turkish Embassy, who was elected a Trustee at the meeting held on I2 September I94I, having been unable to accept office, an invitation was sent, after consultation with those of the Trustees who were accessible, to Mr Mahmood R. Zada, who has been kind enough to agree to become a Trustee.

At the meeting on I2 September 194I the resignation of Sir Frederick Sykes was accepted on the condition that it should not take effect until a sufficient number of the newly elected Trustees had consented to serve. That condition has now been fulfilled, and the resignation of Sir Frederick Sykes has therefore come into force. The Trustees have expressed their great regret that his manifold other duties have made it impossible for him to continue to assist the Trust.

There is at present no business requiring the immediate attention of the Trustees, but a meeting will be convened as soon as such business arises.

[handwritten next to this page]

Trustees as on I November [writing unclear] I94I

I. $\mathrm{H} \mathrm{H}$ the Aga Khan $(\ldots \ldots \ldots$. Trustee)

2. Sir Hassan Suhrawardy $(\ldots \ldots$ the Trust Deed $)$

3. Waris Ameer Ali $(\ldots \ldots \ldots \ldots \ldots \ldots$ dated $9 / \mathrm{I} / 4 \mathrm{I})$

4. Yusuf Ali

5. Lord Winterton $(\ldots \ldots \ldots \ldots)$

6. Husain Said Bey, Counsellor, Royal Egyptian Embassy (...)

7. Mahmood R Zada, Counsellor, Saudi Arabian Legation (formally .............) 
Stepney Green

I948

Dear Mr Ali

Assalam $\mathrm{O}$ alaikum. ${ }^{128}$ Many thanks for your telegram and the money. We missed you very much yesterday. I am glad to inform you that nearly 500 people were present and the luncheon was provided by His Majesty, King Farouk of Egypt through the Egyptian Ambassador in London.

I am sorry you are away as there are not many people here now and all the work has to be done by few men available. There is such a lot to do in the new place.

I read your telegram to members of the Committee and I herewith send their fraternal greetings on the happy occasion of Bairam and their appreciation of your spirit of Khidmat. ${ }^{129}$

May You be spared many a years [sic] to do something for $\operatorname{Din}^{130}$ al Baraka. ${ }^{13 t}$

Wasalam $^{132}$ and my personal regards to you and your family.

Yours fraternally

Hon Secretary

\section{Proceedings of a Joint Meeting of the Working (Sub) Committee of the East London Mosque and the Islamic Gulture Gentre held at the India Office on Friday, 28 November I94I}

Present:

Mr A Yusuf Ali (in the Chair)

Mr Mahmood R. Zada

\footnotetext{
${ }^{128}$ This was the first time an Islamic greeting entered correspondence included in the Minutes in this way.

${ }^{129}$ 'service'.

${ }^{130}$ 'religion'.

${ }^{\mathrm{I} 3 \mathrm{I}}$ 'blessing/the blessed' (i.e Islam).

${ }^{132}$ 'and peace' (also written wa salam).
} 
Mr Kemal Lebbane

Mr Gray (representing the British Council)

Mr Said Amir Shah

Mr Ahmaddin Qureshi

Sir Ernest Hotson

Colonel Newcombe

Sir John Woodhead

Dr Arberry sent his apologies for being unable to attend.

I. The minutes of the meeting held on I4 August I94I were confirmed.

2. The following items of expenditure were confirmed:

Item

a) Commercial Gas Co.

b) Electric Light Co.

c) Telephone Charges

d) Charges for water

e) Miscellaneous expenses

f) Notepaper and dies for the Culture Centre

\begin{tabular}{|c|c|}
\hline Date of Cheque & Amount \\
\hline & E. s.d \\
\hline 23 July I94I &.- II. 3 \\
\hline 22 Nov I94I & $5 \cdot 14 \cdot 5$ \\
\hline I4 Nov I94I & I.I6.IO \\
\hline 6 Oct I94I & $3 \cdot 5 \cdot 3$ \\
\hline I4 Nov I94I & 2. 8.5 \\
\hline 20 Sept I94I & 3.17 .8 \\
\hline I8 Nov I94I & 7.10. o \\
\hline 2I Nov I94I & 34. I. 6 \\
\hline 2I Nov I94I & $3 \cdot 4 \cdot 4 \%$ \\
\hline
\end{tabular}

2I Nov i94I
I. $6 .-$

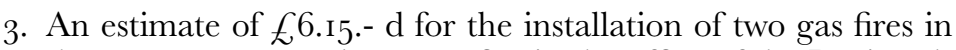
the prayer room and one gas fire in the office of the Jamiat-ulMuslimin was approved.

4. The Hon Treasurer informed the meeting that the annual expenditure on account of the Mosque would exceed by at least $f_{6} 5$ the amount provided in the budget. This was due to a) No provision having been made for the sum of $£ 4^{8}$ payable to $\mathrm{Al}$ Hadj Hafiz Mohammed-el-Shami as Pesh Namaz of the Mosque, and, b) the expenditure on heating, lighting etc being nearer $£ 40$ than $\mathcal{E}_{20}$, the amount provided for in the budget. After 
considerable discussion the following changes in the budget were approved-

i) the provision for religious observances and prayers to be reduced from $£_{5} 6$ to $£_{3} 6$ by omitting the sum of $£_{15}$ for the Ramazan ${ }^{133}$ and Tarawi prayers and reducing the sum for the Milud-e-Nabi from $£ 20$ to $£ \mathrm{I} 5$.

ii) The payment to $\mathrm{Al}$ Hadj Hafiz Mohammed-el-Shami to be reduced to $£ 30$ a year, the reduction being accompanied by an increase in the payment to this person from the funds of the Culture Centre from $f_{12}$ to $f_{3} \mathrm{O}$. The payment of $\AA_{3} \mathrm{O}$ from the funds of the Mosque should be described as for "the teaching of the Koran" and not for "the leading of the prayers".

Mr Amir Shah informed the meeting that in view of the funds the Jamiat-ul-Muslimin had received for this year's Id-ul-Fitr, they would be in a position to refund the grant of fio.ro.-d provided for in the budget for that festival. In order, however, to make it quite clear that this grant would in all probability be required in future years, he proposed that a cheque for the grant should issue this year which would be refunded by the Jamiat-ul-Muslimin. The meeting agreed to this and placed on record their appreciation of the action taken by the Jamiat-ulMuslimin.

5. The Hon Treasurer mentioned that correspondence in regard to the registration of the buildings as a place of public worship was continuing and it was hoped that the registration would shortly be completed. This would entitle the Trustees to a reduction in the rates and taxes payable on the premises. This relief would however, only operate from the date of sanction and no refund of payments already made would be obtainable.

6. The question of the provision of a loud speaker was discussed. Mr Amir Shah explained that one was necessary on important festivals for on these occasions the number of persons attending the prayer was large and in addition to the prayer room the sheds at the back were used for prayers. The cost of a loud speaker is, however, considerable and it was accordingly decided that further enquiries should be made before expenditure on a loud speaker was incurred. Colonel Newcombe kindly promised to

\footnotetext{
${ }^{133}$ Alternative spelling of 'Ramadan'.
} 
investigate the matter by getting into touch with experts as to the most economical means of solving the problem.

7. As regards further capital expenditure on the present buildings the Hon treasurer said that funds were not at present available for expenditure on improvements on the present buildings Securities to the value of $£, 1,500$ were sold a few months ago in order to provide for alterations and decorations to the present buildings and when all the bills had been paid the unspent balance of this sum would be small. The question of further capital expenditure on the present buildings had therefore resolved itself. It was agreed that there was no possibility of the present buildings being replaced by new buildings till some time after the war.

8. As regards the expenditure of the grant of $£ 75$ by the British Council, Mr Gray (representing the Council) informed the meeting that

(I) the grant could be spent on:

i) the teaching of English to Moslems

ii) books and papers other than religious books and papers

iii) films

iv) gramophones and records

v) lectures on subjects other than religious subjects

vi) a reasonable amount on the remuneration of the person for looking after the reading room and library

(2) the Council would provide free of charge, that is over and above the grant of $£ 75$, periodicals and newspapers

(3) the Council might be able to provide lecturers. It was decided that:

(a) Mr Yusuf Ali and Colonel Newcombe be requested to prepare a list of books and papers to be acquired under (i), (ii) and (2) above.

(b) A teacher of English should be appointed provided a sufficient number of "scholars" were available. Colonel Newcombe said he was already in touch with the British Council in regard to this matter.

(c) Mr Mahmood R. Zada and Mr Kemel Lebbane be requested to take in hand the matter of lectures in consultation with the British Council. 
9. Some members of the Committee mentioned the need for printed prayer cards. The Committee was, however, informed that the Woking Mosque had printed a large number of these cards and in all probability would be able to supply them, probably free of charge.

Io. In connection with the resolution framed at the meeting held on I4 August 194I, in regard to the aims of the Culture Centre the Meeting was of opinion that the main activities of the Centre would be the education and welfare of Moslems in East London. There are no opportunities of the Boy Scout Movement at present since nearly all the children have left London. On the question of the name of the Culture Centre, which some members considered inappropriate, the Committee were of opinion that it would be better to call it simply the "Islamic Centre".

Confirmed: H Suhrawardy 3 July I942

\section{Minutes of the meetings of the East London Mosque Trustees and Executive Committee held on Friday, 23 January I942 at I r.30 a.m}

Present:

Mr Waris Ameer Ali, C.I.E (in the chair)

Earl Winterton, M.P

Monsieur H.M.Said

Mr Mahmood R. Zada

with

Sir John Woodhead

Colonel S.F Newcombe

Sir Ernest Hotson

and

Mr K Lebbane

The minutes of the meetings of the Trustees held on 23 July and 12 September were read and confirmed. 
The assumption of office as a Trustee by Mr A. Yusuf Ali was recorded.

A letter of apology for absence from Mr A. Yusuf Ali was read. In it he expressed a desire to resign his Trusteeship on the ground of ill-health. The Hon Secretary was directed to inform him that the Trustees were most anxious that he should not resign and hoped that his health would enable him to resume his duties very soon.

Lord Winterton and Monsieur Said were welcomed and their assumption of office as Trustees recorded.

On the proposal of Mr Ameer Ali, seconded by Lord Winterton, Mr Mahmood R. Zada was elected a Trustee.

The resignation of Sir Firoz Khan Noon on his return to India was recorded with regret. The resignation of Sir Frederick Sykes, reported at the meeting on I2 September but postponed at the request of the Trustees, was recorded with regret.

It was recorded with regret that their Excellencies the Egyptian Ambassador and the Saudi Arabian Minister had been unable to accept an invitation (vide the meeting of 23 July i94I) to become Trustees.

The Hon Treasurer pointed out that the Trust Deed vested the general administration of the income of the London Mosque Fund in an Executive Committee which, owing to recent changes in the personnel, had almost ceased to exist and had not held meetings for some time. Its place had temporarily been taken by a Working Committee (or Sub-Committee). It was agreed to re-establish the Executive Committee and to instruct it to take over the duties recently performed by the working (Sub) Committee. On the proposal of Lord Winterton, seconded by Monsieur Said, the following gentlemen were appointed to Executive Committee:-

a) Sir Hassan Suhrawardy (Chairman)

Mr Yusuf Ali (Chairman during Sir Hassan's absence)

Mr Ameer Ali

Mr Mahmood Zada (Trustee)

b) Mr K. Lebanne

c) Messrs. Amir Shah and Ahmaddin Qureshi (representing the Jamiat-ul-Muslimin)

d) Dr Arberry

e) A representative of the British Council when business concerning the Council is under consideration.

f) Sir John Woodhead Sir Ernest Hotson and Colonel Newcombe. 
The meeting of the Trustees was then suspended and a meeting of the Executive Committee took place.

An invitation to attend had been given to Messrs. Amir Shah and Ahmaddin Qureshi but they regretted that they were unable to be present because the hour coincided with that of Friday prayers at the Mosque. ${ }^{134}$

Sir Ernest Hotson and Colonel Newcombe were appointed Joint Hon Secretaries and Sir John Woodhead was appointed Hon Treasurer.

The Hon Treasurer reported that on 23 July i94I the Trustees had decided that owing to difficulties of communication due to the war, cheques should be signed by the Hon Treasurer and one Trustee, whereas Rule I7 of the Executive Committee's body of rules required the signatures of the Hon Treasurer and two Trustees. On the proposal of Mr Mahmood R. Zada seconded by Mr Lebbane it was agreed to amend Rule $\mathrm{i} 7$ in accordance with the decision of the Trustees.

The Executive Committee was informed that under arrangements made by Sir Hassan Suhrawardy two Managing Committees had been formed to manage the affairs of the Mosque and of the Islamic Centre connected with the Mosque. It was agreed to continue this arrangement and that the Mosque Managing Committee should consist only of Moslems ${ }^{135}$ with the assistance of the Hon Secretaries and Hon Treasurer. The following Managing Committees were appointed:

a) Mosque Managing Committee

Sir Hassan Suhrawardy (Chairman)

Mr Yusuf Ali (Acting Chairman during Sir Hassan Suhrawardy's absence)

Mr Mahmood R. Zada

Mr Lebbane

Mr Amir Shah

Mr Ahmaddin Qureshi

b) Islamic Centre Managing Committee

Mr Mahmood R. Zada

Mr Lebbane

\footnotetext{
${ }^{134}$ It is curious that the meeting was taking place at prayer time, when devout Muslims would not be able to attend. It would seem that the Jamiat-ul-Muslimin adhered to the rituals of Islam more stringently and literally than did the Trustees. This may indicate a degree of friction between the two groups.

${ }^{135}$ This was the first time that non-Muslims had been excluded from a committee, presumably for religious reasons.
} 
Mr Amir Shah

Mr Ahmaddin Qureshi

Dr Arberry

A representative of the British Council

with the Joint Hon Secretaries

and the Hon Treasurer

The meeting of the Trustees was then resumed and on the proposal of Monsieur Said, seconded by Mr Mahmood R. Zada, the amendment of rule I7 which had been passed by the Executive Committee was approved so as to require the signature of cheques by the Hon Treasurer and one Trustee instead of two.

A joint meeting of the Trustees and the Executive Committee was then held.

The Hon Treasurer reported on the financial position (vide statements attached at the end of the minutes) and the following expenditure incurred between I April and 3I December I94I was approved:

\section{LONDON MOSQUE FUND}

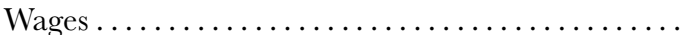

Gas, Electricity \& Telephone................. $\quad$ \& 23.II. 2

Contribution to Islamic Centre.................

Insurance...............................

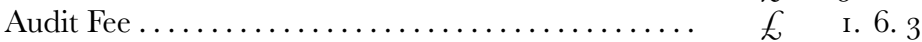

Rates \& Taxes..........................

Contribution for religious ceremonies............ $\mathcal{E}_{\text {2I. - . - }}$

Miscellaneous Expenditure .................. \& $\quad$ 47.10.7

Furniture and fittings...................... $\quad \& \quad$ I55.I5.5

Repairs and improvements to the property

in Commercial Road......................... £ I375.I4.8

\section{ISLAMIC GENTRE}

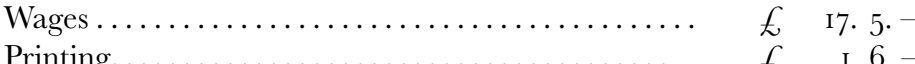

The estimates of receipts and expenditure for the year i94I/2 were also approved on the motion of Mr Mahmood R. Zada, seconded by Monsieur Said. In this connection the Hon Treasurer pointed out that accurate estimates of expenditure under several heads could not be made without further experience of the actual cost. 
On the proposal of Lord Winterton, seconded by Mr Mahmood R. Zada the transfer of $\mathcal{E}_{\mathrm{I}}$ Ioo from the Islamic Centre to the Mosque Fund to cover expenditure already incurred by the latter on behalf of the former was approved.

The need for whitewashing the exterior of the premises was mentioned and admitted, but in view of the financial position it was decided to postpone the work for some months.

Mr Ameer Ali proposed and Monsieur Said seconded a vote of thanks to Sir John Woodhead, Col. Newcombe and Sir Ernest Hotson for work they had done on behalf of the Mosque, the great economies which had been effected by the personal attention of Col. Newcombe to the alterations and decoration of the Mosque and the premises being specially mentioned.

Col. Newcombe also reported steps which were being taken to provide for the welfare of Moslems in London and other cities in this country.

The proceedings then terminated with votes of thanks to Mr Ameer Ali for presiding and for his many labours on behalf of Moslem welfare and to Sir John Woodhead for having arranged for the meeting to take place in the India Office.

Confirmed: Suhrawardy [? writing unclear] I5June 1942

\section{Approved at the meeting of the Trustees and Executive Committee held on 23 January 1942}

ISLAMIC GENTRE

$\begin{array}{lrcc} & \mathcal{E} & \mathrm{s} & \mathrm{d} \\ & 75 & - & - \\ \text { British Council } & \mathrm{I} 5 & - & - \\ \text { Sir Hassan Suhrawardy } & \mathrm{I} 5 & - & - \\ \begin{array}{l}\text { Mr Yusuf Ali } \\ \text { Messrs Shah Bros }\end{array} & 25 & - & - \\ \begin{array}{l}\text { Contribution from } \\ \text { London Mosque Fund }\end{array} & 52 & - & - \\ \begin{array}{l}\text { Amount collected up to I928 } \\ \text { for the library and lecture room fund }\end{array} & 22 . & \text { IO. } & \text { I } \\ \text { BALANCE } & 204 . & \text { I0. } & \text { I }\end{array}$


Telephone, Electricity and Gas

Water Rate

\begin{tabular}{rrr}
$f$ & s & d \\
II. & - & - \\
$5 \cdot$ & - & - \\
30. & - & - \\
44. & $4 \cdot$ & - \\
I0O. & - & - \\
204. & IO & I \\
\hline
\end{tabular}

[handwritten at the top]: The Treasurer's Report as placed before the Meeting of the Trustees and Executive Committee held on 23January I942

I. On 3i December i94I the cash balances were-

(i) London Mosque Fund $\quad £ 402 . \quad$ I9. 6

(ii) Islamic centre $\quad £ 300 . \quad$ I9. 6

2. $3 \frac{1}{2} \%$ India Stock to face value of $\oint_{1}$ I5 5.7.Id held by the Trustees of the London Mosque Fund was sold in August I94I in order to wipe out a debit balance of nearly $£ 400$ and to provide funds for meeting the balance of the cost of repairs and improvements to the property in Commercial Road.

The repairs have been completed and final bills paid.

3. The balance at the credit of the Islamic Centre includes $f_{\text {ioo }}$ which was received as a grant from the British Council towards the non-recurring expenditure on the Reading Room and Library. The expenditure actually incurred has exceeded fIoo and the British Council has agreed that the items included within the actual expenditure are correctly debitable against the grant. No part of this expenditure has been debited to the Islamic Centre Fund but has been met entirely out of the

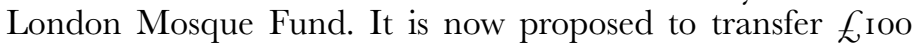
from the Islamic Centre Fund to the London Mosque Fund.

4. Statements are attached showing:

i) the estimated annual receipts and expenditure of the London Mosque Fund 
ii) the estimated receipts and expenditure in $194 \mathrm{I} / 42$ of the Islamic Centre

i) The estimated yearly receipts and expenditure of the London Mosque Fund:

The Expenditure side is incomplete because it does not include expenditure of a) rates and taxes, excluding Water Rate, and b) miscellaneous expenditure. It is hoped that the property will be exempted very largely, if not entirely, from rates and taxes (other than the Water Rate) but until the decision of the taxing authorities is known it is impossible to forecast the expenditure under this head.

As regards miscellaneous expenditure, it is impossible to forecast the amount - it will probably be considerable. Everything points to a considerable excess of expenditure over receipts but it is impossible at present to say what this excess will be.

ii) The estimated receipts and expenditure in $\mathrm{I} 94 \mathrm{I} / 2$ of the Islamic Centre:

The only expenditure so far incurred against the estimated amount of $£$ roo on the Library and Reading Room is $\mathcal{E}_{\text {r.6. }}$ -

The solvency of the Islamic Centre Fund depends upon a renewal of the grant by the British Council and the continuance of donations.

J. A Woodhead

28 January $194^{2}$

$\frac{\frac{\text { THE BUILDING OF A MOSQUE IS NOT ONLY THE }}{\text { REALISATION OF THE SAYING OF PROPHET }}}{\frac{\text { MOHAMMAD BUT ALSO THE FULFILMENT }}{\text { OF THE ORDER OF GOD }}}$

Brothers in Islam

It was in 1934 that the JAMIAT-UL-MUSLIMIN was founded in the great Metropolex of London, and under this association has gathered together Muslims and sympathisers from different parts of the world, without distinction of cast, creed or religion, to celebrate such festivals as the Birthday of Prophet Mohammad, A'Ashura, Idan and Friday Prayers. 
It has now been found necessary to erect a Mosque for daily prayers, including a reading room, hostel, free bath for the needy and classes for Islamic culture and education.

So far this work has been carried on by the initiative of the members only, it has been found inevitable that funds should be collected from all Muslims and sympathisers for the complete realisation of this noble cause.

Hon Sec Jamiat-ul-Muslimin

59 Canton Street

London E I4

[Urdu text follows this note]

National Liberal Club

Whitehall Place

SW I

Tel: Whitehall 9871

26 January 1942

Dear Mr Khan

I have been away from London and have just got your letter of 12 January on my return.

I enclose the report of my speech, duly corrected. As my health is uncertain, I will not at present accept an engagement for East London.

Salaams to you and brethren.

Yours sincerely,

Yusuf Ali

\section{Approved at the meeting of the Trustees and Executive Gommittee held on 23 January 1942:}

LONDON MOSQUE FUND

Estimated annual receipts and expenditure: 
Interest on Securities in the hands of Trustees: $\quad \begin{array}{ccc}\mathcal{S} & \mathrm{s} & \mathrm{d}\end{array}$

Interest on Securities in the hands of Trustees: 234. I6. 6

I. Audit Fee

2. Clerical assistance

3. Caretaker

4. Religious Observances and Prayers

I. I. -

6. - - $\quad-$

Id-ul-Fitr £io.IO

Id-ul-Adha $\quad$ EIo.Io

Milud-e-Nabi $\quad$ E 55 .-

5. Al Hadj Hafiz Mohammed-el-Shami

(teacher of the Koran)

6. Annual grant to Islamic Centre

7. Telephone, Electricity and Gas

52. - -

8. Water Rate

(the annual Rate is $\mathrm{f}_{\mathrm{I}} 5$ of which two-thirds

is debited to the Mosque)

36. - - -

30. $\quad-. \quad-$

52. $-. \quad-$

23. - - -

Total:

2IO. I. -

Telephone - The only guide to the yearly expenditure is the bill for the quarter ending 30 September i94I. i.e $\AA^{2.8 .5}$ d. This points to an expenditure of say f, Io, two-thirds of which is debited to the Mosque fund and one-third to the Islamic Centre.

Electricity - Here again the only guide is the bill for the second quarter of I94I/42 i.e. EI.I6. Io. This points to an expenditure of say \&8, twothirds of which is debited to the Mosque and one-third to the Islamic Centre.

Gas - The expenditure is roughly estimated at \&I6 - two-thirds to the Mosque and one-third to the Islamic Centre.

\section{Minutes of the Meeting of the Trustees of the London Mosque Fund held on 15 June 1942 at the India Office}

\section{Present:}

Sir Hassan Suhrawardy

Monsieur H.M. Said

Sir M. Azizul Huque*

On the proposal of Sir Hassan Suhrawardy, seconded by Monsieur H.M. Said, it was resolved that Sir M. Azizul Huque be appointed a Trustee. 


\section{Minutes of the Meeting of the Trustees of the London Mosque Fund and the members of the Executive Committee held on 15 June $194^{2}$ at the India Office}

Present:

Sir Hassan Suhrawardy

Monsieur H.M. Said

Sir M. Azizul Huque

Mr Amir Shah

Mr Sahib Dad Khan

Sir John Woodhead, Hon Treasurer

Colonel Newcombe, Joint Hon. Secretary

Apologies for absence were received from Lord Winterton, Mr Waris Ameer Ali, Mr K. Lebanne, Mr Mahmood R. Zeda and Sir Ernest Hotson.

I. The Minutes of the meeting held on 23January were confirmed.

2. On the proposal of Sir Hassan Suhrawardy, seconded by $\mathrm{Mr}$ S.D. Khan it was resolved that Sir Azizul Huque be elected a member of the Executive Committee.

3. On the proposal of Sir Azizul Huque, seconded by Monsieur H.M. Said, it was resolved that sanction be given to the expenditure of $£ 5$ incurred on entertaining the Indian Pioneer Corps on the occasion of the opening ceremony at the East London Mosque on i August I94I.

4. On the proposal of Sir Azizul Huque, seconded by Monsieur H.M. Said, formal approval was given to the grant of $£ 5^{2}$ to the Islamic Centre during the year ending the 3I March 1942 and the authority was given for a similar grant during the year ending 3 I March i943.

5. On the proposal of Sir Hassan Suhrawardy, seconded by Sir Azizul Huque, formal approval was given to the division in the proportion of 2 to I between the London Mosque Fund 
main account and the $\mathrm{B}$ (Islamic Centre) account of the total recurring expenditure on:

i) Gas

ii) Electricity

iii) Telephone

iv) Water Rate

v) Rates and Taxes

6. On the proposal of Sir M. Azizul Huque, seconded by Monsieur H.M. Said, it was resolved that the audited accounts for a) the London Mosque Fund (main account) and b) the Islamic Centre (B account) be passed.

7. On the proposal of Sir Hassan Suhrawardy, seconded by M.S. Amir Shah, it was resolved that:

a) the Auditors, Messrs. Feasey, Hull \& Feasey, be thanked for their services during the year ending 31 March i942;

b) Messrs. Feasey, Hull \& Feasey be appointed auditors for the year ending 3i March I943.

8. Sanction was accorded to the payment of the Audit Fee of E. I.6.3d for the period ending 3i March 194I.

9. Sanction was accorded to the following expenditure incurred between I January 1942 and 3I March 1942 (both dates inclusive):

\section{LONDON MOSQUE FUND (main account)}

Wages

$£, 28$

Gas, electricity, \& Telephone

Rates and Taxes

Miscellaneous Expenditure

$\begin{array}{rrr}£ 28 & - & - \\ \AA 26 & 9 & 2 \\ £ 3^{2} & \text { I9 } & \text { I0 } \\ \AA 2 & \text { I4 } & 2\end{array}$

ISLAMIC CENTRE (B account)

Wages

$$
£ 23 \quad \text { I2 }
$$

I0. It was reported that the position in regard to rates and taxes (other than the water rate) was as follows:-

a) No. $45^{\circ}$ Commercial Road has not been assessed because it is unoccupied;

b) The ground floor and basement of Nos. 446 and 448 Commercial Road and the building at the rear of Nos. $446 / 448$ 


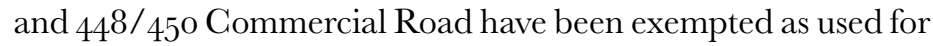
religious purposes;

c) The ist and 2nd floors of Nos. 446 and 448 Commercial Road have been assessed at $£ 80$ gross value per year and $£ 60$ net annual value

d) The rates at present payable work out at $£$ 47.IO.- d a year.

II. It was reported that Sir Ernest Hotson had reluctantly felt compelled to resign from the position of Joint Hon. Secretary. It was resolved that Sir Ernest's resignation be accepted with great regret and that the thanks of the Trustees and the Executive Committee be conveyed to Sir Ernest for his services. Colonel Newcombe very kindly agreed to carry on for the time being as sole Hon Secretary.

I2. Mr Waris Ameer Ali in his letter regretting that he would be unable to be present at today's meeting had put forward certain suggestions for reducing the expenditure so as to ensure that the receipts and expenditure balanced. It was decided that the consideration of these proposals be postponed till a later meeting at which Mr Waris Ameer Ali would be able to be present.

13. The note by Sir Hassan Suhrawardy ${ }^{136}$ in regard to:-

a) the disposal of the balance of the gift of $£$ I50 given by His Majesty, King Faruk I of Egypt on the occasion of the Id-ul-Fitr;

b) the copies of the Holy Quran and prayer caps $^{137}$ given by the Shaikh of the $\mathrm{Al}$ Azhar University, ${ }^{1{ }^{8}}$ His Eminence, the Shaikhul-Maraghi for use at the East London Mosque.

The Trustees and the Members of the Executive Committee desired that Sir Hassan should convey, through the proper channels, their grateful thanks for the very generous gifts of money made by His Majesty, King Faruk and for the copies of the Holy Quran and prayer caps presented to the Mosque by His Eminence, Shaikh-ul-Maraghi.

The Trustees and Members of the Committee concurred in the proposals made by Sir Hassan for the expenditure of the unspent balance of the gift by His Majesty, King Faruk I.

I4. A letter was considered which had been received from the Hon Secretary (Mr S. Khan) of the Islamic Council in Great Britain requesting that the Council be permitted to use the

\footnotetext{
${ }^{136}$ A copy of Sir Hassan Suhrawardy's note was attached as an annexure to these Minutes: see below, pp. 217-218.

${ }^{137}$ Prayer caps, contrary to popular belief, are not worn by all Muslim men during prayers.

${ }^{138} \mathrm{Al}$ Azhar Mosque in Cairo, Egypt, is associated with Al Azhar University, one of the oldest Islamic institutions in the world, established around 97I CE.
} 
room in the Trustees' premises in Commercial Road, now used by the Jamiat-ul-Muslimin under licence from the Trustees and as agents of the Trustees. It was resolved that this matter be postponed till a later meeting and that in the meantime the Islamic Council be asked to supply full information about the aims and objects of the Islamic Council in Great Britain, together with the names of its office bearers and affiliated Societies.

I5. The proceedings terminated with a note of thanks to the Chair.

Confirmed: A Waris H Suhrawardy 20 August 1942

\section{[Sir Hassan Suhrawardy's note, as mentioned above]}

To the Trustees, London Mosque Fund

While at Cairo in October I94I, I had an audience with His Majesty, King Faruk I. His Majesty not only discussed details regarding the big Central London Mosque scheme, of which he is the patron, but he also showed much interest in the small East London Mosque, at the opening ceremony of which, he was graciously pleased to send a message to us. On my representation, His Majesty ordered EI50.0.o from his privy purse to be sent to His Excellency, the Egyptian Ambassador to be spent on the 'Id-ul-Fitr entertainment. The money was to be given to our agent the Jamiat-ul-Muslimin, the names of some of the members of which, I gave to the King's Chamberlain. This was done and I understand the function went off most successfully. His Excellency, Shaikh Hafiz Wahba conducted the prayers and over 800 people were in the congregation, including soldiers from the Indian contingent and the Pioneer Labour Corps.

The Egyptian Ambassador, Hasan Nachat Pasha, whom I have seen on his return to London from Egypt a few weeks ago, I understand has got a certain sum of money unspent with him.

With the concurrence of the Trustees, I would like to approach His Excellency to spend the money in the following manner:

I. In providing and getting microphones installed so that the KHUTBA (sermon) ${ }^{139}$ and TAKBIR (Call to prayer) ${ }^{140}$ may

\footnotetext{
${ }^{139} \mathrm{Also}$ written as khutbah, this is a sermon that the Prophet Muhammad gave regularly at Medina. It is prescribed by all Sunni legal schools at the zuhur (noon) Friday congregation prayers. In addition, similar sermons are delivered at the two annual festivals, Id al-Fitr and Id al-Adha.

${ }^{14^{\circ}}$ Takbir, as distinct from Adhan, is literally the Arabic call 'Allahu Akbar' (God is Great).
} 
be transmitted from the prayer hall to the lecture hall which is also used as an additional congregation hall during the 'Id prayers and other religious celebrations. Any money which may be left over after paying for the microphones and their installation -

2. To be spent in purchasing a number of suitable books which may be presented on behalf of His Majesty, the King of Egypt to the East London Mosque Islamic Culture Centre.

During my stay at Cairo, I also had several discussions with the Shaikh of $\mathrm{Al}$ Azhar University, His Eminence, the Shaikh ul Maraghi, and at my request he was pleased to make a contribution to the East London Mosque of 5 o bound copies of the Holy Quran and of 50 washable caps to be used during prayers. I arranged with the authorities at the British embassy to send them on through Diplomatic channel to London and also arrange for their distribution to the East London Mosque, 446/448 Commercial Road, Er, one half through the Ministry of Information and the other half through the British Council, as both of these organisations have representative members on the Committee of Management of the Islamic Culture Centre of the East London Mosque.

I very much regret to report that I have been informed that some of the copies of the Quran were given to the Imam of Woking Mosque, in Surrey, for distribution. I had correspondence with Dr Arberry suggesting that the copies distributed obviously by mistake should be recalled and distributed to the East London Mosque, as they were specifically given to me for this purpose and forwarded to London by the British Embassy at my request. I also suggested that the copies should be sent to our Honorary Treasurer, Sir John Woodhead, at the India Office, so that they could be put on the inventory as property of the Mosque and then made over to our agents, the Jamiat-ulMuslimin, for use there.

Sir Stephen Gaselee has addressed Sir John Woodhead in connection with this matter, and I hope it will not be long before this matter is satisfactorily settled.

India Office

Whitehall

SWI

8 June 1942 
INDIA OFFICE

Whitehall SWI

27.July i942

The Rt Hon L.S. Amery, P.C., M.P.

Secretary of State for India

I am glad to inform you that, on Thursday 23 instant, we had a meeting of the London Central Mosque (Jamea) Committee at the Egyptian Embassy. This meeting was the first one to be held after the meeting held on Friday 25 July 194I, which you, Lord Moyne and Lord Reith also attended. We were very glad indeed on the successful acquisition of a splendid site in Regents Park with a fine building called the Regent Lodge, which, with some alterations, can be put into use almost immediately as an Islamic Culture Centre and as a Mosque. It is a great achievement, and Hassan Nachat Pasha deserves all credit for his practical imagination.

In this connection, I would like to bring to your notice the fact that the cost will be well under the $f_{\mathrm{I}} \mathrm{OO}, \mathrm{ooo}$ sanctioned by His Majesty's Government. The surplus will be credited back to the Treasury.

As you know, the London Mosque Scheme sponsored by His Highness the Aga Khan and the late Rt Hon Syed Ameer Ali in IgIo, had collected a sum of money, a considerable portion of which has been utilised in purchasing a small property in the East End of London for use as a Mosque and Islamic Culture Centre. This was done in view of the large Muslim population in the East End, and the large numbers of Muslim seamen who in normal times visit the Port of London. This small Mosque and Islamic Culture Centre (at 446/448/450 Commercial Road, EI) was publicly opened by His Excellency the Egyptian Ambassador on I August I94I and was visited by you on 7 August of that year.

On behalf of the Trustees of the London Mosque fund, may I venture to approach you with the request to interest yourself in this matter, and consult the Colonial Secretary and the Foreign Secretary as to whether it would be possible, with the residual money from the grant to the Central Mosque Scheme, to acquire the land contiguous to the present East London Mosque and Islamic Centre (446.448.450 Commercial Road EI).

If this were done, the Trustees of the London Mosque Fund would possess a site on which it would be possible to erect buildings in every way suitable for a Mosque and Islamic Culture Centre after the war.

Yours Sincerely

Hassan Suhrawardy 


\section{Minutes of the Meeting of the Trustees of the London Mosque Fund held on 20 August $194^{2}$ at the India Office}

\section{Present:}

Sir Hassan Suhrawardy

Mr Waris Ameer Ali, C.I.E

Earl Winterton, M.P

With

Sir John Woodhead, Hon Treasurer

Colonel S.F Newcombe, Hon Secretary

I. The minutes of the meeting of the Trustees held on I5June 1942 were read and confirmed.

2. The resignation (vide his letter of I3 June I942) of Mr A Yusuf Ali, C.B.E was recorded. The Trustees placed on record their appreciation of the services rendered by Mr Yusuf Ali.

3. Mr Waris Ameer Ali and Lord Winterton, who were unavoidably absent from last (I5 June I942) meeting, signified their concurrence in the appointment of Khan Bahadur Sir M. Azizul Huque, C.I.E, as a trustee with effect from I5June 1942.

4. The Hon Treasurer reported that the $3 / 2 \%$ India Stock (I93I), to the face value of $£ 2596$.I2.I I, held by the Trustees had been sold and that in the place of this stock the Trustees had purchased

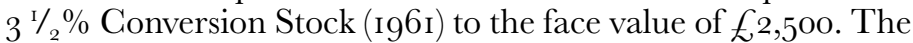
details of the transactions were as follows:

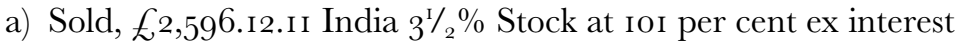
July 1942

$$
£ 2,624.8 \mathrm{~d}
$$

Less stamp 6s od and commission $£_{\text {I.I. }} 2.5 \mathrm{~d}$

$$
\text { £.r.18.5d }
$$

$£ 2,622.6 .3 \mathrm{~d}$

b) Purchased, $f^{2}, 500$ Conversion $3 \frac{1}{2} \%$ Stock at $1081 / 4$ cum interest October 1942

$$
\text { £2,706.5.od }
$$

Plus stamp 6s od and commission $£ 6.5 .00$ 
The difference between the sale proceeds of the India Stock and the cost of Conversion Stock will be met from the current funds of the Trust Fund.

5. Sir Hassan Suhrawardy explained the position, so far as information is available, in regard to the grant of $f_{1} \mathrm{IOO}, \mathrm{OOO}$ which had been provided by His Majesty's Government for the purchase of a site in Central London for a Mosque, and said that although it was not yet certain that there would be a saving out of this grant, he had thought it desirable to address the Secretary of State for India at the earliest possible moment with a view to urging that any balance should be utilised in acquiring the land contiguous to the East London Mosque so that the Trustees would be in possession of a site in every way suitable for the erection of a Mosque (a copy of the letter forms an annexure to these minutes). It was decided that:

a) the action taken by Sir Hassan Suhrawardy be confirmed;

b) steps should be taken to explain to the Press, informally and in so far as appeared desirable, the position in regard to

i) the Mosque which is to be built on the site acquired at the expense of His Majesty's Government in Regents Park; and

ii) the East London Mosque

The points which it is desirable to bring out are that the Moslem population, particularly in peace time, in the East end of London is considerable, that the proposed Mosque in Regents Park cannot meet the need of this community for a regular place of worship, that this need is met by the East London Mosque, and that the Trustees of this Mosque are in need of funds for the purpose of enlarging the site on which the present "temporary" Mosque is situated in order to enable them to undertake the erection of a Mosque suitable in every way to the religious needs of the Moslem Community in the East End.

6. The position of the Jamiat-ul-Muslimin in relation to the East London Mosque and the Trustees of the London Mosque Fund was discussed. ${ }^{14}$ It was pointed out that according to

\footnotetext{
${ }^{141}$ At the inauguration of the East London Mosque, it was already apparent that it would be an arena in which Indian Muslim politics would figure. For instance, British intelligence reported that a Pakistan Movement pamphlet was freely circulated there. Shah Abdul Majid Qureshi, reminiscing later, pointed to the political divisions between some of the Trustees and others belonging to Jamiat-ul-Muslimin: 'In my early days I used to be a Congressman. Sir Hassan Suhrawardy was a pious Muslim from a learned family. During the war [...] we were celebrating our Eid prayers at the East London Mosque, under the leadership of Suhrawardy. At the end he said in a loud voice, "Oh Allah, give victory to the Allies!"
} 
the arrangement, to which the Jamiat agreed, made in I94I, the Jamiat-ul-Muslimin was appointed as the "Agents" of the Trustees in regard to the carrying out of the religious observances at the Mosque and works in connection with the Islamic Culture Centre. (A copy of the letter by which the Trustees appointed the Jamiat as agents is attached to these minutes). Lately, however, there have been indications that the Jamiat was failing to recognise the "Agency" position. It was agreed that it should be explained to the Jamiat that they were acting in regard to the affairs of the Mosque and the Islamic Culture Centre purely as agents of the Trustees and in particular that the room in the Mosque building which had been placed at their disposal should not be used for any purpose other than connected with the affairs of the Mosque and the Islamic Culture Centre.

7. It was also considered that the Jamiat-ul-Muslimin should make over to the Trustees any funds which they may collect towards the building of the Mosque.

8. The meeting terminated with a vote of thanks to the Chair.

Confirmed Hassan Suhrawardy 20 August 1943

\section{Annexure to Minutes of the meeting held on 20 August 1942}

20 May I94I

Dear Sir

$$
\underline{446 \text { and } 448 \text { Commercial Road }}
$$

We have converted the two houses above mentioned into one building to be used for religious purposes and (subject to any necessary consent being obtained) are willing to appoint you our agent for such purposes.

Congress Muslims in the mosque protested after the prayers [...] "Why did you pray for the British?" They made him cry, poor fellow [...] Some of us being of a reasonable mind said [...] but victory of Allies means victory of the Muslims' (Caroline Adams, Across Seven Seas and Thirteen Rivers (London, I986), p. I62). 
I. As such agent:

i) You are to be responsible for arranging in accordance with the directions which we may from time to time give to you the carrying out in the above premises of prayers, religious ceremonies and works in connection with the Islamic Culture Centre and also funeral and requiem prayers.

ii) You are to make good any damage which may be done to the said premises and the furniture and fittings therein by any person or persons in your employ such damage to be made good at your own expense.

iii) You are to use your best endeavours to prevent any damage being done to the said premises and the furniture and fittings therein from any cause or by any person or persons (other than your own employees) who may visit the premises.

iv) You are to see that all prayers, religious ceremonies and works are carried out with all due solemnity and that the resident caretaker and other persons employed by us carry out their duties in a satisfactory manner and that the said premises are used only for the religious purposes aforesaid and for no other purpose and in particular you are not to allow any meeting or speeches of a political nature to be held or to take place on any of the premises.

v) You are to carry out on premises other than the above premises such of your aims and objects set forth in your rules and regulations for the time being which are not of a religious character.

vi) Any persons employed by you are not to be regarded as our servants but are to be your servants and are to be paid by you accordingly.

vii) You are to keep us and our registered proprietors for the time being of the above premises and our Trustees and Members of our executive Committee for the time being indemnified from all claims and demands which may be made against us or them or any of them by reason of any wrongful or unpermitted user of the said premises.

2. In consideration of the foregoing you are to have the use of one room (to be selected by us) in the said premises to be used by you free of rent as an office in connection with the religious purposes aforesaid and also in connection with any other religious purposes in which you are concerned and of which we approve together with the use of the telephone free 
of charge for official calls in relation to those religious purposes for which you are acting as our agent and you are also to be at liberty on paying for calls to use such telephone in relation to any other religious purposes with which you are concerned and of which we approve.

3. This document is not to be construed in any way as conferring upon you any estate or interest whatsoever in the said premises but is to be regarded as a mere licence only.

4. The agency hereby created is not to be transferrable by you and is to be terminable at any time by either you or us on giving to the other one week's previous notice in writing in that behalf. ${ }^{14^{2}}$

Yours faithfully

(Sd) E. Hotson

Sir Ernest Hotson

Hon Secretary

LONDON MOSQUE FUND

\section{$\underline{\text { Jamiat-ul-Muslimin }}$}

We, the undersigned the Chairman, the Hon Treasurer and the Hon General Secretary of the Jamiat-ul-Muslimin hereby agree to the above on behalf of the Jamiat-ul-Muslimin and (pursuant to its rules and regulations) hereby sign this document on its behalf.

(Sd) Gholam Muhammad ${ }^{143}$

Hon President
(Sd) Ahmeddin Qureshi ${ }^{144}$

Hon Treasurer
(Sd) S. Khan ${ }^{\mathrm{I} 5}$

Hon Secretary

\footnotetext{
${ }^{142}$ These conditions appear to represent a tightening up on previous, lax, arrangements.

${ }^{143} \mathrm{~A}$ silk merchant in London's East End, married to a British white woman. See BL, IOR, P\&J (S)/7I6, fo. 2, report of the Metropolitan Police (Special Branch), I7 August 1938.

${ }^{144}$ Born in 1910 , he was a silk merchant from Jullandur, Punjab, living in Aldgate, London. Ibid.

${ }^{145}$ This is the same Sahibdad Khan who was a leading member of the Jamiat-ul-Muslimin. See biographical note in Appendix I and note in Appendix III.
} 
Minutes of the Meeting of the Executive Committee held on Wednesday 26 August 1942

Present:

Sir Hassan Suhrawardy, Chairman

A. Yusuf Ali Esq

M. R. Zada Esq

Sahib Dad Khan Esq

S. Amir Shah Esq

K. Lebbane Esq

Hatim Attari Esq*

Dr Arberry

A Steel, Esq (Representing the British Council)

With Sir John Woodhead, Hon Treasurer

Colonel Newcombe, Hon Secretary

I. The minutes of the meeting held on I5June I942 were read and confirmed.

2. On the proposal of Sir Hassan Suhrawardy, seconded by Mr Yusuf Ali, Mr Hatim Attari of 4I Berkeley Square, WI was elected a member of the Executive Committee.

3. On the proposal of Mr Waris Ameer seconded by Mr R. Zada, it was decided that

a) the Managing Committee appointed to deal with the affairs of the East London Mosque and the Islamic Culture Centre, vide meeting of I4 August I94I and 23 January I942, be dissolved. (Note: The effect of this is that there is no Committee other than the Executive Committee which is provided for by the Trust Deed).

b) As provided for in the letter of 20 May I94I from the Trustees to the Jamiat-ul-Muslimin, to the terms of which the Jamiatul-Muslimin agreed, the Jamiat-ul-Muslimin of Great Britain in its capacity as representing the Congregation of the East London Mosque and the Muslim population of the East End of London, be entrusted with the duty of administering, as the agents of and subject to the general direction and control of the Executive Committee and the Trustees, the affairs of the East London Mosque and the Islamic Culture Centre. 
4. With reference to item I4 of the meeting held on I5 June I942, Mr Sahib Dad Khan informed the meeting that the Islamic Council in Great Britain had made other arrangements and did not now wish to be given permission to use the room in the Mosque premises for office purposes. The Trustees would be informed in writing accordingly in the near future.

5. A long discussion took place in regard to the items of expenditure which would be met directly by the Trustees and those for which the Jamiat-ul-Muslimin would accept responsibility, subject to any financial assistance the Trustees might be able to give. No decision had been reached on this matter when the meeting was adjourned to a subsequent date.

H Suhrawardy 7 October $194^{2}$

\section{Minutes of the Meeting of the Executive Committee of the} London Mosque Fund, held on Wednesday 7 October 1942

\section{Present:}

Sir Hassan Suhrawardy (Chairman)

A. Yusuf Ali, Esq, C.B.E., I.C.S., (Rtd)

Sir Azizul Haque, C.I.E

Waris Ameer Ali, Esq, C.I.E., I.C.S

Sahibdad Khan, Esq

Colonel Stewart F. Newcombe, D.S.O (Hon Secretary)

Sir John Woodhead, K.C.S.I (Hon Treasurer)

Apologies for absence were received from M.R. Zada, Esq, Hatim Attari, Esq, and A. Steele, Esq (of the British Council).

I. The minutes of the meeting held on 26 August 1942 were read and confirmed.

2. The subject referred to in paragraph 5 of the minutes of the meeting held on 26 August was further discussed. The following decisions were reached with the concurrence of all present: -

I. The Jamiat-ul-Muslimin, as provided in the letter of 20 May I94I from the Trustees to the Jamiat-ul-Muslimin, is entrusted with the duty of administering, as agents of and subject to the general direction and control of the Executive Committee and 
The Trustees, the affairs to the East London Mosque and the Islamic Culture Centre.

II. The following items of expenditure will be met by the Trustees and the Executive Committee direct:

a) the Mosque:

I. Clerical Assistance

2. Water Rates (two thirds of $\mathcal{f}_{77}$ )

3. Rates (two thirds of $£ 47$.Io) say

4. Audit Fee

5. Cost of annual repairs, external and internal, including repairs at five and seven years intervals

6. Insurance and other miscellaneous expenditure on account of postage etc.

b) The Culture Centre:

I. Water Rates (one third of $£_{1} 17$ )

2. Rates (one third of $£ 47$.Io) say
Estimated Expenditure

£6. -.-

£iI. 6.8

$£ 32$

E r. r.-

£65.---

Ei5. -.-

f. 5. 13.4

£i5.IO.-

NOTE: Out of the amount of $£ 65$ shown under 5 above $£_{15}$ will be at the disposal of the Jamiat-ul-Muslimin for internal repairs.

III. Subject to the grants referred to in V below the Jamiat-ulMuslimin will be responsible for all other expenditure incurred in connection with the Mosque and the Islamic Culture Centre.

IV. The power of appointing, dismissing and fixing the salaries of the caretaker of the property in Commercial Road and the teacher of the 'Kuran at the Mosque will lie with the Executive Committee. ${ }^{14^{6}}$ In these matters the Executive Committee will consult the Jamiat-ul-Muslimin and in reaching their decisions will take into consideration the views expressed by the Jamiatul-Muslimin.

V. For the year beginning I December I942 and ending 30 November 1943 the Executive Committee will make a grant of $£_{\mathrm{IO}} \mathrm{O} 2$ to the Jamiat-ul-Muslimin toward the expenditure referred to in III above; out of the $£_{1}$ IO2 the sum of $£ 52$ is earmarked for expenditure on the Islamic Culture Centre. This grant will be made quarterly in advance, f25.Io.- on I

\footnotetext{
${ }^{146}$ In effect this allowed the Executive Committee to keep control of the teaching taking place at the mosque.
} 
December, £25.IO.- on I March, £25. IO.- on I June and £25.I0.on I September, I943. At the end of each quarter the Jamiat-ulMuslimin will supply the Executive Committee with a statement of expenditure incurred during the quarter, showing separately the expenditure on the Mosque and Islamic Culture Centre.

3. After Discussion Mr Waris Ameer Ali agreed not to press the points made in his letter of I2 September to Sir Hassan Suhrawardy.

4. The Executive Committee thanked the Jamiat-ul-Muslimin for sending them a copy of their Annual Report for the year I94I42. ${ }^{147}$ In discussion it was pointed out that the form of the report and account attached thereto might lead to misunderstanding because it did not specifically bring out that, in regard to the Mosque and the Islamic Culture Centre the Jamiat-ulMuslimin was acting as agents to the Trustees and the Executive Committee, and in regard to the burial of indigent Muslims as agents of the Committee of the Indigent Muslim Burial Fund. It was also pointed out that it was not correct for the Jamiat to describe $44^{8}$ Commercial Road as their Headquarters Offices, for it was made clear in the Trustees letter of 20 May I94I, vide paragraph I (v) and 2, that the room which had been placed at the disposal of the Jamiat free of rent was for the purposes of carrying on their work in connection with the Mosque and the Culture Centre as agents of the Trustees and for any other religious work with which the Jamiat are concerned and of which the Trustees have approved..$^{1{ }^{8}}$

5. The meeting closed with a vote of thanks to the Chairman.

Confirmed: H Suhrawardy 7 April 1943

\section{Minutes of the Meeting of the Executive Committee of the London Mosque Fund held on Wednesday 7 April 1943}

Present:

Sir Hassan Shurawardy (Chairman)

Waris Ameer Ali, Esq C.I.E., I.C.S. (Rtd)

\footnotetext{
${ }^{147}$ Copy of report is available at the ELM Archives.

${ }^{14}{ }^{8}$ From this note, it would appear that the Executive Committee was anxious that the Jamiat-ul-Muslimin might be engaged in activities that fell outside its remit as the agent of the Trust.
} 
Sahebdad Khan, Esq

Said Amir Shah, Esq

Hatim Attari Esq

Anthony Steel, Esq, of the British Council

Syed Mahomed Sayeed ullah, Esq

Colonel Steward F. Newcombe D.S.C

Sir John Woodhead

Apologies for absence were recorded from Sir Azizul Huque.

I. The Minutes of the meeting held on 7 October I942 were read and subject to the correction of an arithmetical error, were confirmed.

2. On the proposal of Sir Hassan Suhrawardy, seconded by $\mathrm{Mr}$ Sahebdad Khan, Mr Syed Md. Sayeedullah was elected a member of the Executive Committee.

3. The appointment of Mr Ali Basha as Caretaker and teacher of the Koran was confirmed.

4. Considered the following bills by Messrs. Turner \& Cooper Ltd for repairs to the property in Commercial Road:

Ordinary Repairs:

450 Commercial Road

446 \&448 Commercial Road

£44.3.10

\& $32.15 \cdot 7$

Sub total

£ $76.19 \cdot 5$

War Damage Repairs: 446 \&448 Commercial Road

£ $80.5 \cdot 3$

TOTAL

£i $57 \cdot 4.8$

It was decided that payments be made in accordance with the advice of the Architect, Mr MacDonald.

5. The letter dated Io March I943 from the British Council (copy annexed) in connection with the Islamic Culture Centre was considered. It was agreed that the Committee would not be justified in asking the British Council to renew the grant of $£ 75$.

Mr Steel said that as regards the grant of $£ 75$ already made the Council would be pleased if they could be supplied with an account showing how it had been spent. He explained that while the Council did not propose to renew the grant of $£ 75$ they would be glad to continue to assist the work of the Culture Centre by supplying books and newspapers and by paying the salary of Mr Hussein. He suggested that a list of the books required should be prepared and forwarded 
to the Council. The Council would then decide what assistance they could give either by supplying the books or by meeting the cost thereof. As regards newspapers he said the Council would continue to supply the Daily Telegraph and the Sunday Times.

There was some discussion as regards visits to factories. The view was that visits to food factories would be welcomed. Mr Steel though this could be arranged.

The Committee desired to take this opportunity of recording their appreciation of the assistance the British Council had given to the Culture Centre. They were very grateful for Mr Steel's assurance that in spite of the difficulties experienced in the past the Council were desirous of continuing to assist the Centre.

6. The Hon Treasurer explained the financial position. He said the accounts for the year ending 3i March had not yet been finally prepared and audited and so the figures he would now give were subject to correction.

\section{$\underline{\text { Mosque Accounts }}$}

(I) Receipts. Dividends £233. 2.10

Donations $\quad \mathcal{E}$ 80.7.II (including a grant of $\mathcal{f}^{20}$ by

H. $\mathrm{H}$ the Aga Khan for the year $\left.1943^{-4}\right)$

$\begin{array}{ll}\text { Transfer from "B" } & \\ \text { Account } & £ 30.6 .6 \\ \text { Total: } & £ 343.17 .3\end{array}$

(2) Expenditure exclusive of the grant of $£ 55$ for the Culture Centre - this grant has not been made in $194^{2-} 3$. E. 34 I.18. 6

Culture Centre ("B" Account)
(I) Receipts
£ I0.18. о
(2) Expenditure including
transfers to Mosque Account
£ir4. о. o

The Hon Treasurer pointed out that the expenditure of $£ 34$ I odd included nothing on account of repairs. There would be considerable expenditure of this nature in 1943/4. The excess of expenditure over receipts in the Culture Centre account had been net out of the previous year's surplus. 
7. It was decided that in view of the expressed desire of Colonel Newcombe to resign, his resignation be accepted. The Committee placed on record their great appreciation of all that Colonel Newcombe had done for the Mosque and the Culture Centre. They were deeply grateful to him for the assistance he had so willingly given and hoped that he would remain a member of the Executive Committee.

On the proposal of Sir Hassan Suhrawardy, seconded by Mr Waris Ameer Ali, it was decided that Mr Hatim Attari and Mr Sayeedullah (of 46 Kingswood Court, West End Lane, NW6) be elected Joint Hon Secretaries in place of Sir Ernest Hotson and Colonel Newcombe. (Note: Sir Ernest Hotson's retirement was noted in the Minutes of the Meeting of I5 June I942)

8. The meeting terminated with a vote of thanks to the Chair.

Confirmed: H Suhrawardy 2 July 1943

THE BRITISH COUNCIL 3 HANOVER STREET LONDON WI

Io March I943

\section{Dear Sir Hassan}

I am very glad to hear from Miss Whitehorn that the long delayed visit to the margarine factory by Moslems from the Islamic Cultural Centre is really going to take place today. As, however, this is, I believe, only the second event which we have been able to arrange for the Islamic Centre during the whole winter in view of their difficulties over finding a caretaker, and, I am afraid I must add, their somewhat non-co-operative attitude, I am in some doubt whether the renewal of our $\mathcal{E} 75$ a year grant at this Centre and the supply of daily papers etc., which it seems to me are seldom read, are really justified.

I have had some discussion with Colonel Newcombe on this subject, and he is inclined to agree with me that before the $£ .75$ grant is renewed during the coming financial year, the British Council should receive an audited statement of what has been done with the money. If, as I suspect, there is a considerable balance on the $1942 / 3$ grant, we should be prepared to allocate this towards the cost of certain religious books, toward which Mr Khan asked me for a contribution the last time I was in the Centre, but Colonel Newcombe agrees with me that 
it would not be proper for the British Council to continue their grant into the future simply for this purpose. We shall of course continue to pay the salary of Mr Hussein on the same basis as before, so that should be some help with the religious teaching, which is, I know, an important part of his work.

Perhaps you would be kind enough to let us know the views of your Committee on the subject of the grant and proposed purchase of religious books, and I should also be grateful if you could obtain the audited statement for $1942^{-}-3$.

Yours Sincerely

(Sd) Anthony Steel

London and Eastern

Regional Officer

Sir Hassan Suhrawardy C.B.E

India Office

Minutes of the Meeting of the Executive Committee of the London Mosque Fund, held at India House on Friday 2 July 1943 at I .30 p.m

Present:

Sir Hassan Suhrawardy (Chairman)

Sir John Woodhead (Treasurer)

Colonel Stewart Newcombe

Mr Waris Ameer Ali

Mr Yusuf Ali

Mr Anthony Steel

Mr Kemal Lebbane

Mr Hatim Attari ) Joint Secretaries

Mr S.M Sayeedulla )

Absent:

Sir Aziz-ul-Haque

Mr Zada

Both being out of the Country. 
I. The Minutes of the last meeting held on 7 April were read. $\mathrm{Mr}$ Steel made certain observations in regard to the salary of Mr Hussein and the secretaries were instructed to enquire the total amount of salary Mr Hussein is drawing, by whom paid and a list of subjects he is teaching. Mr Steel informed the meeting that the British Council would be agreeable to continue to pay the salary and also arrange to supply books, journals and periodicals required for the Islamic Centre, on receipt by them of the details. Mr Steel further agreed to arrange excursions on receipt of application from the Islamic Centre. The Minutes of the meeting were then confirmed.

2. The Chairman read to the meeting the letter dated I5 April 1943 received from Jamiat-ul-Muslimin in the matter of the resignations of Mr Sahib Dad Khan and Mr Said Amir Shah, and after discussion it was decided that the consideration of letters of resignation and the letter from Jamiat-ul-Muslimin be postponed. ${ }^{149}$ In the meantime, the Committee authorised Sir Hassan Suhrawardy, Mr K Lebbane and Mr Yusuf Ali to interview the officials of Jamiat-ul-Muslimin with a view to ascertain their views as regards the continuity of their acting as agents of the London Mosque Fund for managing the East London Mosque, and their attitude towards trustees and officials of the Moslem Mosque Fund. The committee felt it desirable that the consideration of the postponed items should not be very long delayed, and accordingly fixed a meeting for Wednesday 2 I July at 3 o'clock to hear from Sir Hassan Suhrawardy, Mr Yusuf Ali and Mr K Lebbane the report of their interviews with the Jamiat-ul-Muslimin, which they hoped to conclude before the date of the meeting.

3. Mr S.M Sayeedeilla's letter to the Chairman and correspondence arising out of it was read by the Chairman and the committee appreciated Mr Sayeedeilla's observations and his promptness in reporting the matter to the Chairman.

4. The lay-out of the Memorial tablet proposed to be put in the East London Mosque was considered by the meeting, and after discussion as to the usefulness of the names of the trustees being embodied on

\footnotetext{
${ }^{149}$ According to an extract from a Metropolitan Police Report of 14 October 1943 (BL, IOR, $\mathrm{L} / \mathrm{P} \& \mathrm{~J} / \mathrm{I} 2 / 468$, fo. 267), 'a dispute, which threatens to precipitate a crisis among Muslims in the East End of London, has arisen between the Board of Trustees and Executive Committee of the London Mosque Fund and the local Muslim association, the Jamiat-ul-Muslimin, over the administration of the affairs of the East London Mosque, 446/450 Commercial Road, E.I'. This extract summarizes and contextualizes the development of the dispute, examining how the opposing sides managed it (ibid., fos 268-272). For more information, see Appendix III.
} 
the Tablet, further consideration of this matter was postponed until the next meeting.

5. Sir John Woodhead informed the meeting that the auditors were not able to complete the accounts, and the consideration of finance was postponed for the next meeting.

6. It was resolved that the Chairman should write to Sir Aziz-ulHaque and Mr Zada thanking them for their useful services to the committee during their membership and requesting them to tender their resignations in view of their departure from the country.

7. The meeting terminated with a vote of thanks to the Chairman.

Confirmed: 2I July i943

\section{Minutes of the Adjourned Meeting of the Executive Committee of the London Mosque Fund, held at the India Office on Wednesday 2 I July 1943}

Present:

Sir Hassan Suhrawardy (Chairman)

Mr Yusuf Ali

Colonel S.F. Newcombe

Mr Hatim Attari ) Joint Hon Secretaries

Mr S.M Sayeedulla)

Sir John Woodhead Hon Treasurer

I. The Report of the sub-committee appointed to interview the officials of Jamiat-ul-Muslimin was read to the committee and is recorded herewith.

2. The Executive Committee considered the Report and resolved to forward a copy of the Report to the trustees of the London Mosque Fund for their consideration and deferred any further action on the Report until the trustees' decision.

3. It was resolved that the resignations of Sahebdad Khan and $\mathrm{Mr}$ S.A. Shah as members of the Executive Committee be recorded. It was further resolved that the letter of Jamiat-ul-Muslimin dated I5 April I943, arising out of the above resignations be also recorded for the present. 
4. Sir Hassan Suhrawardy reported that the sub-committee appointed to consider the Memorial Tablet for the East London Mosque has decided upon the text of this both in English and Arabic, as per both proofs submitted, which are recorded herewith.

5. The Treasurer submitted the draft balance sheets of the London Mosque Fund and Islamic Culture Centre, which showed a combined deficit of over $£$ I20. The income from the investment showed as $£ 233$.

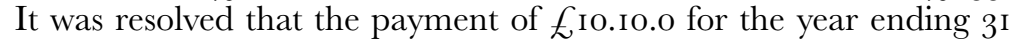
March I942 and $£ 55.5$.o for the year ending 3I March I943 to Messrs. Feasey, Hull \& Feasey, the auditors, be approved.

6. The meeting terminated with a vote of thanks to the Chairman.

Confirmed: H Suhrawardy 3I August 1943

\section{Minutes of the Meeting of the Trustees of the London Mosque Fund held on 20 August 1943}

Present:

Sir Hassan Suhrawardy (in the Chair)

Lord Winterton

Monsieur H.M. Said

Mr Waris Ameer Ali

With

Sir John Woodhead, Hon Treasurer

I. The minutes of the meeting held on 20 August 1942 were confirmed.

2. The Trustees had heard with deep regret of the sudden death of Mrs Ameer Ali, ${ }^{150}$ the wife of their colleague Mr Waris Ameer Ali. The Trustees conveyed to Mr Waris Ameer Ali their deepest sympathy in his bereavement.

3. On the proposal of Lord Winterton, seconded by Monsieur H.M. Said, the audited accounts for the year ended the 3I March I943 were approved.

\footnotetext{
${ }^{150}$ Waris Ameer Ali’s wife, Anne Marguerite, died on I4 July i943. Her funeral was held in Holy Trinity Church, Prince Consort Road, London SW7. See The Times, I6 July I 943.
} 
4. On the proposal of Mr Waris Ameer Ali, seconded by Sir Hassan Suhrawardy, a vote of thanks to the Auditors, Messrs. Feasey, Hull \& Feasey, for their services during the year ending 3I March 1943 was passed. Messrs. Feasey, Hull \& Feasey were appointed auditors for the year ending 3i March i944.

5. It was decided that His Excellency Sheik Hafiz Wahba ${ }^{151}$ be invited to become a Trustee in place of Khan Bahadur Sir M. Azizul Huque who had returned to India.

6. Sir Hassan Surhawardy reported (vide Memorandum attached) that he had received a donation of $\mathcal{E}_{\mathrm{I}}$, ooo from His Highness the Nawab[...] of Bhawalpur [handwriting unclear here] towards the funds of the London Mosque. The Trustees placed on record their joint appreciation of the generous gift of His Highness and there and then signed an airgraph conveying to His Highness their most grateful thanks to Sir Hassan Suhrawardy who had been instrumental in obtaining this handsome donation.

7. It was resolved that the sum of $f_{\mathrm{I}}, \mathrm{Ooo}$ received as a donation from His Highness the Nawab[...] of Bhawalpur should be invested in Savings Bonds, 3\%, I96o-70. The Hon Treasurer was instructed to take steps accordingly.

8. The matters referred to in the annexed note were considered fully. On the proposal of Lord Winterton, seconded by Mr Waris Ameer Ali, it was decided

a) that the investments should be in the names of the Trustees with the exception of His Highness the Aga Khan - this decision was reached because it was within the recollection of some Trustees that in view of the fact that he is often away from the United

\footnotetext{
${ }^{151}$ Sheikh Hafiz Wahba (1889-1967), a scholar of the Al-Azhar University of Cairo, was a close associate of Ibn Saud, the king of Hejaz and Nejd, who appointed him as the Governor of Mecca in I925. In November 1930, he presented his credentials as the first Minister to represent his country at the Court of St James's. Later he was appointed Saudi Arabia's ambassador in London. Well versed in the Islamic science, he became a leading and respected member of the capital's Muslim community. He was invited to lead prayers at annual Islamic festivals at the Woking Mosque (The Times, 28 December 1935); he was a member of the committee of influential Muslims set up to plan the establishment of a mosque in London during the Second World War (The Times, I4 November I940); and he gave the khutba (sermon) and led the juma (Friday congregational prayer) at the opening of the East London Mosque on I August I94I (The Times, 2 August I94I). He died in Rome in I967. For more biographical details, see The Times, 25 November 1967.
} 
Kingdom His Highness the Agha Khan did not desire that the investments should be registered in his name.

b) that steps be taken to place the appointment of the Trustees on a strictly proper legal footing by the execution of the deed as settled by Counsel.

9. The Trustees considered the report (vide annexure to these minutes) of the Sub-Committee of the Executive Committee of the London Mosque Fund on the working of the arrangement by which the Jamiatul-Muslimin was appointed in July I94I as the agents of the Trustees for the management of the Mosque and the Islamic Culture Centre. This report had been referred to them by the Executive Committee. The Trustees decided that the agreement should be terminated. They were of opinion that it is not necessary under any Islamic obligations to appoint an association as agents for managing the religious functions connected with the Mosque. At the same time they desired to make it quite clear that the Mosque is open to all Muslims for worship during the appointed hours and that if the Muslim Association or any other body or person desired to arrange a function after 'Id' prayers or the Prophet's Birthday celebrations, they would be very glad to give permission, if timely application is made. They hoped that the Muslim congregation, who would use the Mosque and the premises, would continue to take the interest which is expected from them as Muslims.

Io. The meeting ended with a vote of thanks to the Chair.

Confirmed: Suhrawardy 8 October 1943

\section{Minutes of the Meeting of the Executive Committee of the London Mosque Fund, held at the India Office on Tuesday 31 August 1943 at 3.30}

\section{Present:}

Sir Hassan Suhrawardy (Chairman)

Mr Waris Ameer Ali

Mr Yusuf Ali

Mr Hatim Attari

Mr S.M Sayeedulla ) Joint Hon Secretaries

Sir John Woodhead ) 
I. The minutes of the meeting held on 3I July i943 were read and confirmed.

2. With reference to Item 2 of the meeting of 2I July, the committee was informed of the decision of the Trustees, which is as follows:-

"The Trustees considered the report (vide annexure to these minutes) of the Sub-Committee of the Executive Committee of the London Mosque Fund on the working of the arrangement by which the Jamiatul-Muslimin was appointed in July I94I as the agents of the Trustees for the management of the Mosque and the Islamic Culture Centre. This report had been referred to them by the Executive Committee. The Trustees decided that the agreement should be terminated. ${ }^{15^{2}}$ They were of opinion that it is not necessary under any Islamic obligations to appoint an association as agents for managing the religious functions connected with the Mosque. At the same time they desired to make it quite clear that the Mosque is open to all Muslims for worship during the appointed hours and that if the Muslim Association or any other body or person desired to arrange a function after 'Id' prayers or the Prophet's Birthday celebrations, they would be very glad to give permission, if timely application is made. They hoped that the Muslim congregation who would use the Mosque and the premises, would continue to take the interest which is expected from them as Muslims."

To give effect to the above decision, the joint Hon Secretaries were asked to serve notice on the Jamiat-ul-Muslimin as follows:

"Under the terms of our Agreement, notice is hereby given cancelling the appointment of Jamiat-ul-Muslimin, the Muslim Association, as agents of the Trustees for managing the religious ceremonies and other duties connected with the East London Mosque."

The Trustees have decided that it is not necessary under any Islamic obligations to appoint an Association as an agent for managing the Religious functions connected with the Mosque. They are desirous of making it quite clear that the Mosque is open to all Muslims for worship during appointed hours. If timely application is made, the Trustees will be very glad to give permission to the

\footnotetext{
${ }^{152}$ According to British intelligence (BL, IOR, L/P\&J/I2/468, fo. 83), the Jamiat-ulMuslimin rejected the notice of termination 'as it was contrary to the word and spirit of the Koran'. For more information on this dispute, see Appendix III.
} 
Muslim Association or any other body or person who would like to arrange an entertainment of 'Id prayers, the Prophet's Birthday celebrations, Muharram, or on any such occasion when in the interest of the Mosque or of any spiritual and religious needs, a meeting or celebration could be appropriately held in the Mosque premises.

It is hoped that the Muslim congregation who would use the Mosque and the premises will continue to take interest which is expected from them as Muslims.

This notice is given with effect from Friday, 3 September 1943, and the seven days required by the Agreement will expire on io September I943.

The Hon Secretary was asked to send for Mr Ali Basha, the caretaker, to see about his salary and insurance book, and the inventory of the Mosque furniture.

3. The letter of resignation of Mr Sahebdad Khan and Mr S.A Shah has already been recorded and as they were representing the Jamiat-ul-Muslimin, and it has been decided to serve them with notice of termination of their agency, there is no reason to ask the Jamiat to send the names of members to fill up the vacancies caused by the resignation of Mr S.A. Shah and Mr Sahebdad Khan.

4. The Hon Treasurer explained the financial position set out in Item 5 of the Minutes of the meeting on 2r July i943, and it was resolved that every effort should be made to reduce expenditure under different items.

5. Sir Hassan Suhrawardy reported that he has the consent of $\mathrm{Mr}$ Shaikh Abdul Hamid that if elected, he will serve as a member of the Committee. It was resolved, on the proposal of Sir Hassan and seconded by Mr Waris Ameer Ali, that Mr Shaikh Abdul Hamid should be elected as a member of the Executive Committee.

6. The meeting terminated with a vote of thanks to the Chairman.

Approved at the meeting of the Trustees and Executive Committee held on 23 January I942:

\section{LONDON MOSQUE FUND}

Estimated annual receipts and expenditure:- 
$\begin{array}{lllll}\mathcal{L} & \mathrm{s} & \mathrm{d} \\ \text { Interest on Securities in the hands of Trustees: } & 234 . & \text { I6. }\end{array}$

I. Audit Fee

2. Clerical assistance

3. Caretaker

4. Religious Observances and Prayers

\begin{tabular}{|c|c|}
\hline Id-ul-Fitr & EIo.Io \\
\hline Id-ul-Adha & £io.io \\
\hline Milud-e-Nabi & $\ell^{1} 5 .^{-}$ \\
\hline
\end{tabular}

5. Al Hadj Hafiz Mohammed-el-Shami

(teacher of the Koran)

6. Annual grant to Islamic Centre

7. Telephone, Electricity and Gas

8. Water Rate

(the annual Rate is $\mathcal{E}_{\mathrm{I}} 5$ of which two-thirds is

is debited to the Mosque)

Total:

$\begin{array}{rrr}\text { I. } & \text { I. } & - \\ 6 . & -. & - \\ 52 . & -. & -\end{array}$

$\begin{array}{lll}36 . & -. & - \\ 30 . & -. & - \\ 52 . & -. & - \\ 23 . & -. & - \\ \text { IO. } & -. & - \\ & & \\ 2 \text { IO. } & \text { I. } & -\end{array}$

Telephone - The only guide to the yearly expenditure is the bill for the quarter ending 30 September i94I. i.e $\AA_{2.8 .5} \mathrm{~d}$. This points to an expenditure of say $f_{\mathrm{IO}}$, two-thirds of which is debited to the Mosque fund and one-third to the Islamic Centre.

Electricity - Here again the only guide is the bill for the second quarter of I94I/42 i.e. EI.I6. Io. This points to an expenditure of say $\AA^{8}$, twothirds of which is debited to the Mosque and one-third to the Islamic Centre.

Gas - The expenditure is roughly estimated at II 6 - two-thirds to the Mosque and one-third to the Islamic Centre.

\section{Minutes of the Meeting of the Trustees of the London Mosque Fund, held at 83 Swan Court, Chelsea, on Friday 8 October 1943 at $12.30 \mathrm{pm}$}

Present:

Sir Hassan Suhrawardy, Chairman

Earl Winterton 
Husain Said Bey, Esq.

Waris Ameer Ali, Esq.

Sir John Woodhead was also present.

I. The minutes of the meeting held on 20 August I943 were confirmed.

2. The bronze memorial tablet which was to be put up in the premises of the East London Mosque, was examined and approved by the Trustees. The Trustees authorised the Chairman to arrange with $\mathrm{Mr}$ Alistair MacDonald, the architect, to take charge of the tablet, insure it for $f_{60}$, and select a suitable place in the wall of the Reading Room of the Islamic Culture Centre and take necessary action to fix it there.

To provide against mishaps the Chairman was authorised to arrange for a photograph to be taken at a cost of about f.r.I2.6. The Chairman was to take necessary action to raise funds towards meeting the cost of putting up the Memorial tablet and send copies of the photograph to such persons of whom financial help was expected.

The Chairman was authorised to pay bill No. BW I037, on account of making and supplying all materials for the Bronze Memorial tablet with enamel lettering, amounting to f 46.5 .0$. . from Messrs. Osborne Company Limited, II7 Gower Street, London WGi.

Proposed by Sir Hassan Suhrawardy and agreed unanimously that the thanks of the Trustees be conveyed to Mr Alireza Shinjan, Secretary of the Turkish Halkevi, I4 Fitzhardinge Street, W I for very kindly writing the Arabic inscription as an act of friendship; also to convey the thanks of the Trustees to Mons. Kamal Labbane, Attaché to the Egyptian Embassy for kindly drawing up the Arabic Text of the Memorial tablet. To Mr A. Yusuf Ali, the Trustees were indebted, for being responsible for the English inscription.

3. The Trustees considered the correspondence connected with the Notice of Termination of the Agreement with the Jamiat-ul-Muslimin as agents of the Trustees dated 3 September 1943, their reply dated Io September and letter dated I October I943, from Messrs. Cardew Smith \& Sons, Solicitors on behalf of the Trustees to the Jamiat-ulMuslimin. ${ }^{153}$ It was decided that further legal action be postponed till

\footnotetext{
${ }^{153}$ Through their solicitors, the Trustees served the notice of termination on 3 September I943, cancelling the Jamiat's authority to act as agents of the Trustees and requiring it to quit the premises of the East London Mosque. See BL, IOR, L/P\&J/ı2/468, fo. 269.
} 
after consideration of the reply received by Messrs. Cardew Smith \& Sons, the solicitors.

4. (a) The Trustees approved the proposal made by the Chairman that Dr Hasan Nachat Pasha, the Egyptian Ambassador, should be elected a Trustee in place of Sir Azizul Huque who had resigned on his return to India, and that His Excellency should be invited to accept the position of Vice-President of the Trustees. It was unanimously resolved that subject to his consent His Excellency should be elected a Trustee.

(b) The Chairman was authorised to issue a statement on behalf of the Trustees to remove misleading impressions caused by the action taken by the Jamiat-ul-Muslimin. ${ }^{.54}$

5. The Honorary Treasurer informed the Trustees that on account of investment of the donation of $\mathcal{E}_{\mathrm{I}}$,ooo received from $\mathrm{H}$. $\mathrm{H}$ the Nawab Ruler of Bahawalpur, the income from investments now amounted to $£ 26$ o per annum and the expenditure $£ 325$, not counting the expenditure for repairs and renewals. Sir Hassan Suhrawardy expressed the hope that by converting the telephone into a coin call box and installing the shilling-in-the-slot form of gas meters, there will be certain control in expenditure and other measure would be taken to reduce expenditures. Sir John Woodhead informed the Trustees that he hoped before Sir Hassan Suhrawardy left England it would be possible for him to secure the services of a suitable Muslim gentleman to take over the duties of Honorary Treasurer. ${ }^{155}$ Sir John Woodhead will be glad to give all assistance to the person elected to the position, and on this clear understanding he would be agreeable to stay on a little longer.

\footnotetext{
${ }^{154}$ This probably refers to the widely advertised public protest meeting that the Jamiatul-Muslimin held on Io October I943, at which it protested against the Trustees' notice of termination and presented its case for its refusal to accept it. According to the Jamiat, 'the India Office ran the affairs of the mosque through its representatives, the Trustees', who were not 'good Muslims and put the interests of the British Government before their duty to Islam' (see BL, IOR, L/P\&J/I2/468, fos 270-27I).

${ }^{155}$ It seems that the Jamiat-ul-Muslimin's point of having only Muslims on the committee was being taken up by the committee itself here. Waris Ameer Ali put it on record that he did not want Woodhead to resign. Woodhead, uncomfortable about the objections raised by the Jamiat with regard to his position as a non-Muslim Honorary Treasurer on the LMF Executive Committee, sought advice at the India Office. The India Office, suspicious of the Jamiat's political leanings, was reluctant to advise Woodhead's resignation as 'there will be no-one to keep an eye on developments from the official angle'. See Appendix III, and correspondence in the ELM Archives.
} 
Mr Waris Ameer Ali expressed the hope that it would be possible for Sir John Woodhead not to resign.

Sir Hassan Suhrawardy mentioned the name of a suitable Muslim gentleman from the Persian Legation but his acceptance of the responsibilities of the office depended on certain provisions to be made in the absence of Sir Hassan Suhrawardy.

6. The Trustees agreed that the next meeting would be held at 26 South Street, $W_{I}$, in the Committee Room attached to the office of Mons. Husain Said Bey and that he should be approached in time to arrange details. Mons. Husain Said Bey was also invited to discuss with Sir Hassan Suhrawardy the proposed arrangements regarding the management of the Mosque, and the contribution of the Executive Committee.

7. The meeting terminated with a vote of thanks to the Chairman.

Confirmed: H Nachat

\section{A meeting of the Executive Committee of the London Mosque Fund will be held at 83, Swan Court, Chelsea Manor Street, SW 3 on Friday, 8 October 1943 at 2.15 pm}

\section{AGENDA}

I. To confirm the minutes of the last meeting.

2. The Chairman to report the acceptance by him of the resignation from the Hon Secretary, Mr Hatim Attari, and to place correspondence in connection with it.

3. To consider:

a) Correspondence in connection with the notice of termination of agreement with the Jamiat-ul-Muslimin dated 3 September I943

b) Their reply dated io September

c) Letter dated i October on behalf of the Trustees from Messrs. Cardew, Smith \& Ross, Solicitors, to the Jamiat-ul-Muslimin

4. To place on record the action taken by the Chairman on behalf of the Trustees and Executive Committee.

5. Finances. Report by the Hon Treasurer. 
6. To consider:

a) Re-constitution of the Executive Committee

b) The scheme for the management of the Mosque

c) Arrangements during the temporary absence of Sir Hassan Suhrawardy from England

7. Any other business.

Chairman

Minutes of the Meeting of the Executive Committee of the London Mosque Fund held at $8_{3}$ Swan Court, Chelsea, on Friday 8 October 1943 at 2.15 pm

Present:

Sir Hassan Suhrawardy (Chairman)

Mr Waris Ameer Ali

Mr Yusuf Ali

Sir John Woodhead (Hon Treasurer)

Syed M. Syeedulla (Hon Secretary)

Apologies for absence were received from Mr Kamal Lebbane.

I. The minutes of the meeting held on August 3I were read and confirmed.

2. Correspondence in connection with the resignation of Honorary Secretary-ship by Mr Hatim Attari which had been circulated was considered and recorded.

3. The Executive Committee considered the correspondence connected with the Notice of Termination of the Agreement with the Jamiat-ul-Muslimin as agents of the Trustees dated 3 September I943, their reply dated io September and letter dated I October 1943 from Messrs Cardew, Smith \& Ross, Solicitors on behalf of the trustees to the Jamiat-ul-Muslimin. It was decided that further legal action be postponed till after consideration of the reply received by Messrs. Cardew Smith \& Ross, the Solicitors.

4. The Executive Committee approved of the action taken by the Chairman on behalf of the Executive Committee.

5. The Hon Treasurer informed the Trustees that on account of investment of the donation of £i,ooo received from $\mathrm{H}$. $\mathrm{H}$ the Nawab Ruler of Bahawalpur, the income from investments now 
amounted to $£ 26$ o per annum and the expenditure $£ 325$, not counting the expenditure for repairs and renewals. Sir Hassan Suhrawardy expressed the hope that by converting the telephone into a coin call box and installing the shilling-in-the-slot form of gas meters, there will be a certain control in expenditure and other measures would also be taken to reduce expenditure.

Sir John Woodhead informed the Executive Committee that he hoped before Sir Hassan Suhrawardy left England it would be possible for him to secure the services of a suitable Muslim gentleman to take over the duties of Hon Treasurer. Sir John Woodhead will be glad to give all assistance to the person elected to the position and on this clear understanding he will be agreeable to staying on a little longer. $\mathrm{Mr}$ Waris Ameer Ali expressed the hope that it would be possible for Sir John Woodhead not to resign.

Sir Hassan Suhrawardy mentioned the name of a suitable Muslim gentleman from the Persian Legation but his acceptance of the responsibilities depended on certain provisions to be made in the absence of Sir Hassan Suhrawardy.

6. The Committee considered Item 6 (a) (b) and (c) and authorised the Chairman to take necessary action regarding the matter and interview the authority concerned.

The Chairman who was already authorised by the Trustees was also authorised by the Executive Committee to issue a statement to remove misleading impressions caused by the action taken by the Jamiat-ulMuslimin.

The Executive Committee agreed that the next meeting would be held at 26 South Street, WI in the Committee Room attached to the office of Mons Hussain Said Bey and that sufficient notice be given him to arrange details.

7. It was reported to the Executive Committee that the Trustees had authorized payment of bill No BW 1037 on account making and supplying all materials for the Bronze Memorial tablet with enamel lettering amounting to $£ 46.5 .0$ from Messrs. Osborn Co. Ltd. II7 Gower Street, London WGI.

To provide against mishap the Chairman was authorised to arrange for a photograph to be taken at a cost of about $£$ I.I2.6. The Chairman was to take necessary action to raise funds towards meeting the cost of putting up the Memorial tablet and send copies of the photograph to such persons of whom financial help was expected. 
The Bronze Memorial tablet which was to be put up in the premises of the East London Mosque, was examined and approved by the Executive Committee. The Chairman was authorised to arrange with Mr Alistair MacDonald, the Architect, to take charge of the Tablet, insure it for $f 60$, and select a suitable place in the wall of the Reading Room of the Islamic Culture Centre and take necessary action to fix it there.

The Chairman was authorised to take necessary action to raise funds to meet the deficit. After discussion, it was agreed that the Muslim members of the Executive Committee would annually subscribe any sum convenient to them to the Mosque Fund. ${ }^{15^{6}}$

The Meeting terminated with a vote of thanks to the Chairman.

\section{Minutes of a meeting of the Trustees of the London Mosque Fund held at the Royal Egyptian Embassy on Wednesday I December 1943 at 12.30 pm}

\section{Present:}

H.E Dr Hassan Nachat Pasha (Egyptian Ambassador - Vice President)

The Rt Hon Earl Winterton

Judge Waris Ameer Ali

Mr Hussein Mohammed Said

The minutes of the last meeting held on Friday 8 October were read and approved.

Lord Winterton began by saying, on behalf of the Trustees how pleased they all were to see His Excellency the Egyptian Ambassador in the chair. He felt very strongly that His Excellency's presence would render valuable help to the Trustees in the direction of the affairs of the Mosque.

Dr Hassan Nachat Pasha thanked Lord Winterton and the Trustees for their kind sentiments and for having asked him to become one of their number. He hoped that they would soon be able to overcome all their difficulties.

\footnotetext{
${ }^{156}$ It appears that the Trustees had decided to follow the example of the Jamiat-ulMuslimin, albeit flexibly, with regard to the meeting of the Trust's annual expenditure. The Jamiat was an organization with an annual membership subscription. See ELM Archives, Jamiat-ul-Muslimin membership records.
} 
Dr Hassan Nachat Pasha went on to say that he had heard of the trouble there had been between Sir Hassan Suhrawardy and some of the Moslems in England and he wanted to make it quite clear that as far as the Trustees were concerned there was nothing against their being of any religion or nationality. There was a distinction to be made between the Trustees, who were entrusted with the administration of money and the people who were entrusted with the services carried out on the premises of the Mosque itself. This latter committee should definitely be Mohammedan.

His Excellency said that he also wished to clear up the question of their Treasurer. There was a great deal of work to be done and they would then know where they stood.

Lord Winterton said he wished to propose Sir John Woodhead to continue with his support. He had been up till now such a valuable Treasurer and they still needed the benefit of his experience.

The other Trustees supported Lord Winterton.

Sir John Woodhead thanked the Committee but said he thought that perhaps the Treasurer should be a Mohammedan.

Dr Nachat Pasha assured Sir John Woodhead that this was not necessary.

Sir John Woodhead explained that at the present he was carrying out the duties of Secretary and that unless he had some of this work taken off his shoulders he did not feel he could take on the work of Treasurer.

Dr Hassan Nachat Pasha said that one of the Trustees then present would be appointed as Secretary.

Sir John Woodhead said that in that case he would be glad to continue as Treasurer.

Dr Hassan Nachat Pasha said that the Trustees all knew that Sir Hassan Suhrawardy had been having difficulties with the Jamiat-ulMuslimin who had been entrusted with the services in the Mosque. ${ }^{57}$

\footnotetext{
${ }^{157}$ According to a Metropolitan Police report, the Jamiat-ul-Muslimin had 'the support of most, if not all, of the Muslims living in this part of London. Certain of its members have worked hard in the interests of Islam and have helped in many ways indigent Muslims and others who have suffered misfortune.' The dispute with the Trustees of the LMF, which began soon after the inauguration of the East London Mosque in Commercial Road in August I94I, was over who would control the mosque's affairs - the Trustees or the leaders of the Jamiat. See BL, IOR, L/P\&J/12/468, fo. 267, 'Extract from Metropolitan Police report', i4 October I943.
} 
Judge Waris Ameer Ali said that he had warned Sir Hassan a long time before that he would have trouble with these people.

Dr Hassan Nachat Pasha said that Sir Hassan Suhrawardy had seen the difficulty of dealing with a self-constituted body. Dr Nachat understood that there was another Committee between the Board of Trustees and the work of the Mosque, which was the managing Committee.

Sir John Woodhead said that as far as he knew the Managing Committee had only met once.

Dr Nachat went on to inform the Trustees of another big project. All the Moslems were uniting to found a moslem and oriental cultural centre in London. They had been given a big house in Regents Park for this purpose and for the purpose of building a mosque after the war. They had decided to form this cultural centre where all the different moslem countries would be represented. There would be a committee for the management of all the mosques in England both outside London and in it. Dr Nachat suggested that the Board of Trustees should ask this committee if they would undertake the management of the East London Mosque.

Sir John Woodhead said that from the legal point of view there should be no difficulty in this project.

Lord Winterton and Judge Ameer Ali said they thought the idea was excellent.

Dr Hassan Nachat Pasha said that when he heard of the difficulties the mosque was experiencing, he wrote to the King of Egypt to ask him if he would send an imam for this mosque and to ask if, as there was not enough money to pay an imam, he could be paid at least for the first year or so. Unfortunately His Majesty was in hospital and Dr Nachat had as yet received no reply, but he had every hope that the reply would be favourable.

Judge Ameer Ali said that he supposed it would be difficult to find someone suitable in the middle of the war.

Dr Hassan Nachat Pasha replied that fortunately the sea route from Egypt was re-established and there should be no difficulty in sending someone over.

Judge Ameer Ali said that it was very important that they should have someone who had a really good influence. The mosque was frequented by the poor and uneducated moslems and it was 
most desirable that their spiritual and moral needs should not be forgotten.

Dr Nachat replied that if an imam was sent from Cairo he would always feel responsible to this Embassy.

Dr Nachat then read a letter he had received from Sir Hassan Suhrawardy:

"I am however worried about the Mosque and shall be most grateful if you will very kindly let me know what has happened, since I left London on the 26 October. I wanted to see you before I left but on account of leaving at a moment's notice unexpectedly, I couldn't let you know that they were trying to arrange a deputation to wait on you consisting of persons who would apparently look like disinterested persons but were really emissaries trying to take possession of the Mosque by indirect methods. I have explained the situation to H.E. Hassanein Pasha and His Eminence Sheikh Al Maraghi. I have sent you all papers received up to date from the solicitors and also a copy of the Minutes of the Meeting of the Trustees held on Friday October 8 at which Your Excellency was elected a Trustee and the Vice President, and thus the future of the Mosque was put in your hands."

Sir John Woodhead said he was not happy at the thought of starting legal proceedings against the Jamiat-ul-Muslimin.

Dr Hassan Nachat Pasha said he did not think it would come to that. He intended to speak to some of them as Moslem to Moslem.

Lord Winterton said that he had been told that a meeting of protest had been held by the Jamiat-ul-Muslimin in North London. ${ }^{15^{8}}$

Sir John Woodhead said that there had been such a meeting but nothing had come of it.

Mr Hussein Mohammed Said then read cables exchanged between His Excellency the Egyptian Ambassador and the Chief of the Royal Cabinet, regarding the East London Mosque.

"Boustane London. Secretary Jamiat-ul-Muslimin cables following Trustees East London Mosque contemplate immediate handing over

\footnotetext{
${ }^{158}$ British intelligence reports noted this meeting, which took place at Conway Hall. Several hundred Muslims and a small number of non-Muslims, in particular those with Indian Nationalist sympathies, were present. Delegates had also arrived from the Jamiat-ulMuslimin's Newcastle, Manchester, and Glasgow branches. See BL, IOR, L/P\&J/I2/468, fos $27 \mathrm{I}^{-2} 272$.
} 
management Mosque to non-Muslim control. Please enquire and forward all available information kind regards. Chief Royal Cabinet"

"Excellency Chief Royal Cabinet, Cairo. East London Mosque is established under trust fund IgIo president Aga Khan money collected from various sources. Since foundation fund two trustees were nonmoslems now only one Lord Winterton. Trustees appointed executive committee for management of the mosque amongst who were two non-moslems now all members executive committee are moslems. The self-formed Jamiat ul Muslimin who were lately authorised by the executive committee to manage the mosque disagreed with Suhrawardy who is chairman of the executive Committee. Consequently executive committee put end to the delegation given to Jamiat ul Muslimin to manage the mosque wanting to place mosque under direct control. Allegations by El Jamiat are totally unfounded. Report follows by post best wishes Ambassador."

"Excellency Hassanein Pacha, Palais Abdine, Caro. Référence ma dépêche du I2 octobre concernant East London Mosque vous prie soumettre qu'afin prevenir dissention facheuse [sic] entre mussulmans residant $[s i c]$ ici ai accepté poste vice président Trustees dite mosque. Pour arriver cette fin il est nécessaire avoir un imam connaissant anglais pour diriger services religieux d'une manière digne. Fonds trust ne suffisent pas pour paiement salaire imam et si ces trais sont supportés par Wakfs ${ }^{159}$ publiques ou royaux le geste serait très bien apprécié. Amitiés. Nachat."

Dr Hassan Nachat Pasha then proposed that Mr Hussein Mohammed Said be appointed secretary.

The other Trustees seconded this proposal which was carried unanimously.

This concluded the business of the day.

\footnotetext{
${ }^{159} \mathrm{Also}$ spelt waqf, this is an inalienable religious endowment in Islamic law, typically denoting a building or plot of land for Muslim religious or charitable purposes. The donated assets are held by a charitable trust.

${ }^{160}$ Translation of paragraph: 'Excellency Hassanein Pacha, Palais Abdine, Cairo. With reference to my letter of I2 October concerning the East London Mosque, may I ask you to agree, in order to prevent regrettable disagreement amongst Muslims resident here, I have accepted the post of vice president of the Trustees of the mosque. To meet this aim it is necessary to have an imam who speaks English to run the religious services in a worthy manner. The Trust funds are not enough to pay a salary for an imam and if these aspects could be supported by public or private Wakfs, the gesture would be very much appreciated. Best wishes. Nachat.'
} 
India Office

Whitehall

SWI

7 July I944

\section{Dear Mr Levrane}

I am sending you the papers about which I believe I spoke to you and in connection with which you will find a resolution of the Trustees at their meeting held, if my memory is correct, in December last. You will find a note which I wrote on the matter over a year ago.

The Trustees decided that no change should be made as regards the names in which the securities are held, but they decided that the appointment of the existing Trustees should be placed on a proper footing and that the Deed as settled by counsel should be executed.

The difficulty has been that His Highness the Aga Khan is in Switzerland. At one time I though that we could get the Deed executed by sending it to him in Switzerland, but finally came to the conclusion that this would be very difficult and so I have done nothing in the matter so far. Now that the war is drawing to a close I think the best course is to wait until peace has been declared and His Excellency the Aga Khan again comes to this country.

Another reason I did not proceed with the matter was that the Trustees were changing rather rapidly and indeed the Deed which was settled over a year ago would now have to be amended in view of the changes which have taken place in the Trustees during the last twelve months.

I have also mentioned this matter to M. Said, who, I think, is fairly acquainted with the matter.

Yours sincerely

J. Woodhead

\section{Minutes of a meeting of the Trustees of the London Mosque Fund held at the Royal Egyptian Embassy on 22 June 1944}

\section{Present:}

H.E Sr Hassan Nachat Pasha, Egyptian Ambassador and VicePresident 
Judge Waris Ameer Ali

Monsieur Hussein Mohammed Said

Sir John Woodhead, Honorary Treasurer was also present

I. The minutes of the last meeting held on I December i943 were approved and signed.

2. On the proposal of Mr Waris Ameer Ali and seconded by Monsieur Hussein Mohammed Said the Committee accounts for the year ended 3I March 1943 were approved and signed by His Excellency the Chairman and the Honorary Treasurer.

3. The Honorary Treasurer placed before the meeting, the accounts for the year ended 3I March I944. They were approved. The accounts with the Auditors' certificate have not yet been received. On receipt they will be placed before the next meeting and formally approved.

4. The Honorary Treasurer reported that the caretaker at the Mosque is paid partly from the Indigent Moslems Burial Fund. The amount paid from this Fund is $f_{\mathrm{I}} \mathrm{p}$ per week. In view of the fact that the only work done by the caretaker for the Burial Fund is in connection with the preparation of bodies for burial, for which he is paid separately, it was decided that, with effect from the beginning of July the sum of f. I per week which is now paid from the Burial Fund should be paid from the London Mosque Fund.

5. It was recorded that Mr M.R. Zada has resigned from the position of Trustee.

6. Sir John Woodhead informed the meeting that he was leaving England and would be away for at least six months. ${ }^{16 t}$ It was therefore necessary to appoint someone to carry on the work of Honorary Treasurer. It was proposed by Monsieur Hussein Mohammed Said and seconded by Mr Waris Ameer Ali that Monsieur Kamal El Labbane should be appointed Honorary Treasurer.

This concluded the business of the day.

\footnotetext{
${ }^{161}$ Woodhead had recently been appointed to chair the Bengal Famine Inquiry Commission and so was travelling to India. This Commission, established by the Government of India under Ordinance No. XXVIII of 1944, first met in July of that year. Its report, which was issued in April I945, gave a comprehensive and detailed account of the events in Bengal and of related happenings elsewhere. For more detail, see Henry Knight, Food Administration in India, 1939-1947 (Stanford, CA, 1954), ch. 8, 'The Bengal famine of I943: background'.
} 
[Signature at the end is impossible to decipher - but is probably that of Said, the Chairman at the next meeting]

\section{$[\mathrm{COPY}]$}

\section{LONDON MOSQUE FUND \\ Trust Deed}

[dated 1926]

The Trust Deed provides for (i) Trustees; (ii) Executive Committee.

(i) The Trustees present are:

H.H the Aga Khan, F.C., G.C.S.I., G.C.I.E., etc.

c/c The Swiss Hotel

London Eı President

H.E. Hassan Nachat Pasha

Egyptian Ambassador

75 South Audley Street

London W I Vice-President

The Rt Hon Earl Winterton M.P

6r Eccleston Square

London SWI

Judge W. Ameer Ali, C.I.E., I.C.S., (Retd)

India House

Aldwych

London $\mathrm{WC}_{2}$

Private address: i Alexandra Court, Queens Gate, London SW7

Monsieur H.M. Said

Egyptian Embassy

75 South Audley Street

London $\mathrm{W}_{\mathrm{I}}$

Lt. Col. Sir Hassan Suhrawardy O.B.E

4 Tughlak Road

New Delhi

India

Mr Zada was a Trustee, but has resigned as he has now left England. His resignation should be formally accepted at the next meeting of the Trustees. 
According to the Trust Deed, the Muslim Member of the Council of the Secretary of State for India is entitled to be appointed as a Trustee. Sir Hassan Suhrawardy is now the Muslim Member. His term of office as Adviser to the Secretary of State expires in July I944. His successor, when appointed, should be appointed a Trustee. I believe that Sir Hassan Suhrawardy wishes to remain a Trustee although he has returned to India.

(ii) The Executive Committee consists of the following:

Lt. Col. Sir Hassan Suhrawardy O.B.E

4 Tughlak Road

New Delhi

India

Judge W. Ameer Ali, G.I.E., I.G.S., (Retd)

India House

Aldwych

London $\mathrm{WC}_{2}$

Mr Kemal Lebbane

Egyptian Embassy

75 South Audley Street

London $\mathrm{W}_{\mathrm{I}}$

Private address: 26 South Street, Mayfair, London WI

[handwritten next to this 'now left England']

Mr A. Yusuf Ali C.B.E

3 Mansel Road

Wimbledon

SWi9

Mr Hatim Attari

4I Berkeley Square

London $\mathrm{W}_{\mathrm{I}}$

Sheikh Abdul Hamid

34A Buckingham Gate

London SWI

Mr Mohammed Syed Ullah

(Hon Secretary)

India House

Aldwych

London $\mathrm{WC}_{2}$

Private Address: 46 Kingswood Court, West End Lane, London NW6 
Dr A.J. Arberry

Balliol College

Oxford

(When questions concerning the Culture Centre are under consideration)

b) Investments

The investments consist of:

$£ 4$, I30 $\quad 3 \frac{1}{1} \%$ War Stock (1952)

$£ 2,500 \quad 3 \% \frac{1 / 2}{2} \% \quad$ Conversion Stock (196I)

EI, ooo $\quad 3 \% \quad$ Savings Bonds

The interest on these investments is credited automatically to the account of the London Mosque Fund at the Bank of England. The Dividends are paid free of Income Tax. The scrip is held in safe custody by the Bank of England.

c) Property

The Trustees own the premises at $44^{6}-45^{\circ}$ Commercial Road, EI. The title deeds are with the Solicitors. The property is insured with The Guardian Assurance Co. against damage by fire. The premium is $£ 3.3 .-\mathrm{d}$ a year.

d) Income Tax and Land Tax

No income tax or land tax is payable on the property in Commercial Road. Although the Income tax and Land Tax authorities have agreed to this, a demand was received for payment of these taxes in January 1944. I think this demand was made in error, as on receipt of the papers, I telephoned to the Income Tax authorities, told them the same thing had happened last year and said that if I did not hear from them again I would presume a mistake had been made this year also. I have heard nothing further and have paid no further attention to the demand note. The property in Commercial Road is entitled to exemption from Income Tax and Land Tax because it is owned by a charitable organisation (The London Mosque Fund) and used for "charitable" purposes. The property is also exempt from the payment of war Damage Insurance Premium.

e) Architect

The Architect is Mr Alaister C. MacDonald, F.R.I.B.A., F.R.I.A.S., 29 Avenue Road, London NW8. (Telephone: Primrose i622). He 
supervises the carrying out of any repairs to the property. If any repairs are necessary he will arrange to carry them out.

\section{f). Caretaker}

The caretaker is Mr Ali Basha. His wages are as follows:

i) as caretaker, £i.I7.od per week less Is/Iod a week on account of insurance contributions

ii) As Teacher of Koran, $£ 5$ a month (nos. i and ii paid for by the London Mosque Fund)

iii) $E_{\text {I }}$ per week paid from the Indigent Muslims Burial Fund.

The insurance books on account of Unemployment and Health are kept by the Trustees and are stamped periodically. The cost of the weekly stamps is 3 s/8d of which Is/Iod, as indicated above, is recovered from Ali Basha and Is/Iod paid from the funds of the Trustees.

Ali Basha is provided with free quarters at the Mosque and also with electric light and gas free.

I have suggested, vide separate note attached, that the $f_{\mathrm{I}}$ a week at present paid from the Indigent Muslim Burial Fund should be paid from the Mosque Fund.

f) General Expenditure

Apart from Ali Basha's wages, the main items of expenditure are:

i) General Rates

ii) Water Rate

iii) Electricity

iv) Gas

v) Telephone

vi) Repairs

vii) Miscellaneous expenditure incurred by Ali Basha.

There are two telephones at the Mosque. One is a coin box telephone. This latter is used by the general public. Ali Basha has the key to the coin box and periodically opens it and remits the money to the Trustees.

It has been proposed that there should be a shilling-in-the-slot meter for gas, but this has not been introduced as yet.

There are two accounts at the Bank of England:

a) The London Mosque Fund account

b) The London Mosque Fund "B" account 
The "B" account was opened with the object of keeping the expenditure and receipts of the Culture Centre separate. While the Culture Gentre was functioning, or rather endeavouring to function, ${ }^{162}$ the following items of expenditure used to be debited in part to the "B" account:

General Rate

Water Rate

Electricity

Gas

Telephone Account

Caretaker's wages

- one third to the " $\mathrm{B}$ " account.

Wages of Teacher of Koran - Half to the "B" account.

I have not made this division since October 1943 because the Culture Centre is not in existence. ${ }^{163}$ For the present the " $\mathrm{B}$ " account is not being operated on and if the Culture Centre is not revived it might just as well be closed and its small balance transferred to the main account.

g) $\underline{\text { Audit }}$

The audit is carried out by Messrs. Feasey, Hull and Feasey, 5 Norfolk Street, Strand, $\mathrm{WC}_{2}$. The audited accounts are approved at a meeting of the Trustees.

h) Solicitors

The Solicitors are Messrs. Cardew Smith and Ross, 27 Ely Place, EGi. They are very helpful in many matters. They are paid for the work they do.

\section{i) Cheques}

Cheques require to be signed by a Trustee and the Hon Treasurer. The Bank of England are the Trustees' Bankers.

j) The British Council

When the Mosque was opened it was hoped that in addition to being a place of worship it would be a Culture Centre. The British Council

\footnotetext{
${ }^{162}$ This suggests that the Islamic Culture Centre was no longer conducting any activities.

${ }^{163}$ Date of closure could not be established.
} 
gave a capital grant of $£$ IOo towards the establishment of a library and for one year gave a grant of $£ 75$ towards the cost of running the Culture Centre.

Dr Arberry and also a representative of the British Council attended meetings of the Executive Committee when questions concerning the Gulture Centre were under discussion.

The attempt to establish a Culture Centre has failed completely and at present the Centre is not operating.

k) $\underline{\text { Furniture }}$

There is on the appropriate file a stock list showing the furniture etc. which is the property of the Trustees of the Mosque. The Jamiat-ulMuslimin supplied chairs and tables for the large rooms at the back of the Mosque which, in addition to being used as Prayer rooms when the congregation is large, are also used for entertaining the worshippers on the occasions of the great festivals. The Jamiat-ul-Muslimin claim that these are their own; they have not been entered on the stock list.

\section{LONDON MOSQUE FUND}

The caretaker, Mr Ali Basha, is at present paid -

a) from the Mosque Fund

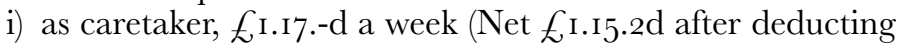
Unemployment and Health insurance

ii) as Teacher of Koran, $£ 5$ a month

b) from the Indigent Muslims Burial Fund $f_{\mathrm{I}}$ a week

In view of the amount of work done by $\mathrm{Mr}$ Ali Basha for the Burial Fund a payment of $\mathcal{E}^{\mathrm{I}}$ a week does not appear to be justified.

The Mosque Fund is now in a stronger financial position - vide the annexed Memo - and I suggest that as from I April I944 the $£_{\text {I a week }}$ now met out of the Burial Fund should be charged to the Mosque Fund.

J.A. Woodhead

Hon Treasurer 


\section{Estimate of Receipts and Expenditure of the London Mosque Fund}

\section{Expenditure}

A. Actuals of $1942 / 3$ :

Water Rate

£ $18 . \quad$ o. 4

General Rate

£ 47 . Iо. 0

Telephone

Gas

Electricity

£ $8 . \quad$ I4. 2

£ $35 . \quad$ o. 2

Insurance

Fee for registering premises as place for

£. 8. Iо. 6

the solemnization of marriages

\&3. 3. $\quad$ o

National Health Insce.

Miscellaneous

\&3. o. o

EII. I4. 4

£2I. I6. IO

Total: $\quad$ \& $5^{6}$. $19 . \quad 4^{164}$

Estimated:

Clerical Assistance

Caretaker and reader of Koran:

I. caretaker at $\mathcal{E}^{\mathrm{I} . \mathrm{I} 5} 5.2$ a week

2. reader of Koran $£ 5$ a month

Audit fee

$$
\text { \&6. o. o }
$$

£ 9i. $\quad$ 8. $\quad$ o

E 6o. o. o

\&5. o. o

Total: £ I $57 . \quad$ 8. $\quad \mathrm{O}^{\mathrm{I} 65}$

Grand total: $\AA_{3} 3^{\mathrm{I} 6.7 \cdot 4^{\mathrm{I}}}{ }^{\mathrm{m}}$

\section{Receipts}

Conversion Stock Dividends

War Stock Dividends

Savings Bonds Dividends

H.H. the Aga Khan's Grant

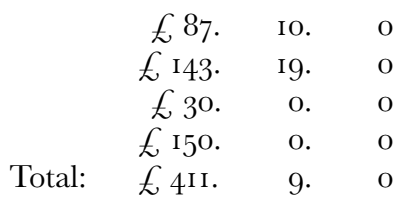

Excess of receipts over expenditure: $\AA_{\text {97.1.10 }}{ }^{167}$

Note: This estimate takes no account of expenditure on repairs. It is difficult to say what this will amount to over a period of years. An average annual figure of $£ 65$ may be taken.

\footnotetext{
${ }^{164}$ This total should be $£ \mathrm{I} 57 \cdot 9 \cdot 4$.

${ }^{165}$ This appears not to include the audit fee.

${ }^{166}$ This total should be $£ 3$ I $4.17 \cdot 4$ (or $£ 3$ I9.7.4 with the audit fee).

${ }^{167}$ This total should be $£ 96$.II.8 (or $£ 9$ I.II.8 if the audit fee is taken into account).
} 


\section{Minutes of the Meeting of the Trustees of the London Mosque Fund held at the Royal Egyptian Embassy I5 February 1946}

\section{Present:}

Mons Hussein Mohammed Said (in the Chair)

Sir Torick Ameer Ali*

Waris Ameer Ali

Sir John Woodhead was also present.

A letter of apology of absence had been received from Earl Winterton.

I. The minutes of the last Meeting of the Trustees held on 22 June I944 were read and confirmed.

2. Judge Waris Ameer Ali said that he was prepared to agree that his letter of resignation of 22 June I945, from his Trusteeship, should be treated as withdrawn and cancelled. It was accordingly recorded that Judge Waris Ameer Ali was still a Trustee.

3. The Meeting was informed that Monsieur Kamal El Labbane had resigned the post of Hon Treasurer on his return to Egypt. It was proposed by Monsieur H.M. Said and seconded by Sir Torick Ameer Ali that Sir John Woodhead be appointed Honorary Treasurer and that he be authorized to sign (together with one of the Trustees) cheques drawn on the London Mosque Fund's account at the Bank of England.

4. It was placed on recorded that under Clause 6 of the declaration of Trust, Sir Torick Ameer Ali, the Moslem Adviser to the Secretary of State for India, had been appointed a Trustee in place of Sir Hassan Suhrawardy who vacated the office. This change dates from November, I944.

5. The appointment of Md. Saiyid Abbas as caretaker of the East London Mosque from 25July I945 at a salary of $\AA^{2.17}$.od a week was confirmed.

6. It was decided that the Hon Treasurer should be authorized, in consultation with Mr Alister MacDonald, the architect, to carry out the necessary repairs to the Mosque building in Commercial Road.

7. The meeting concluded with a vote of thanks to the Chair. 
I agree to the appointment of Mr John Woodhead as Hon Treasurer of the London Mosque Fund in succession to Monsieur Kamal El Labbane, who has resigned that office on his return to Egypt.

2I February I946 [signature unclear]

Ref: CCO/I475

BANK OF ENGLAND

26 February 1946

\section{Copy}

The Honorary Treasurer

The London Mosque Fund

75 South Audley St. WI

Dear Sir

I write with reference to your three letters of the I6th instant in which the Bank are -

I. Requested to transfer the balance, viz. £57.8.o of the London Mosque Fund "B" account to the Fund's ordinary account and subsequently to close the former account.

2. Notified of your appointment as Honorary Treasurer in place of M.K. El Labbane, supplied with a certified copy of the Resolution of I5 $_{5}$ February making the appointment and given your confirmation of their action in paying certain cheques signed by two trustees.

3. Advised of the cancellation of the resignation, dated 22 June last, of $\mathrm{Mr}$ Waris Ameer Ali and given a list of the present trustees of the Fund.

With regard to I. above, I would say that to be effective this letter must be signed by the Honorary Treasurer and one of the trustees. I shall be obliged, therefore, if you will kindly arrange for the Bank to receive confirmation of these instructions over the signature of one of the trustees.

With regard to 3. above, it is noted that although Sir Torick Ameer Ali seconds the resolution of I $5_{5}$ February his name does not appear in your list of the present trustees. In the circumstances perhaps you will be good enough to let me know whether Sir Torick continues to be a trustee.

I would also refer to the Bank's letter of 23 October last and draw your attention to the fact that the Bank still await the resolution appointing 
H.E Hassan Nachat Pasha a trustee, together with a specimen of his signature.

A resolution is also required stating which officers may order the delivery of, or otherwise deal with, the securities which are now, or may hereafter be, held by the Bank on behalf of the Fund.

You will also notice from the Bank's letter of 23 October that the name of Lt. Col. Sir Hassan Suhrarwardy, O.B.E who is no longer a trustee, appears as one of the stockholders on the certificate for $\mathcal{E}_{\mathrm{I}}$,ooo $3 \%$ savings bonds $1960 / 70$ held by the Bank on behalf of the Fund.

Yours faithfully

(signed) Gwylm-Williams [name illegible]

For Chief Cashier.

27 February 1946

Sir John Woodhead

G.C.I.E., K.C.S.I

Woking

Dear Sir John

The enclosed letter arrived from the Bank of England this morning. As it is only possible to deal with a portion of the letter, I am sending you a copy. I have prepared the required confirmation for the transfer of the $£ 57$ and this can be signed when you come in, when all the queries can probably be answered together.

Statements of Accounts from the Banks are in: -

$\begin{array}{lcccc}\text { Barclays - } & \text { Credit } & \text { Balance } & \text { I.M.B.F ..... } & £ 662.19 .6 \\ \text { B. of E. } & " & " & \text { Ldn Mosque } & £ 344.16 .4\end{array}$

A chit has been received to the effect that $£ 5^{\circ}$ has been paid into Barclays (via Coutts) on behalf of the Aga Khan, dated I January 1946.

Yours sincerely

[signature unclear] 
Minutes of the Trustees of the London Mosque Fund held at the Royal Egyptian Embassy on 12 December 1946

\section{Present:}

Monsieur Hussein Mohammed Said (in the Chair)

Sir Torick Ameer Ali

Waris Ameer Ali Esq.

Sir John Woodhead Hon Treasurer

An apology of absence had been received from Lord Winterton

I. The minutes of the last meeting of the Trustees held on 15 February I946 were read and confirmed.

2. The Audited Accounts for the years ended 3I March I944; 3I March I945 and 3I March I946 were approved (and signed by the Chairman and the Hon Treasurer) on the proposal of Mr Waris Ameer Ali and seconded by Sir Torick Ameer Ali.

3. On the proposal of Monsieur H.M. Said and seconded by Sir Torick Ameer Ali a vote of thanks was passed to the Auditors, Messrs. Feasy, Hull and Feasy, for their services during the years I943, I944, I945, \& $1945^{-46}$. It was also decided that Messrs. Feasy, Hull and Feasy be appointed auditors for the [year] 1946-47.

4. On the proposal of Sir Torick Ameer Ali and seconded by Mr Waris Ameer Ali, approval was given to the appointment as caretaker at $f^{2}$ I $7 \mathrm{~s}$ a week of:

i) F.B Powell, from 25 June 1946 to 22 September 1946

ii) Kale Khan from 23 September 1946

5. On the proposal of Monsieur H.M Said, seconded by Sir Torick Ameer Ali, the Trustees recorded with deepest regret the death of Sir Hassan Suhrawardy, who had been a Trustee for some years and who had taken the keenest interest in the establishment of the Mosque in Commercial Road. It was decided that a letter of condolence be sent to his daughter, Mrs Ikramullah ${ }^{168}$ in New Delhi.

6. The question of the appointment of an additional Trustee or Trustees was postponed for consideration at a later meeting. In the

\footnotetext{
${ }^{168}$ Sir Hassan Suhrawardy's daughter, Shaista (1915-2000), was married to Mohammad Ikramullah, who was appointed Pakistan's High Commissioner to the United Kingdom in the I950s. For reminiscences about her father, see Shaista Suhrawardy Ikramullah, From Purdah to Parliament (London, I963).
} 
meantime Sir Torick Ameer Ali agreed to review the position of the Trustees of the Trust Fund with the assistance of the Hon Treasurer.

7. The Hon Treasurer reported that he had hoped to have for presentation to the Trustees at this meeting an estimate of the cost of repairs to the Mosque. Unfortunately, it had not been received. The Hon Treasurer was authorised to carry out the necessary repairs.

8. The financial position of the Trust Fund as shown in the attached sheet by the Hon Treasurer was reviewed. The Hon Treasurer pointed out that the grant of $\mathcal{E}_{\mathrm{I} 5 \mathrm{O}}$ a year from $\mathrm{H}$. $\mathrm{H}$ the Aga Khan would cease in 1949. After that date additional revenue would be imperative.

9. The meeting concluded with a vote of thanks to the Hon Treasurer for the work he had done, and to Monsieur H.M Said for taking the Chair.

Confirmed: W. Ameer Ali 5 February 1948

\section{EXPENDITURE}

Receipt

$3 \frac{1}{2} \%$ Conversion St. Dividends

$3 \frac{1}{2} \%$ War Stock Dividends

Savings Bonds (3\%)

H.H. the Aga Khan's grant

£ 87. Iо. о

£ I43. I9. о

E 3 o. o. o

Total: f4II.9.0

Expenditure

a) Actuals of $1945 / 6$ :

General and Water Rates

Gas and Electric Light

Telephone

Insurance

Postage \& Sundries

f i5

b) Estimated:

Caretaker ( $\mathcal{2}^{2.17}$ per week)

Clerical assistance

Audit Fee

National Health, Pension \& Unemployment

\& $5^{2 .} \quad \mathrm{I} 5$

£ 30. I2. 8

£ 27. I3. 9

E $3 . \quad 3 . \quad 0$

£ $2 . \quad$ I6. 8

Insurance $£ 2$ s iod per week

£ I48. $4 . \quad$ o

£ 26 . o. o

\& 5 o. o

\& $7.7 . \quad 4$

Total: f303.I2.5

Excess of Receipts over Expenditure:

E 
This estimate takes no account of expenditure on repairs. $\mathrm{Mr}$ Macdonald is having an estimate prepared of the cost of repairs and it is roughly estimated that it will cost us $£ 3$ oo (exclusive of the amount paid by the War Damage) to put the buildings into good repair.

On I I September 1946 the balance at the credit of the fund was about £6oo.

\section{August 1947}

My dear Sir John Woodhead

In reply to yours of 2I August I have much pleasure in returning the transfer deeds duly signed and witnessed.

I too have been wondering what happened to the papers about which we wanted legal opinion concerning the assignment of the London Mosque Trust to a new body. I asked my brother the other day and he said that he had forwarded a legal opinion with the papers to Hussein Bey to whom I am therefore also writing.

Perhaps you may be kind enough to remind him also if you see him at any time. I will convey the gist of Hussein Bey's reply to you when received unless you have got any information of him first.

The matter whether my brother's trusteeship has lapsed with the lapse of his function as Adviser to the S. of S. for India ought I think also to be considered, if it has, he might be copied as a Trustee to keep our numbers up until further arrangements are made.

Very sincerely

Waris Ameer Ali

[handwritten letter]

$$
\begin{aligned}
& \text { Pollingfold } \\
& \text { Rudgwick, Sussex }
\end{aligned}
$$$$
\text { 3I. } 8.47
$$

Dear Sir John

I saw the solicitors Norton, Rose Greenwold in 6 Old Bond St. who are doing the scheme for the Central Mosque in May, and they advised definitely in favour of a similar charitable corporation. 
Hussein Said Pasha was I think of this opinion that it was best to wait until then.

Central Mosque Scheme was on its way, though.

I have proposed calling on him on I $_{2}$ September to see what his position is and ascertain his views.

I rather think I was a Trustee in my official capacity [illegible] ceased to be so.

Yrs Sincerely

Torick Ameer Ali

I enclose the solicitor's letter. I did not yet receive [illegible] advice.

Metropolitan Water Board

New River Road

Rosebery Avenue

London EGI

24 July 1947

The Honorary Treasurer

London Mosque Fund

26 South Street

LONDON W

Ref: F/RSRR/E.2I5630

Dear Sir

\section{Commercial Road}

It is understood that it is proposed to carry out alterations in the water supply arrangements at the above premises, and that a request has been addressed to the Board's Inspector with reference to the fixing of a tap on the upper floor.

I have to advise you that the Board do not carry out work of this nature on private premises, and that you should instruct your own plumber to carry out the desired alterations.

All work should satisfy the Board's requirements, and I shall be glad to learn when this has been done.

I am, yours faithfully,

Distribution Engineer 
In the name of Allah the Beneficent, The Merciful.

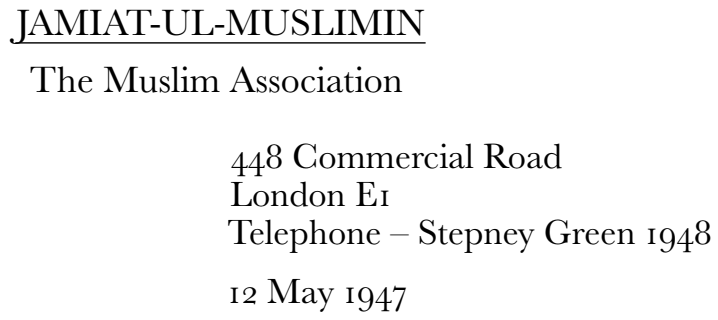

To Sir John Woodhead, Esq.

Hon Treasurer

London Mosque Fund

26 South Street

London $\mathrm{WI}^{{ }^{169}}$

Dear Sir John Woodhead

I thank you for appointing me as caretaker for the London Mosque and I have the honour to send herewith the required unemployment and National Health Insurance cards.

As to the Income Tax Code No., and tax deductions I have to say that so far I have never been in a position to pay any such tax.

For your information I beg to say that I am married and have three children of $5, \& 3^{1 / 2}$ years and 8 months ages.

Yours faithfully AM Khan

\section{Minutes of a Meeting of the Trustees of the London Mosque Fund held at the Royal Egyptian Embassy on 5 February $194^{8}$}

Present: Judge Waris Ameer Ali (In the Chair)

Lord Winterton

Sir Torick Ameer Ali

Sir John Woodhead (Hon Treasurer)

\footnotetext{
${ }^{169}$ The members of the Jamiat appear to have been using the address in Commercial Road, while the Trustees of the Mosque were based elsewhere.
} 
I. The minutes of the last meeting of the Trustees held on I2 December 1946 were read and confirmed.

2. The audited accounts for the year ending 3I March 1947 were approved and signed by the Chairman of the meeting (Judge Waris Ameer Ali) and the Hon Treasurer.

3. A vote of thanks was passed to the Auditors, Messrs. Feasey, Hull \& Feasey for their services during the year i946-47. It was resolved that they be appointed Auditors for the year ending $3 \mathrm{I}$ March 1948.

4. On the proposal of Lord Winterton and seconded by Sir Torick Ameer Ali, the Trustees recorded with the deepest regret the sudden death of Mon. Hussein Mohammed Said Bey who had been a Trustee for some years and who had always taken a keen interest in the work of the Trust. It was decided that a letter of condolence be sent to his brother in Egypt. ${ }^{170}$

5. Considered a letter dated 26 March 1947 from Dr Hassan Nachat Pacha ${ }^{171}$ in which he expressed a desire to resign from the Trust on the ground that he is now living in Egypt. It was resolved that Dr Hassan Nachat Pacha be asked to continue as a Trustee until 30 September 1948, by which time other persons will have been appointed as Trustees.

6. It was pointed out that Sir Torick Ameer Ali became a Trustee by virtue of the provision of the Deed of Trust which lays down that the Mohammedan Member of the Council of the Secretary of State for India shall be entitled to be appointed a Trustee so long as he continues to hold that Office. Owing to India having obtained its independence, ${ }^{172}$ the Secretary of State of India ceased to exist with effect from I August 1947, and the posts of Members of the Council of the Secretary of State for India (called Advisers under the Government of India Act of I935) ceased to exist from that date.

Sir Torick desired to continue as a Trustee and on the proposal of Lord Winterton, seconded by Judge Waris Ameer Ali, it was decided to re-appoint Sir Torick Ameer Ali as a Trustee with effect from I5 August 1947 .

\footnotetext{
${ }^{170}$ See ELM Archives, Woodhead to Hussein Mohamed Said's brother in Cairo, I4January I948.

${ }^{171}$ ELM Archives.

${ }^{172}$ India officially attained its independence on ${ }_{5} 5$ August I947, while Pakistan celebrated its establishment as a sovereign state on I4 August 1947.
} 
7. On the proposal of Judge Waris Ameer Ali, seconded by Sir Torick Ameer Ali, it was resolved that the following gentlemen, provided they are agreeable, be appointed as Trustees:

Mr. Hatim Attari, 4I, Berkeley Square, London WI

Mr Fazal Shah, 36, Whitchurch Lane, London Eı4

Mr Ghulam Mohammed, 59, Canton Street, London EI4

8. Considered the Note (attached) by the Hon Treasurer suggesting, for the reasons given in that Note, that following the example of the London Central Mosque Fund, a Trust Corporation be formed: proposed by Lord Winterton and seconded by Judge Waris Ameer Ali, that this course be followed.

9. The Hon Treasurer stated that the receipts and expenditure for the year $1946-47$ had been as follows:

$\underline{\text { Receipts }}$

Dividends

Contribution

From H H the Aga Khan

Total $\underline{\text { Expenditure }}$

$\AA^{2} 6 \mathrm{I}$

$£ 394$

$\AA_{150^{173}}$

$£ 4^{\text {II }}$

$£ 394$

It was pointed out that without the contribution of $£ \mathrm{I} 5 \mathrm{O}$ from H. H. the Aga Khan there would be a heavy deficit. It was resolved that $\mathrm{H}$. $\mathrm{H}$. the Aga Khan be requested to be so good as to renew his subscription of $£ \mathrm{I} 5 \mathrm{O}$ a year for an additional period of three years, i.e. the years I950, I95 I and $1952 .{ }^{174}$

Io. It was reported that the cost of repairs had amounted to $£^{6} 5^{\mathrm{I}}$ inclusive of the Architects fees. The amount received from the War Damage Commission ${ }^{175}$ was $£ 605 . I 4.0 d$, and so the cost to the Trust had been only approximately $£ 45 \cdot{ }^{176}$

II. It was reported by the Hon Treasurer that Mr A.M. Khan was appointed Caretaker with effect from 6 May 1947 with the usual salary of $\mathcal{E}^{2.17}$.od a week.

\footnotetext{
${ }^{173}$ The Aga Khan's annual contribution of $\mathcal{E}_{150}$ began in 1943. See ELM Archives, Woodhead to the Aga Khan, I4 February 1948.

${ }^{174}$ Woodhead requested the Aga Khan to continue his annual donation (ibid).

${ }^{175}$ The War Damage Commission was set up by the government to deal with war damage compensation.

${ }^{176}$ The Jamiat-ul-Muslimin contributed $f_{2} 200$ towards the repairs. See ELM Archives, Woodhead to S.M. Jetha, 25 February $194^{8}$.
} 
With a vote of thanks to the Chairman and to the Hon Treasurer the meeting terminated.

\section{Royal Egyptian Embassy}

\section{LONDON}

I. I do hereby agree to the re-appointment of Sir Torick Ameer Ali as a Trustee to the London Mosque Fund with effect from I5 August 1947 .

2. I do hereby agree to the appointment of the following persons as Trustees of the London Mosque Fund:-

Mr. Hatim Attari

Mr Fazal Shah ${ }^{177}$

Mr Ghulam Mohammed

Signed:

The Aga Khan

Royal Egyptian Embassy

LONDON

I. I do hereby agree to the re-appointment of Sir Torick Ameer Ali as a Trustee to the London Mosque Fund with effect from I5 August 1947 .

2. I do hereby agree to the appointment of the following persons as Trustees of the London Mosque Fund:-

Mr. Hatim Attari

Mr Fazal Shah

Mr Ghulam Mohammed

Signed:

Hassan Nachat

Jumalek, Cairo

24 February 1948

Witness: J Baradon (Private Secretary)

3 Saidi Street, Soliman Pacha Sq, Cairo

\footnotetext{
${ }^{177}$ Syed Fazal Shah was the brother of Said Amir Shah (see above, p. 194) and one of the directors of their firm, Shah Bros. Ltd.
} 


\section{Minutes of the Meeting of the Trustees of the London Mosque Fund held on 23 September 1948 at the Royal Egyptian Embassy 75 South Audley Street London Wr}

\section{Present:}

Judge Waris Ameer Ali, G.I.E (in the Chair)

Sir Torick Ameer Ali

Hatim Attari Esq

Ghulam Mohammed Esq

An apology for absence was received from Lord Winterton.

I. The Minutes of the Meeting held on 5 February 1948 were confirmed.

2. On the proposal of Sir Torick Ameer Ali, seconded by Mr Hatim Attari, the audited accounts for the year ending 3r March 1948 were passed.

3. The appointment of Messrs. Feasey, Hull and Feasey as Auditors for the year $1948-49$ was approved and the Hon Treasurer was asked to thank them for their services during the year $1947^{-4} 8$.

4. It was recorded that Dr Hassan Nachat Pacha would cease to be a Trustee with effect from 30 September 1948. Dr Hassan Nachat Pacha had expressed a desire to resign prior to the meeting held on 5 February 1948, but at the request of the Trustees had agreed to remain a Trustee until zo September I948.

5. It was recorded that His Highness the Aga Khan had very kindly agreed to continue his donation of $\oint_{1}$ I 0 a year to the funds of the Trust during his lifetime. ${ }^{17^{8}}$ The Trustees were extremely grateful to His Highness and noted that the Hon Treasurer had already conveyed to His Highness the thanks of the Trustees.

6. The appointment of Mr Yusuf Nazeer as Caretaker with effect from 26 April 1948 was confirmed. It was noted that Mr Nazeer had agreed to serve without a salary. He would however, like his predecessors, be provided with free quarters, electricity and gas.

7. The draft Memorandum and Articles of Association of the East London Mosque Trust Limited ${ }^{179}$ were examined and generally

\footnotetext{
${ }^{17} \mathrm{~S}$ See his note communicating his agreement to this effect, ELM Archives.

${ }^{179}$ Copy not kept with the Minutes.
} 
approved. The following decisions were taken on the following points:

a) The proposed Trust Corporation should not include the Indigent Moslem Burial Fund. No difficulties had been experienced in the working of this fund and it was considered to be undesirable to complicate the formation of the Trust Corporation for the Mosque Fund by including the Indigent Moslem Burial Fund.

b) The first Members of the Trust:

i) Judge Waris Ameer Ali did not desire to be a Member, chiefly on the grounds of his health. This was reluctantly agreed to.

ii) It was felt that Lord Winterton would not desire to be a Member. At the meeting of 5 February 1948 he had expressed his desire not to be a Member.

iii) It was hoped that $\mathrm{HH}$. the Aga Khan would agree to be a member.

iv) The first Members of the Trust would therefore be: $:^{180}$

The High Commissioner for Pakistan.

The Ambassadors of Egypt and Saudi-Arabia.

The President of The Jamiat-al-Muslimin

95 Avenue Road

Penge

$\mathrm{SE}_{20}$

9 October 1948

Dear Sir John Woodhead

I am indebted to you for your kind letter dated 6 October I948. In reply, I confirm my agreement to serve under all the three heads mentioned in para " 4 " of your letter and hope to discharge my duties to the best of my ability.

Here allow me to point out that my surname and not title is Kazi.

To put it in Arab phraseology (by the by the people that introduced the custom of surnames in the west) Kazi is my surname and not a title. To obviate future confusion you will be pleased to address me as Imdad. I. Kazi.

${ }^{180}$ The ELM Archives contains details of names and dates. 
As to the title, I have none; unless you graciously allow an antiquated one to pass current. Under the act 3 of Queen Elizabeth of blessed memory, all the members of the Inns of Court are entitled in their personal right to the address as Esquires.

You will pardon me mentioning this, because change of name will create confusion not only with my bankers, but my wife's and my publishers as well.

Apologising for a lengthy letter, I remain

Yours sincerely

I.I. Kazi*

Hotel Ritz

Place Vendome

Paris

II October 1948

Dear Sir John

Thank you for your letter of 5 October.

I will be glad to become a member of the Trust Corporation.

Yours sincerely

Aga Khan

Shillinglee Park Chiddingfold

Hon Treasurer

London Mosque Fund 26 South Street

London $\mathrm{W}_{\mathrm{I}}$

I3 October 1948

Dear Sir John

I am sorry not to have answered your letter before owing to pressure of work.

In regard to the project for the re-organisation of the Fund, it seems to me to be excellent.

I presume that the change is quite legal or that, if there is any doubt about its legality, steps have been taken to have expert advice. 
I only mention this because I should not like, as a Trustee of the present Fund, to be involved in any litigation over the matter.

Yours sincerely

[signature not legible $]^{181}$

\section{L'Ambassadeur de S.M. le Roi D'Egypt \\ Londres}

\section{South Audley Street}

WI

I5 October $194^{8}$

Ref: 2933/21/I8/I3 B

Dear Sir John

I have received your letter dated I 3 th instant regarding the formation of a Trust Corporation of the East London Mosque at No. 446 Commercial road, EI.

I am writing to inform you that I shall be pleased to become, as Egyptian Ambassador, a member of the Trust and of the Council of Management of the said Trust, but, owing to pressure of work, Mr. A.L. Fahmy, Secretary of this Embassy, will represent me on the Council of Management whenever I am unable to attend.

As to the Chairmanship of the Council, I wish to say that I am in agreement with nominating the High Commissioner of Pakistan for that post, for the reasons put forward in your letter.

Yours sincerely

[signature]

Ambassador

\footnotetext{
${ }^{18}$ Shillinglee Park at Chiddingfold near Horsham in Sussex was the Winterton family seat (see http://www.horshamsociety.org/history/winterton.htm (accessed I9January 20Io)). It is therefore reasonable to conclude that this letter was from Lord Winterton, even though the signature is not legible.
} 
Norton, Rose, Greenwell \& Co I 6 Old Broad Street

London $\mathrm{EC}_{2}$

Dear Sir John

I3 December 1948

Sir John Woodhead G.C.E.E, K.C.S.I

Chevremont

Hockering Road

Woking

Surrey

\section{Re: East London Mosque}

Thank you for your letter of the i th instant giving me the information in regard to the three officers of the Jamiat-ul-Muslimin. I will now put in hand the preparation of the proof prints of the Memorandum \& Articles of Association.

Yours sincerely

[signature]

Norton, Rose, Greenwell \& Go i 6 Old Broad Street

London $\mathrm{EC}_{2}$

3I December 1948

Sir John Woodhead G.C.E.E, K.G.S.I

Chevremont

Hockering Road

Woking

Surrey

Dear Sir John

$\underline{\text { Re: East London Mosque Trust Ltd }}$

I now enclose three proof prints of the Memorandum and Articles of Association of the above proposed Company ${ }^{182}$ in order that you may go through the same yourself and may show it to the Trustees. Perhaps you would be good enough particularly to check the spelling

\footnotetext{
${ }^{182}$ See Appendix II for the text of this document.
} 
of the various names and that the right persons are shown as being first members of the Trust and first members of the Council respectively.

You will note that there are certain typographical errors in the proof which have been altered in ink, and when you let me hear that the proof is otherwise in order, I will have clean prints made for signature by the subscribers.

With best wishes for the New Year

Yours Sincerely

[signature]

Dear Sir

Pollingfold

Rudgwick

Suffolk

8 January $195^{\circ}$

I shall not be able to attend the meeting on Io January owing to being unwell. Please give my apologies to the chairman.

Yours

Torick Ameer Ali

\section{Minutes of the Meeting of the Trustees of the London Mosque Fund held on Io January 1950}

Present:

Waris Ameer Ali Esq. C.I.E (in the Chair)

Hatim Attari Esq

Syed Fazal Shah Esq

Ghulam Mohammed Esq

Sir John Woodhead, Hon Treasurer

An apology for absence was received from Sir Torick Ameer Ali. 
I. The minutes of the meeting held on 23 September 1948 were read and confirmed.

2. The appointment of Mr Jamil Fazaldin as Caretaker of the Mosque with effect from 20 October 1949 was confirmed. It was noted that Mr Fazaldin receives no salary but is provided with free quarters and gas and electricity free of charge.

3. The audited accounts for the year ending 3I March 1949 were approved and signed by the Chairman (Waris Ameer Ali Esq) and by the Hon Treasurer.

4. The appointment of Messrs Feasey, Hull and Feasey as Auditors for the year ending 3I March I950 was approved.

5. Sanction was accorded to the expenditure during the years ending 3I March I948 and 31 March 1949 amounting to

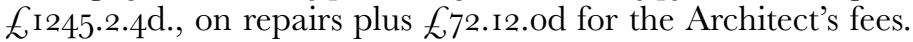
It was noted that $\mathcal{E}^{6} 605$.I4.od has been recovered from the War Damage Commission; this amount was made up of $£ 575$. I4.od on account of repairs and $£ 30$ for Architect's fees. The Jamiat-ul-Muslimin had also contributed $£_{2} 200$ towards the expenditure. The Committee placed on record their great appreciation of the generous contribution made by the Jamiatul-Muslimin.

6. Approval was given to the approximate expenditure of $\mathcal{E}_{3} 08$ which had been incurred on repairs to the shop in $45^{\circ}$ Commercial Road. The Hon Treasurer explained that the original estimate was $£_{1} 8_{3}$ of which it was estimated $£_{1} 5^{\circ}$ would be recoverable from the War Damage Commission. Unfortunately, when the work was started it was found that the old timber structure holding up the front basement wall and over the shop was rotten. The additional expenditure on this account has been estimated at f, I25 bringing that total to $£ 308$. The work had been carried out but the bills had not as yet been received from the Architect and payment had not therefore as yet been made.

7. Approval was given to the letting of the shop and back room in $45^{\circ}$ Commercial Road to the Caretaker, Mr Jamil Fazaldin, at a weekly rental of $30 / \mathrm{od}$., plus the general rates payable on account of the shop and back room, with effect from I4 October I949.

8. The Hon Treasurer reported that the premises $446-45^{\circ}$ Commercial Road had been insured with the Guardian 
Assurance Co. for a total value of $£ 7400$ plus $£ 400$ rent charge. The previous insured value was $£ 555^{\circ}$ plus $£ 400$ rent charge. The value had been increased because of the general rise in the value of property. This increase in the insured value was approved.

9. The Hon Treasurer reported on the progress made in the reorganisation of the Trust by the promotion of the East London Mosque Trust Corporation Ltd. It was explained that when the Trust Corporation has been formed it was found that owing to a recital in the purchase deed of the property, it would be necessary to obtain the approval of the Charity Commissioners. It was hoped that this approval would shortly be received and it would then be possible to proceed with the execution of the documents for the transfer of the property and securities from the Trustees to the Trust Corporation. The re-organisation would then be complete.

Io. Consideration was given to letter ACF/LMC of 4January I950 from the Auditors. It was decided to write off the two sums mentioned in that letter, viz:

a) an item of $£$ I7.I0.od. This is a book entry from the Mosque Fund and the Mosque and Culture Centre in Commercial Road

b) a small debt of $4 / 9 \mathrm{~d}$ due to the Trustees which had been shown for many years as outstanding.

W. Ameer Ali I3 February I95 I

\section{Gircular}

The shop and back room at No $45^{\circ}$ Commercial Road were let to Jamil Syed Aladin Fazaldin, the Caretaker, at a rent of EI.Io.6 a week plus the rates, $15.5 \mathrm{~d}$. a week, with effect from 14 October I949.

A shop takes some time to become established and I am satisfied that for the present, at any rate, the above rent is more than Fazaldin can afford to pay. I have visited the shop fairly regularly and formed the impression about six weeks ago that the rent was on the high side, but postponed a final conclusion until more experience had been gained. I am now convinced that the rent should be reduced. 
I propose that the rent be reduced to $£$ i.o.od., a week, plus the rates (I5/5d) a week, with effect from I4 October 1949 and that the reduced rent be fixed for twelve months, until I4 October I950 when it will be brought under review.

It will be recalled that the Caretaker is not in receipt of any salary. It is convenient to have the shop let to the Caretaker, for it means that he is practically always available at the Mosque.

J. A. Woodhead
Hon Treasurer.

[not dated but probably 4 April 1950]

$\mathrm{I}_{55} 6$

Good Friday I950

My dear Sir John Woodhead

Ref enclosed circular I agree entirely with your proposal to reduce the rent of the shop and back room to $\mathcal{E}_{\mathrm{I}}$ a week plus rates. As you very rightly point out, if I may say so, the lessee works for the Mosque Fund as caretaker without a salary and his shop takings are probably precarious too. Furthermore we can review the rent as you say on I4 October. Do we have to vary an agreement or anything?

Can we job up the solicitors who are dealing with the new body for the Trust in any way? Let me wish you a Happy Easter, and believe me

Very sincerely

Waris Ameer Ali

Do pray let me know some time you are coming to London.

GHULAM MOHAMMED

59 Canton Street London EI4

\section{Dear Sir}

I agree with your proposal regarding the reduction of rent at No $45^{\circ}$ Commercial Road from 30/- per week to $\mathcal{E}_{\mathrm{I}}$, plus rates $\mathrm{I}_{5} / 5$ which take effect from Oct I4 I949-Oct I4 I950.

Ghulam Mohammed (Trustee) 
Ig Berkeley Street WI

\section{$\mathrm{HA} / \mathrm{EP}$}

Dear Sir John

Mr Wise sent me a notice as regards the rent of the shop at No. $45^{\circ}$ Commercial Road, and I am in agreement with your proposal therein.

With kindest regards

Yours Sincerely

Hatim Attari

Pollingfold

Rudgwick, Sussex

London Mosque Fund

8.4 .50

Dear Sir

Your letter of $4 \cdot 4 \cdot 5$. I quite agreed to this proposal.

Yours

Torick Ameer Ali

244 Bilton Road

Perivale

Middlesex

2I April i950

Sir John Woodhead

East London Mosque Trust

26 South Street

W I

\section{Dear Sir}

In the absence of Mr Syed Fazal Shah, who is in Pakistan at the present, I have opened your letter addressed to him dated I8 April. 
$\mathrm{Mr}$ Shah will be pleased to reply to your letter as soon as he returns from Pakistan.

Yours Faithfully

B.H Shah

\section{Minutes of a Meeting of the London Mosque Fund held on Tuesday February I3 I95I at the Royal Egyptian Consulate General, 26 South Street, London WI}

Present:

Lord Winterton (in the Chair)

Judge Warish Ameer Ali

Mr Hattim Attari

Apologies for absence from Mr Ghulam Mohammed, Sir Torick Ameer Ali

I. The Minutes of the Meeting held on January io I950 were confirmed and signed.

2. The audited accounts for the year ending March 3I I950 were passed and signed by the Chairman and Hon Treasurer.

3. It was resolved that Messrs. Baker, Todman and Co., be appointed Auditors for the year ending March 3I I95I.

4. The Hon Treasurer reported that the final bill for the repairs to the shop in $45^{\circ}$ Commercial Road amounted to £320.I2.9. against an estimate of $£ 3$ o8.o.o. approved at the last Meeting. The small increase is accounted for by the cost of painting the internal walls which was not included in the original estimate. When the original estimate was prepared, the architect estimated that I5 0.0.o would probably be recovered from the War Damage Commission. The final amount recovered is, however, only f92.o.o., the highest figure to which the approval of the War Damage Commission could be obtained. Sanction was given to the payment of the final bill less the amount received from the War Damage Commission. 
5. The payment of the following amounts as fees to the architect, Mr Alister MacDonald were approved:

E30.6.o on account of the work in connection with the shop $£ 25$.o.o on account of other work carried out to the premises $44^{6 / 45^{\circ}}$ Commercial Road.

It was noted that of the sum of $£ 3$ o.6.o., the sum of $£$ I3 3 .Io.o had been recovered from the War Damage Commission.

6. Sanction was given to the following expenditure on repairs to the property during the year $195^{-}{ }^{-} 5^{\mathrm{I}}$.

\section{Aldgate Building Company}

Bill dated April I5 I950 amounting to f26.Io.o., for repairs to the roof.

Bill dated August 25 I950 amounting to fiog.io.o on account of internal decoration and miscellaneous repairs.

Bill dated February 2 I95I amounting to £28.o.o., on account of further repairs to the roof.

7. Sanction was given to the expenditure of $£ 20.0 .0$ to be incurred on the installation of two power points and minor repairs to the electricity installation.

8. Approval was given to the installation in the caretaker's quarters of an Ascot gas heater at a cost of Ei6.i6.o.

9. The Hon Treasurer reported that Mr Alladad Khan had agreed to take the four rooms on the first and second floors of $45^{\circ}$ Commercial Road at a rent of 30 s a week including rates. Sanction was given to the letting of these four rooms at the proposed rent and on the conditions in the Hon Treasurer's letter dated February 2 I95I.

Io. The Hon Treasurer reported on the progress made in the promotion of the Trust Corporation. He explained that the delay had been due to the long time taken by the Charity Commissioners in preparing a scheme. This scheme had been received towards the end of $195^{\circ}$ and the necessary notices had been issued. The solicitors were now awaiting the final scheme from the Charity Commissioners. When this had been received, it would be possible to proceed with the execution of the documents transferring the securities held by the present trustees and the property at 446-450 Commercial Road from the existing trustees to the Trust Corporation. Lord Winterton 
proposed and the other trustees agreed that it would be desirable, when the re-organisation was complete, for the Solicitors to write a letter to the trustees informing them that their responsibility for the Trust Fund had ceased.

II. The Meeting closed with a vote of thanks to the Hon Treasurer and the Chairman.

\section{The East London Mosque Trust Limited}

\section{Minutes of the First Meeting of the Council of Management held at 446/448 Commercial Road, London. E.I on 2 I December 195 I}

Present:

H.E Habib I Rahimtoola, ${ }^{*}$ High Commissioner for Pakistan Dr H.H. Bilgrami*

M.S Manawar Hossain ${ }^{* 183}$

Sir John Woodhead, Secretary

I. The Certificate of Incorporation of the Company dated II May I949, together with a print of the Memorandum and Articles of Association of the Company as registered were produced.

2. IT WAS RESOLVED that Sir John Woodhead, G.C.I.E, K.C.S.I. having acted as Secretary of the Company since its incorporation, his appointment be and it is hereby confirmed. It was reported that the necessary Notice of Sir John's appointment had been filed with the Registrar of Companies.

3. IT WAS RESOLVED that the situation of the Registered Office of the Company be at 446/448 Commercial Road, East I, and it was reported that Messrs. Norton, Rose, Greenwell Co. had filed the necessary Notice with the Registrar of Companies together with Particulars of the Council of Management of the Company, being the Directors named in Article I8 (B) of the Company's Articles of Association. The Secretary was given instructions to have the name of the Company painted

\footnotetext{
${ }^{18}$ Mohammed Saiyid Manawar Hossain (sometimes spelt Hosain, Hussain).
} 
or affixed on the outside of the Registered Office and to have the Certificate of Incorporation framed and hung up at the office.

4. IT WAS RESOLVED that Barclays Bank Ltd. (I40-I42 Commercial Road, E.I) be appointed Bankers of the Company. That the said Bank be and they are hereby authorised:

I. To honour and comply with all Cheques Drafts Bills Promissory Notes Acceptances negotiable instruments and orders expressed to be drawn accepted made or given on behalf of this Company at any time or times whether the banking account or accounts of the Company are overdrawn by any payment thereof or in relation thereto or are in credit or otherwise.

2. To honour and comply with all instructions to deliver or dispose of any securities or documents or property held by the Bank on behalf of the Company.

Provided any such Cheques Drafts Bills Promissory Notes Acceptances negotiable instruments orders and instructions are signed by any one member of the Council of Management and countersigned by the Secretary.

3. To treat all Cheques Drafts Bills Promissory Notes Acceptances negotiable instruments and orders as being endorsed on behalf of the Company and to discount or otherwise deal with them provided such endorsements purport to be signed by any one member of the Council of Management or by the Secretary.

And that a copy of the forgoing Resolution be forwarded to the Bank by the Secretary, together with specimen signatures of the present Members of the Council and Secretary.

IT WAS FURTHER RESOLVED that the Trustees of the London Mosque Fund be requested to transfer the balance standing to the credit of the account of that Fund with the Bank of England to the company's Account with Barclays Bank Limited.

5. IT WAS RESOLVED that Messrs. Baker, Todman and Co., of Canada House, Norfolk Street, London, W.C.2 be and they are hereby appointed Auditors of the Company and that until the Annual General Meeting of the Company to be held in 
the year 1952 their remuneration should be arranged by the Board.

6. A Common Seal which had been prepared for the Company was produced and IT WAS RESOLVED that the same be and is hereby adopted as the Common Seal of the Company, and that an impression thereof be made in the margin of these Minutes in the presence of one of the Members of the Council.

7. IT WAS REPORTED that fifty prints of the Memorandum and Articles of Association of the Company, together with the necessary registers and books required by the Company, had been ordered and such orders were approved and confirmed.

8. IT WAS RESOLVED that all securities, stock and share Certificates and other documents of title from time to time belonging to the Company and not required for our rent purposes be deposited in the name of the Company with the Company's Bankers, and that all orders for delivery out by the Bankers be signed by any two Members of the Council, pursuant to a resolution of the Council to that effect.

9. It was reported that the Charity Commissioners, by an Order dated the 9 March I95I, had approved and established a Scheme whereby it was provided that the London Mosque Fund and the endowments thereof should be administered and managed by the Company, which should be the Trustee of the Charity and take the place of the Executive Committee and the Trustees. Such Order further provided that the land and buildings at $44^{6}$, 448 and $45^{\circ}$ Commercial Road should vest in the Company. It was further reported that in pursuance of such an Order the Company had been placed on the Register at the Land Registry in respect of the Commercial Road property.

Io. There were produced transfers in favour of the Company of the under-mentioned securities held on behalf of the Fund by Syed Waris Ameer Ali, the Right Honourable Edward Earl Winterton, Sir Torick Ameer Ali, Hatim Attari, Syed Fazal Shah and Ghulam Mohammed:

$$
\begin{array}{ll}
\AA^{2,500} & 3 \frac{1}{2} \text { Conversion Stock } \\
\mathcal{L}^{\mathrm{I}, \mathrm{OOOO}} & 3 \% \text { Savings Bonds, I96o-70 } \\
£ 4, \mathrm{II} 3 \cdot 3 \cdot 7 & 3 \% \frac{\mathrm{I}}{2} \% \text { War Stock }
\end{array}
$$


Such transfers being duly executed by all the above named gentlemen with the exception of Syed Fazal Shah who is now deceased. ${ }^{184}$ IT WAS RESOLVED that the Seal of the Company be affixed accordingly. IT WAS FURTHER RESOLVED that such transfers be handed to Messrs. Norton Rose Greenwell \& Co. in order that they could lodge the same with the Bank of England for registration and obtain new Certificates in the name of the Company. IT WAS FURTHER RESOLVED that Dividend Request Forms in favour of Barclays Bank, Commercial Road, E.I, be sealed by the Trust's Seal and the same be lodged with the Bank of England along with the transfers.

II. It was reported that the above formalities having been completed, the Company was now in a position to administer the trusts of the London Mosque Fund.

I2. It was proposed by Dr Bilgrami and seconded by Mr Manawar Hosain that H.E.H.I. Rahimtoola be elected Chairman of the Council. Carried unanimously.

I3. It was proposed that Dr H.H. Bilgrami and seconded by H.E.H.I. Rahimtoola that Mr S. Manawar Hossain be elected Vice Chairman of the Council. Carried unanimously.

I4. It was proposed by H.E.H.I. Rahimtoola and seconded by Dr H.H. Bilgrami that Mr Suleman M. Jetha* be appointed a member of the Council in the vacancy caused by the death of Mr Syed Fazal Shah. Carried unanimously.

I5. It was proposed by H.E.H.I. Rahimtoola and seconded by Dr H.H. Bilgrami that Mr Suleman N. Jetha be appointed Hon Treasurer. Carried unanimously.

I6. IT WAS RESOLVED THAT Mr Sadiq Hassain Kazmi ${ }^{185}$ having been proposed by Dr H.H. Bilgrami and seconded by Mr S. Manawar Hosain and having completed the prescribed application form be admitted a member of the East London Mosque Trust Ltd.

\footnotetext{
${ }^{184}$ Reported by the Trust's solicitors, Norton, Rose \& Greenwell Co. in their letter of 28 August 195I, ELM Archives.

${ }^{185}$ Probably the nephew of Mohammed Saiyid Manawar Hossain.
} 
Application for Membership of the East London Mosque

Trust Ltd

(prescribed by the Council under Article 5 of the Articles of Association)

I of...

hereby apply to be admitted a member of the East London Mosque Trust Ltd. I declare that I am of the Moslem faith and am interested in and am willing to contribute to, or actively to further the objects of the Trust as set forth in the Memorandum of Association.

I undertake to further to the best of my ability, the objects and interests and influence of the Trust and at all times to observe the Regulations of the Trust.

I also undertake from time to time to notify to the Secretary of the Trust a place of business or residence to be registered as my place of address and the place so registered shall for the purpose of the Regulations of the Trust be deemed to be my place of address.

Sd.

\section{The East London Mosque Trust Limited}

\section{Annual General Meeting held at 448 Commercial Road on} 2I December I95I, at 3.45 pm

Present:

H.E.H. I. Rahimtoola (in the chair)

Dr H.H. Bilgrami

Mr Suleman M. Jetha

Mr S. Manawar Hosain

Mr Sadiq H. Kazmi

I. The Secretary read the notice convening the Meeting.

2. The Secretary reported that no Accounts were available for submission to the Members as, owing to various formalities having to be dealt with, it had only been possible for the Trust 
Company to take over the Trusts of the London Mosque Fund that day.

3. The Secretary reported that, pursuant to the provisions of Article I8 (C) (iii) Sir Torick Ameer Ali, Mr Hatim Attari, Mr Ghulam Mohammed Khan, Mr Imdad Ali Imam Ali Kazi and Mr Suleman M. Jetha retire from their office as Members of the Council, but that Mr Hatim Attari, Mr Ghulam Mohammed Khan, Mr Imdad Ali Imam Ali Kazi and Mr Suleman Jetha, who had indicated their willingness to be re-elected were eligible for re-election.

4. It was resolved (i) on the proposal of Dr Bilgrami and seconded by H.E.H.I Rahimtoola that Mr Hatim Attari, Mr Imdad Ali Imam Ali Kazi, Mr Ghulam Mohammed Khan, Mr Suleman Mohomed Jetha be elected members and (ii) on the proposal of Mr S Manawar Hosain and seconded by Mr Suleman M Jetha that Mr Sadiq Hussein Kazmi be elected members [sic] of the Council of Management.

A hearty vote of thanks was passed to H.E.H.I. Rahimtoola for presiding at the meeting, to Sir John Woodhead for all the work he had done in connection with the reorganisation scheme and to Messrs. Norton, Rose, Greenwell \& Co., the Solicitors, who had carried through so successfully the creation of the East London Mosque Trust Ltd. 